\title{
Characterization of KNDy Neuronal Activity in Gilts: Distribution and Effect of A Progestin
}

\author{
Ashley Nicollette Lindo
}

Follow this and additional works at: https://researchrepository.wvu.edu/etd

\section{Recommended Citation}

Lindo, Ashley Nicollette, "Characterization of KNDy Neuronal Activity in Gilts: Distribution and Effect of A Progestin" (2018). Graduate Theses, Dissertations, and Problem Reports. 6093.

https://researchrepository.wvu.edu/etd/6093

This Thesis is protected by copyright and/or related rights. It has been brought to you by the The Research Repository @ WVU with permission from the rights-holder(s). You are free to use this Thesis in any way that is permitted by the copyright and related rights legislation that applies to your use. For other uses you must obtain permission from the rights-holder(s) directly, unless additional rights are indicated by a Creative Commons license in the record and/ or on the work itself. This Thesis has been accepted for inclusion in WVU Graduate Theses, Dissertations, and Problem Reports collection by an authorized administrator of The Research Repository @ WVU. For more information, please contact researchrepository@mail.wvu.edu. 
Characterization of KNDy Neuronal Activity in Gilts: Distribution and Effect of A Progestin

Ashley Nicollette Lindo

Thesis submitted to the Davis College of Agriculture, Natural Resources and Design at West Virginia University

in partial fulfillment of the requirements for the degree of

Master of Science

in

Reproductive Physiology

Stanley M. Hileman, Ph.D., Chair

Robert L. Goodman, Ph.D.

Clay A. Lents, Ph.D.

Department of Animal Science

Morgantown, West Virginia

2018

Keywords: gilt, puberty, KNDy, kisspeptin, Altrenogest, neurokinin 3 receptor, NKB Copyright 2018 Ashley Nicollette Lindo 


\section{ABSTRACT \\ Characterization of KNDy Neuronal Activity in Gilts: Distribution and Effect of A Progestin}

\section{Ashley Nicollette Lindo}

Puberty is a process that incorporates a large array of both external factors and internal signals. The endocrinology of puberty has been studied in a number of mammalian species and typically depends upon an increase in hypothalamic secretion of gonadotropin releasing hormone $(\mathrm{GnRH})$. Neural inputs regulating GnRH secretion during the pubertal process are not completely understood. In the past decade, attention has focused on the role for a particular set of neurons located in the arcuate nucleus (ARC) of the hypothalamus. They have been named KNDy neurons because they coexpress kisspeptin, neurokinin B (NKB) and dynorphin and have been shown to stimulate (kisspeptin, NKB) or inhibit (dynorphin) GnRH and luteinizing hormone (LH) secretion. While KNDy neurons have been studied extensively in primates, rodents, and sheep, almost nothing is known about this system in porcine, a species of significant agricultural importance. Our studies describe an initial foray into characterizing this system in the porcine hypothalamus. We first determined that, similar to other species, kisspeptin was expressed in the ARC and that $\mathrm{NKB}$ and kisspeptin were coexpressed in this region to a very high extent. We then examined the distribution of receptors for NKB (NK3R) and found them to be expressed in the preoptic area (POA) and several areas of the hypothalamus, including the paraventricular nucleus $(\mathrm{PVN})$ and retrochiasmatic area $(\mathrm{RCh})$. However, there was no evidence of NK3R expression in the ARC. The NK3R-positive cells found in the POA did not co-localize with GnRH but expressed close contacts with GnRH neurons. We then used gilts that were ovariectomized (OVX) or OVX and treated with Altrenogest (OVXA), a progestin, to test the hypothesis that Altrenogest would suppress kisspeptin and NKB immunopositive cell numbers in the ARC and NK3R-positive cell numbers throughout the hypothalamus. Surprisingly, kisspeptin containing cell numbers tended to be increased $(\mathrm{p}=0.09)$ in in OVXA gilts $(\mathrm{n}=6)$ compared to their OVX, untreated counterparts $(n=6)$. In addition, there was no significant change in NKBpositive cell numbers in response to Altrenogest. Subsequent analysis determined a tendency ( $p$ $=0.08$ ) for a decrease in the percentage of kisspeptin neurons expressing $\mathrm{c}$-Fos, a marker of neural activation, in OVXA versus OVX gilts. There was no effect of Altrenogest on NK3Rpositive cell numbers in any area. These studies mark one of the first investigations into the KNDy system in swine. Many of the characteristics examined here are similar to that previously reported for other mammalian species, with the notable exception of an absence of NK3R expression within the ARC. Treatment with a progestin did not suppress kisspeptin or NKB expression but did tend to reduce activity of kisspeptin neurons. These results suggest that, similar to other species, KNDy neurons likely play an important role in regulating reproduction in swine. 


\section{DEDICATION}

I dedicate this thesis to my entire support system of family and friends. I give the greatest thanks to my parents, Dara and Horacho Lindo, for always making sacrifices to provide their children with best life possible whilst being my pillars of support since the very beginning. I also owe an enormous thanks to my brother, Horatio, and my sister, Alexis, for teaching me right from wrong throughout our childhood and never letting a sibling fight stop them from doing everything they can to help me succeed. 


\section{ACKNOWLEDGEMENTS}

First and foremost, I give thanks to Dr. Stanley Hileman and Dr. Robert Goodman for being extraordinary mentors and educators throughout my graduate career. They have supplied endless knowledge and guidance that allowed me to succeed in my academics as well as the process of writing my thesis. I am also thankful to Dr. Clay Lents for agreeing to serve on my committee, supplying the samples for my research and responding to my many questions regarding my experiment. Special thanks to Dr. Jennifer Fridley and Dr. Margaret Minch for providing priceless animal surgery and veterinary experience that increased the breath of information I have received from this program. To Dr. Keith Inskeep, thank you for believing in me, being an unmatched resource and a genuine individual who always had my best interest at heart.

Additionally, I would not have been able to succeed these past few years without my colleagues and close friends here at WVU. Huge thanks to my best friend and main support, Jordan Wilson. Thank you, Dr. Michelle Bedenbaugh for basically teaching me every scientific technique I know and for never getting annoyed with the amount of questions I asked you every single day. Thank you to Justin Lopez, Dr. Lizzie Bowdridge and Dr. Rick McCosh for your advice, laboratory help and constant supply of humorous distractions throughout the day. Thanks also to Denzel Middleton for being an excellent best friend, president to my vice-president and study buddy. Last but certainly not least, thank you to Samantha Young and Lanny Meadows for your contributions to this research and Dr. Miro Valent and Gail Nesselrod for technical help and always taking a minute to ask me how I am doing.

I am forever grateful to every and anyone who was a part of my support system during this time. Thank you all. 


\section{TABLE OF CONTENTS}

ABSTRACT_

DEDICATION __ iii

ACKNOWLEDGEMENTS ___ iv

TABLE OF CONTENTS___V

LIST OF FIGURES__ vii

LIST OF TABLES___ ix

LIST OF NOMENCLATURE___ $\mathrm{X}$

CHAPTER I: INTRODUCTION___ 1

CHAPTER II: REVIEW OF LITERATURE__ 5

Characterizing Reproduction ___ 5

HPG Axis _ 5

GnRH Neuron Development___ 5

Pattern of GnRH Release __ 7

GnRH Pulse Generator___ 8

GnRH Surge Generation__ 11

Endocrinology of Puberty Onset____ 15

Estrogen Feedback and the LH Surge __ 15

Other Important Factors___ 16

Back Fat/Body Composition and Growth Rate___ 17

Leptin — 19

The Estrous Cycle of the Pig___ 21

Phases___ 21

Steroid Action and Feedback__ 24

KNDy neurons ___ 27

Introduction__ 27

Kisspeptin__ 27

Neurokinin B__ 30

Dynorphin__ 32

CHAPTER III: CHARACTERIZATION OF KNDY NEURONAL ACTIVITY IN GILTS: DISTRIBUTION AND EFFECT OF A PROGESTIN___ 36

Introduction __ 36

Materials and Methods ___ 37

Animals and Diets __ 37

Surgery and Treatments _ 38

Tissue Collection__ 39 
Tissue Analysis

Data Analysis

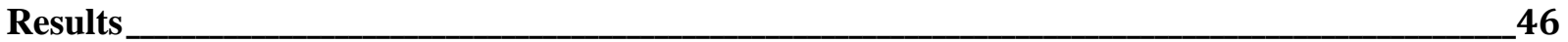

LH Data___ 46

Kisspeptin _ 49

$N K B \_52$

$N K 3 R \_54$

Discussion____ 58 


\section{LIST OF FIGURES}

Figure 1: Mean ( \pm SEM) concentrations of LH (A), LH inter-pulse interval (B), LH pulse amplitude (C), and LH pulse frequency (D) for OVX (blue bars) and OVXA (yellow bars) gilts. Asterisk indicates significance between groups $(\mathrm{p}<0.05)$.

Figure 2: Representative LH profiles for an OVX (top) and OVXA gilt (bottom). Asterisks indicate calculated LH pulses.

Figure 3: Representative micrograph of DAB stained kisspeptin cells within OVX ARC.

Figure 4: Mean (Avg) ( \pm SEM) kisspeptin-positive cells in the rostral, middle and caudal ARC of OVX and OVXA gilts. Different letters indicate differences between regions of ARC $(\mathrm{p}<0.05)$. Asterisk indicates differences between OVXA and OVX groups $(\mathrm{p}<0.05)$.

Figure 5: Mean ( \pm SEM) kisspeptin cell numbers within the ARC of OVX and OVXA gilts from replicate one (A) and replicate two (B). Number signs indicate a trend (p $=0.09$ ).

Figure 6: A 20x photomicrograph of ARC kisspeptin cells in the ARC with nuclear DAB/Nickel staining for c-Fos as an index of neuronal activation. White arrow heads point to kisspeptin cells that are positive for cFos staining; Black arrows point to kisspeptin cells lacking c-Fos staining.

Figure 7: Mean ( \pm SEM) NKB cell numbers in the ARC of OVX and OVXA gilts. Cell numbers were not statistically different.

Figure 8: Coexpression of kisspeptin and NKB in the ARC. Dual immunofluorescence (viewed at 60x) for two neurons in the ARC expressing kisspeptin (red, left panel) and NKB (green, middle panel). The merged image in the right panel clearly demonstrates colocalization of the two peptides.

Figure 9: Mean ( \pm SEM) NK3R-immunopositive cell numbers throughout the POA and hypothalamus in OVX gilts $(\mathrm{n}=3)$. Different letters indicate significance between regions $(\mathrm{p}<0.05)$.

Figure 10: Lack of NK3R coexpression with GnRH neurons. A representative photomicrograph of GnRH (green) and NK3R-containing (red) neurons using duallabel immunofluorescence in the POA of the pig hypothalamus (63x).

Figure 11: Top) A photomicrograph (63x) of NK3R immunopositive contacts (red, middle panel) on GnRH neurons (green, left panel) using dual-label immunofluorescence in the POA. In the merged image (right panel), white arrow heads point to close contacts. Bottom) The proportion of GnRH neurons in the POA closely apposed to NK3R Contacts. There was no difference between treatment groups.

Figure 12: Effect of Altrenogest on mean $( \pm$ SEM) NK3R-containing cell numbers 
in the PVN, RCh and POA. There was no significant difference in cell numbers between OVX or OVXA gilts for any area.

Figure 13: Photomicrographs (20x; right) and schematic drawings (left) of coronal slices through porcine POA and hypothalamus from OVX gilts representing the distribution of NK3Rcontaining neurons (solid circles). Note the lack of detectable staining with the ARC. ac, anterior commissure; ARC, arcuate nucleus; DBB, diagonal band of Broca; fx, fornix; mt, mammillothalamic tract; oc, optic chiasm; ot, optic tract; PVN, paraventricular nucleus; RCh, retrochiasmatic area; SON, supraoptic nucleus. 


\section{LIST OF TABLES}

Table 1: Diet composition, $\%$ as fed.

Table 2: Mean $( \pm \mathrm{SEM})$ numbers of kisspeptin and kisspeptin cells expressing nuclear cFos staining within the ARC of OVX and OVXA Gilts. There tended to be a lower percentage of activated kisspeptin neurons in OVXA compared to OVX gilts ( $\mathrm{p}=0.08$, indicated by the double asterisk). 


\section{LIST OF NOMENCLATURE}

AgRP, agouti-related peptide

ARC, arcuate nucleus

AVPV, anteroventral periventricular nucleus

CNS, central nervous system

COC, cumulus oocyte complex

ER-a, estrogen receptor alpha

EOP, endogenous opioid peptide

GnRH, gonadotropin-releasing hormone

HPGx, Hypothalamic-Pituitary-Gonadal Axis

IGF-1, insulin-like growth factor

ICV/i.c.v., intracerebroventricular

к-OR, kappa-opioid receptor

Kiss/Kiss1, kisspeptin

Kiss1r/GPR54, Kisspeptin receptor

KNDy, Kiss-NKB-DYN
LepR/Ob-R, leptin receptor

LH, luteinizing hormone

$\mathbf{L V}$, lateral ventricle

MBH, mediobasal hypothalamus

ME, median eminence

NK1R/NK2R/NK3R, tachykinin receptors

NKB, neurokinin B

NPY, neuropeptide Y

OVX, ovariectomized

POA, preoptic area

PVN, paraventricular nucleus

POMC, proopiomelanocortin

$\mathbf{R C h}$, retrochiasmatic area

SCN, suprachiasmatic nucleus

SON, supraoptic nucleus 


\section{CHAPTER I: INTRODUCTION}

Puberty is a complex event, the timing of which relies on the interplay of cues from genetic and environmental factors. There are many hormonal, physiological and physical changes that rely on the cascade of developmental events that lead to reproductive capacity [1]. Any combination of changes can delay or advance puberty onset and affect the reproductive development of an individual. In many mammalian species, activation of the hypothalamicpituitary-gonadal axis (HPGx), and more specifically an increase in the pulsatile release of gonadotropin releasing hormone ( $\mathrm{GnRH})$, is key to summoning the onset of puberty. Defining the neural mechanisms that control GnRH secretion is essential for understanding how puberty, as well as other reproductive activity, occurs. Thus, the totality of external and internal inputs must be transduced into information that stimulates an increase in the pulsatile release of GnRH. This could be due to increases in stimulatory input, decreases in inhibitory input, or more likely both. One thing that is clear in domestic livestock species (sheep, cattle, pigs) is that estradiol plays a central role. During the prepubertal period when GnRH and LH secretion is minimal, low levels of estradiol are produced by the ovaries and act in a negative feedback fashion to inhibit GnRH release [2]. As the individual grows and develops, estradiol negative feedback lessens [3], allowing for an increase in pulsatile $\mathrm{GnRH}$, and thus $\mathrm{LH}$, release. This increase in pulsatile LH secretion, in turn, stimulates further estradiol secretion which escalates over time until concentrations of estradiol reach levels sufficient to trigger the GnRH and LH surge and first ovulation [4-6]. Both are crucial for follicular development, ovulation and expression of estrous or menstrual cycles [7]. Importantly, native GnRH neurons do not express estradiol receptor alpha $(E R \alpha)$, the relevant estradiol receptor for mediating either positive or negative feedback of the steroid [8-10], so intermediary neurons must be involved in communicating estradiol 
feedback.

Currently, a group of neurons in the arcuate nucleus (ARC) of the hypothalamus are believed to play an important role in mediating this estradiol negative feedback. One of the peptides expressed by these neurons, kisspeptin, was recognized for its importance in reproduction when mutations of its receptor, GPR54, led to defects in fertility as well as hypogonadotropic hypogonadism in humans [11,12]. It was subsequently shown that kisspeptin neurons express ER $\alpha$ and that administration of kisspeptin stimulates LH secretion in virtually every mammalian species studied to date [13-18]. In 2007, it was observed that ARC kisspeptin neurons also coexpressed neurokinin $\mathrm{B}$ (NKB) and an endogenous opioid peptide (EOP), dynorphin, leading to the term "KNDy" neurons [19]. Similar to what has been observed for the kisspeptin receptor, mutations in the receptor for $\mathrm{NKB}, \mathrm{NK} 3 \mathrm{R}$, lead to disrupted fertility and hypogonadotropic hypogonadism in humans [20,21]. Both neuropeptides have been shown to stimulate GnRH and/or LH secretion in rats [22], primates [23] and sheep [24-26] with the actions of NKB being kisspeptin- and steroid-dependent [22,27,28]. Given this evidence, KNDy neurons have been suggested to play an important role in GnRH pulse generation $[29,30]$ with NKB acting locally by stimulating other KNDy neurons expressing NK3R to release kisspeptin [22]. Kisspeptin then acts via its receptor, GPR54 (also known as KISS1r), which is expressed on GnRH neurons, to initiate a pulse of GnRH. To extinguish this pulse, it is hypothesized that dynorphin acts to terminate NKB/kisspeptin release [29,31]. Although this gives a significant role to KNDy neurons in gonadotropin release, there is still much to be understood about their role in reproduction, especially as it concerns species to species variation [32]. While KNDy neurons have been characterized in several species, including sheep [19], rodents [33], goats [17], heifers [34] and primates [35], these neurons have been virtually unstudied in pigs. 
The importance for studying reproduction in pigs arises from the fact that pork is the leading meat consumed around the world and the pork industry is rapidly growing in developing countries [36,37]. This is in part due to the fact that swine are adaptable to many climates and can be used as a major food source in different environments [38]. Over time, pork production systems have moved from outside to indoor facilities to improve nutrition, growth, and reproduction, which has been aided in large part by technological advancements in pig housing. The increased control accompanying this form of swine management has led to an increase in farm size and better production rates. In addition, this more intense approach to management undoubtedly has positively affected the leading factor in determining pork producer profitability, the reproductive efficiency of sows [39]. However, gilts raised under total confinement conditions exhibit a delay in the onset of puberty compared with gilts raised under nonconfinement conditions [40]. In fact, one-third of gilts are culled from breeding herds due to a delay in the onset of puberty [41]. Gilts should reach puberty between 200-230 days of age (6-7 months) to minimize the total non-productive days (NPD) while increasing sow longevity and breeding herd efficiency [41-43].

Improvements in reproductive management and estrus detection have led to increased sow longevity and lifetime performance. As a result, U.S. farrowing rates increased $14.6 \%$ from 2001 to 2012 and pigs per litter steadily increased every year during that period [44]. In pigs, the efficiency of a breeding herd is directly correlated to the number of litters and litter size produced by the sow each year [45]. Nevertheless, although the importance of timely achievement of puberty by gilts is obvious, there is still much to be understood regarding the neural mechanisms regulating puberty onset and reproductive cyclicity in the pig.

This review will discuss research in the female pig, which we used for our experiments, 
but it will also borrow from findings in sheep, rodents and primates that explore the connection between KNDy neurons and reproduction. 


\section{CHAPTER II: REVIEW OF LITERATURE}

\section{Characterizing Reproduction}

\section{HPG Axis}

Reproduction is primarily controlled by the principal components of the HPGx. This axis is critical not only for onset of puberty, but also in regulating estrous and menstrual cycles. Within this axis, the hypothalamus serves as an integrating center that receives and coalesces information from gonadal and metabolic hormones to influence secretion of gonadotropin releasing hormone $(\mathrm{GnRH})$. $\mathrm{GnRH}$ then acts on gonadotropes in the anterior pituitary to cause the release of luteinizing hormone $(\mathrm{LH})$ and follicle stimulating hormone (FSH). These glycoprotein hormones stimulate gonadal steroid secretion which can have either inhibitory (estrogen, progesterone) or stimulatory (estrogen) feedback on GnRH release in females. Since $\mathrm{GnRH}$ is critical for reproduction and is the ultimate output from the hypothalamus as regards reproduction, this review will begin with a discussion of the history and biology of GnRH.

\section{GnRH Neuron Development}

In 1948, Geoffrey Harris presented evidence of hypothalamic control over pituitary secretions and further actions down the axis such as gonadal development and sexual behavior [46]. He hypothesized that the hypothalamus produced a humoral substance that could travel through the median eminence (ME) and affect the secretion of gonadotropins. Due to the development of more advanced technical approaches, this humoral factor was able to be isolated from both bovine and ovine species 16 years later [47]. The decapeptide was initially called mammalian GnRH, because of its discovery in mammals, and is now termed GnRH 1 [48].

Gnrh1, Gnrh2, and Gnrh3 are three paralogous GnRH genes that have arisen during different times of vertebrate evolution [49]. All mammals use Gnrhl to control reproduction and 
therefore this will be the gene referenced in this discussion of the functions of its peptide, GnRH. In mammals, cells containing GnRH are initially found in the nasal placode as early as embryonic day 10.5 in mice. These cells subsequently migrate to the hypothalamus via the vomeronasal-terminal nerve complex [50-52]. The residing location of the migrated neurons is species specific, but in general the result is a scattered continuum of cells from the olfactory bulb to the mediobasal hypothalamus (MBH) [53]. GnRH neurons are most prominent in the preoptic area (POA) and organum vasculosum of the lamina terminalis (OVLT) in sexually mature female pigs [54], sheep [55], and rats [56] while expanding more caudally towards the mediobasal hypothalamus in primates $[57,58]$. They are also present in the diagonal band of Broca, suprachiasmatic nucleus, anterior hypothalamus, $\mathrm{MBH}$, supraoptic nucleus (SON), periventricular zone and paraventricular nucleus (PVN) and ARC in female pigs [54]. Although this migration is not seen in ancestral chordates, the movement is critical in some species as its absence causes infertility or defects in pubertal maturation [59]. The factors influencing GnRH migration have yet to be fully identified but several candidates are thought to be involved. The most studied are adhesion molecules, guidance cues, neurotransmitters, GPCRs, growth factors and transcription factors that modify initial migration and neuronal development along the vomeronasal nerve. Other candidate proteins are involved in GnRH movement caudally toward the forebrain, followed by migration further to the hypothalamus and final detachment from their guides to disperse throughout the hypothalamus [60].

From the hypothalamus, GnRH neurons project their dendrites into the ME and secrete their peptide through axon nerve terminals that appose the portal vasculature. The peptide travels through the portal blood to subsequently act on gonadotropes in the anterior pituitary. Due to the receiving (dendrite) and conducting (axon) nature of these neuronal extensions, they have been 
termed as GnRH “dendrons” [61].

In the event of improper functioning of gonadotropes in the anterior pituitary due to GnRH deficiency, hypogonadotropic hypogonadism $(\mathrm{HH})$ can occur. $\mathrm{HH}$ is characterized by a decrease in gonadotropin secretion which in turns inhibits the growth of the gonads and reproductive function. There are two types of $\mathrm{HH}$, isolated (or idiopathic) hypogonadotropic hypogonadism (IHH) and Kallmann's syndrome [62]. Symptoms in humans with Kallmann's syndrome only differ from IHH by including an impaired sense of smell due to an issue with olfactory bulb development. Since GnRH neurons develop in the nasal placode and migrate to the hypothalamus, any issue with olfactory development could inhibit this migration and ultimately lead to a lack of GnRH secretion [63].

\section{Pattern of GnRH Release}

Research originally performed in ovariectomized rhesus monkeys [64] showed that LH release was episodic. The importance of the pulsatile nature of GnRH secretion to elicit corresponding LH secretion was demonstrated when continuous GnRH was given to rhesus monkeys following hypothalamic lesions. Instead of stimulating a constant and/or elevated release of LH, episodic LH secretion was lost, and mean levels were severely reduced. However, when GnRH was subsequently administered in a pulsatile fashion, episodic LH secretion was rescued. This study emphasized the importance of the pulsatile nature of GnRH release in functioning of the HPG axis [65].

An early debate questioned whether GnRH had a deterministic or permissive role in ovulation, i.e. would GnRH exhibit a significant surge-like increase or remain unaltered during the LH surge. Studies that delivered GnRH at a constant rate of one pulse per 60 to 90 minutes in monkeys with radio-frequency lesions of the ARC still elicited an LH surge and repeated 
menstrual cycles, supporting the contention that GnRH was simply permissive [66]. However, evidence from sheep, rodents and rabbits support a deterministic role for GnRH [67]. Clarke and Cummins [68] pioneered a hypophyseal portal surgery in ewes which allowed for collection of blood directly from the hypophyseal portal vasculature in the sheep and a direct measure of GnRH secretion. Using this approach, they demonstrated a very high correlation between $\mathrm{GnRH}$ pulses in portal blood and LH pulses in jugular blood. In parallel, the push-pull perfusion approach was also being used in rodents, sheep and gilts. This technique involves the placement of two tubes that are perfectly balanced so that one perfuses and bathes an area of tissue with fluid while the other removes it at a similar rate. The perfusate can then be collected for measurement of desired substances such as GnRH. This approach also confirmed a congruency of pulsatile GnRH and LH secretion [69,70]. Several experiments illustrated GnRH's deterministic role in generating the LH surge, and thus ovulation, in sheep. All GnRH pulses were simultaneous with or preceded an LH pulse [69]. Furthermore, the LH surge during ovulation was congruent with or followed an abrupt increase in GnRH that lasted past the duration of LH secretion. Without GnRH secretion, ovulation was blocked [67]. This was important because it showed the direct deterministic influence of GnRH on LH secretion. Similar to what was reported in sheep, GnRH receptor antagonists given to pigs prior to the LH surge inhibited ovulation, thus supporting a deterministic role [71].

\section{GnRH Pulse Generator}

GnRH is released in two "modes" of secretion which are each controlled by different mechanisms [30]. One is termed tonic secretion as it represents a relatively slow and constant pattern of GnRH release. This pattern is characterized by episodes or "pulses" of GnRH into the portal vasculature over a period of days to weeks [72,73]. The consistent pulses of GnRH, every 
1.5 to 2 hours during the follicular phase and every 4 to 8 hours during the luteal phase, induce corresponding tonic secretion of LH and FSH. The pulse frequency of GnRH also varies with stage of maturation, photoperiod conditions, or stage of the estrous or menstrual cycle [72,74]. As mentioned above, the pulsatile nature of $\mathrm{GnRH}$ release is essential for gonadotropin release as desensitization occurs during continuous GnRH stimulation [75].

Tonic secretion of GnRH is driven by relatively nebulous mechanisms in the hypothalamus that have been generally termed the GnRH pulse generator [76]. The activation of this pulse generator leads to GnRH discharge into the hypophyseal portal vessels where the peptide can act via its G-coupled protein receptors in the anterior pituitary gland [48,73]. In the sow, several studies have shown that blocking GnRH secretion from the hypothalamus [77] or disruption of GnRH movement through the portal vasculature by pituitary stalk transection decreases LH release by gonadotropes in the pituitary $[78,79]$.

The neurobiology behind the GnRH pulse generator is still not clear. Two possibilities have been investigated. The first suggests that pulse generation is endogenous to the neurons themselves while the second introduces an extrinsic oscillator that governs GnRH neurons to regulate their pulsatility. Originally it was believed that GnRH neurons had a dense reciprocal network that self-orchestrated their pulsatility. This was demonstrated by an immortalized GnRH cell line (GT1-7) that continues to episodically secrete GnRH in the absence of other cell types. Autocrine regulation in GnRH neurons is seen through agonist activation of the $\mathrm{G}_{\mathrm{q}}$ and $\mathrm{G}_{\mathrm{s}}$ pathways to increase cyclic AMP (cAMP) and $\mathrm{Ca}^{2+}$ signaling. GnRH antagonists and high concentrations of $\mathrm{GnRH}$ initiate the $\mathrm{G}_{\mathrm{i}}$ pathway to decrease these signaling pathways and thus neuronal firing [80].

However, the more recent discovery of a GPR54 mutation that causes hypogonadotropic 
hypogonadism [11,12] introduced kisspeptin into the mechanism and provided evidence for the second possibility underlying the pulse generator. GPR54 is found on GnRH neurons and kisspeptin is a conserved secretagogue of GnRH in many species [48,49]. For example, kisspeptin-10 increases the peak amplitude and duration of GnRH secretion in GT1-7 cells [80]. Furthermore, pulsatility of GnRH is governed by estradiol negative feedback and causes a reduction of hypothalamic GnRH secretion as well as direct inhibitory effects on pituitary $\mathrm{LH}$ secretion [81]. Studies using transgenic mice indicate that ER $\alpha$ is the relevant estrogen receptor in this inhibitory action and that this receptor is expressed in kisspeptin, but not GnRH neurons [8-10]. Estrogen treatment also leads to decreased numbers of kisspeptin-positive neurons in sheep [82]. These findings resulted in the suggested existence of a neuronal network that was extraneous to GnRH neurons, one that involves kisspeptin and orchestrates pulsatile GnRH secretion.

In 2007, Goodman and coworkers [19] described the co-expression of kisspeptin with neurokinin B (NKB), a peptide in which mutations of the ligand or receptor, NK3R, would cause hypogonadotropic hypogonadism [20]. The fascination with coexpression of two peptides that were required for gonadotropin secretion was furthered with the identification of a third peptide, dynorphin, which was also expressed in this population of neurons in the ARC of the hypothalamus. These neurons were termed KNDy neurons using the first letter(s) of kisspeptin, neurokinin B, and dynorphin [83]. While kisspeptin and NKB are stimulatory, dynorphin is inhibitory, and together they work with other intermediary neurons to initiate and terminate the tonic GnRH pulses needed for gonadotropin secretion [84]. The model has been put forward where NKB stimulates kisspeptin release from KNDy neurons and kisspeptin then stimulates GnRH release, with dynorphin then terminating the pulse through local inhibition of kisspeptin 
release from KNDy neurons. This model is in part based on receptor distribution, as KNDy neurons express NK3R and KOR [85], but not GPR54, and GnRH neurons express GPR54, but not NK3R [29]. GnRH neurons do, however, express KOR [85,86], so direct effects of dynorphin on GnRH neurons are possible.

\section{GnRH Surge Generation}

The second type of secretion is termed "surge" secretion and is characterized by a large and sustained increase in GnRH that differs from episodic GnRH pulses [87]. This surge elicits a corresponding increase in LH secretion which acts at the ovary to halt ovarian estrogen synthesis, stimulate completion of the first meiotic division in the oocyte, cause differentiation of follicle cells into luteal cells (luteinization), and culminates in ovulation [88].

Estradiol has a biphasic effect on GnRH secretion and can both stimulate and inhibit its amplitude during release [81,89]. Ovulation is influenced by "positive" feedback from high concentrations of estradiol secreted from growing follicles [90]. The positive feedback initiates action potentials within the GnRH neurons that release large quantities of peptide into the portal vasculature that provides blood to the anterior pituitary. The surge of GnRH induces an LH surge that is greater than 10 times the amount of a standard LH pulse [73]. Although females in all spontaneous ovulating species generate the GnRH and congruent LH surge, there are several species differences regarding the duration, timing and sites within the brain where the surge originates in response to estradiol.

In rodents, the surge is triggered by increased estradiol and progesterone in conjunction with circadian inputs [91] during the late follicular phase that activate neurons in the anteroventral periventricular (AVPV) region of the pre-optic area (POA) [92-94]. Analysis of cFos expression in GnRH neurons shows that the group of $\mathrm{GnRH}$ neurons that are activated lie 
around the organum vasculosum of the lamina terminalis (OVLT) and project to the stalk ME [95]. The SCN receives and mediates light input and is one locale of vasoactive intestinal polypeptide (VIP) synthesis in rats. Lesions in the SCN or disruption of VIP secretion alters the diurnal nature of the LH surge [96,97]. Whether VIP receptors are expressed by GnRH neurons remains unclear and therefore it is unknown whether VIP input is direct or indirect [81]. Kisspeptin neurons located in the AVPV are one set of neurons in this area that expresses ER $\alpha$, increases activity in the presence of elevated estradiol and project to GnRH neurons, thus suggesting a role in surge generation. In addition, vasopressin axonal fibers appose kisspeptin cells in the AVPV and may receive and transmit the circadian signal to influence the GnRH surge [98]. Lastly, since the LH surge is abolished when ERa is selectively deleted from GABA or glutamate neurons, it is also suspected that these classic neurotransmitters play a critical role in surge initiation [99]. The presence of a second preovulatory surge of FSH also differentiates the rat from other species [35].

In sheep, interestingly, the GnRH surge lasts for a much longer period than the LH surge [100]. The mechanism underlying this phenomenon, or any potential purpose that it serves, is not yet clear. In addition, the amount of LH secreted in response to GnRH is much more than the minimum needed to cause ovulation $[81,100]$. The GnRH surge is triggered by high levels of estradiol, but this could possibly occur by actions of estradiol at the hypothalamus, pituitary or both. Initial research placing estradiol microimplants into the medial POA and MBH indicated that the MBH is the primary site of positive estradiol feedback for induction of the GnRH surge [101]. Caraty et al. [102] showed that infusion of kisspeptin synchronized surges of LH to the time of its infusion versus the highly variable surges displayed in controls, suggesting that kisspeptin might be an important component of the GnRH surge in sheep. Subsequent work 
showed that surges only occurred in ewes where elevations in estradiol occurred, which emphasized the importance of estradiol feedback [103]. A role for kisspeptin was confirmed by demonstrating that an infusion of a kisspeptin receptor antagonist reduced the amplitude of the LH surge by approximately 50\% [104]. In recent years, a role for both POA and ARC kisspeptin neurons has developed. With regard to the POA population, expression of kisspeptin mRNA increases during the late follicular phase of the estrous cycle [105]. Additionally, c-Fos expression in POA kisspeptin neurons has been reported to increase during the LH surge by as much as $50-60 \%[106,107]$. Interestingly, this is comparable to the percentage of POA kisspeptin neurons expressing ER- $\alpha$ [9]. However, another study failed to see an increase in the expression of c-Fos in POA kisspeptin neurons [105], even though kisspeptin mRNA expression increased. Although kisspeptin mRNA in the ARC is increased during the late follicular phase [105,108], mRNA expression for the kisspeptin receptor on GnRH neurons did not differ between the luteal and late follicular phase. Similar to POA kisspeptin, reports on activation of ARC kisspeptin neurons during the LH surge are mixed. Studies found increased c-Fos expression in ARC kisspeptin neurons [105,106] and Merkley et al. [109] also reported an increase in glutamatergic input to ARC kisspeptin neurons during the surge that did not arise from other kisspeptin-containing neurons. Nevertheless, another study [107] reported no increase in c-Fos expression in ARC kisspeptin neurons during the surge. Thus, the connection between kisspeptin and the GnRH surge in sheep is not complete.

While GnRH in most species has an active role in generation of the LH surge, whether this is true for the primate and human is less clear. Although a rise in circulating estradiol from growing follicles is required for the pre-ovulatory surge [35], there is some debate on whether a GnRH surge is required or if actions of estradiol at the pituitary level are sufficient $[35,66,110]$. 
Ferin et al. [111] first observed that rhesus monkeys could still produce estrogen-induced LH surges after pituitary stalk transections. As aforementioned, a study in 1980 using rhesus monkeys [66] furthered this idea by showing the necessity for GnRH pulses but not a GnRH surge to produce an LH surge, thus arguing against the requirement for a preceding GnRH surge. Research in women suffering from Kallman's Syndrome, a form of hypogonadotropic hypogonadism, showed that ovulation can be rescued by infusion of intermediate, physiological pulses of GnRH without a GnRH surge [112]. Moreover, activity increases in the pituitary, but not the hypothalamus, during the LH surge, thus supporting the role for estradiol-induced stimulation of the pituitary in women [113]. Other studies in monkeys offer positive evidence for the necessity of the GnRH surge. A significant increase of GnRH was found to be congruent with the LH surge through assessment of push-pull perfusates or cerebrospinal fluid [114]. Additionally, through analysis of hypothalamic multi-unit activity (MUA), a proposed surrogate of GnRH pulsatility, it was determined that tonic GnRH release is arrested during the LH surge [87]. This implies that if secretion of GnRH is still needed for the LH surge, it differs from the tonic pattern of GnRH arising from the pulse generator. Like rodents and sheep, kisspeptin neurons are located within the POA and ARC/Infundibular nucleus of primates and women, but their function has yet to be qualified as critical to surge generation [35]. However, Smith et al. [115] reported that kisspeptin mRNA was higher in both the POA and infundibular nucleus (akin to the ARC in other species) of monkeys during the late follicular phase, although numbers of kisspeptin-positive inputs to GnRH neurons were similar across the menstrual cycle.

In pigs, the temporal relationship between estrus, the preovulatory LH surge and ovulation is crucial for efficient reproduction. Similar to other models, estradiol causes a biphasic effect on gonadotropin secretion and exerts its effects on the hypothalamus [116,117]. 
Although a robust LH increase does not occur in the presence of consistent GnRH stimulation, GnRH is a required for inducing the preovulatory surge in gilts [71,77,78]. Lents et. al [14] has shown the dose-dependent influence of kisspeptin on increasing LH through both ICV and IV infusions, but evidence has been circumstantial regarding the location or mechanisms of kisspeptin's actions within the hypothalamus or pituitary [118], as both are necessary to generate the LH surge in the pig [77]. There is still much research needed to properly detail the mechanisms of the porcine LH surge generator.

\section{Endocrinology of Puberty Onset}

\section{Estrogen Feedback and the LH Surge}

Prior to puberty, low concentrations of estrogen provide negative feedback at the level of the hypothalamus to inhibit pulsatile GnRH/LH secretion in pigs [119]. Surge-like, estradiolinduced increases in LH do not occur until approximately 160 days of age in the gilt with a weak response beginning around 60 days [120,121]. Post-pubertal gilts experience steroid negative feedback during the luteal and follicular phases of their reproductive cycles with a release from that feedback around the time of ovulation. In the late follicular phase, a decrease in pulsatile and mean LH, caused by estrogen's inhibition of GnRH secretion, is required for 2-3 days before the preovulatory surge can occur $[6,78,79]$. As the Graafian follicles continue to grow and secrete estradiol, a threshold level is reached, and this feedback converts from a negative to a positive one. The stimulatory effects of estradiol are exerted at the pituitary by stimulating GnRH receptor production and increasing LH secretion in response GnRH [122] while also influencing GnRH neurons in the hypothalamus [67,119]. The removal of estrogen negative feedback increases secretion of GnRH and results in a subsequent elevation in $\mathrm{LH}$ (average $5.2-8.7 \mathrm{ng} / \mathrm{ml}$ ) the day before or on the day of ovulation [123]. The surge causes the final maturation of selected 
follicles and stimulates the closure of gap junctions to release the oocyte from the follicular cells. Simultaneously, this closure removes the influence of cellular inhibitors that cause nuclear arrest, thus leading to the resumption of meiosis as an event that occurs before ovulation in pigs, sheep, mice and hamsters [73].

\section{Other Important Factors}

During maturation, sexual function is one of the later things to develop during the pubertal period and occurs during a specific stage of growth in a species [124]. Gonadotropins are initially high after birth but are then inhibited during the infantile period by estradiol negative feedback in several species, including swine. Puberty onset in the gilt is brought about by the resumption of gonadotropin secretion which leads to first estrus and the onset of reproductive capability [125]. Gilts that reach puberty earlier have increased retention in the breeding herd, farrow more litters per sow and produce more pigs per litter; and remain fertile longer throughout their breeding lifetime $[43,126]$. The specificity of puberty's timing is influenced by several factors, including an animal's weight, age, growth, and seasonal receptivity. Not surprisingly, this has led to various theories on a specific mechanism that induces puberty onset.

Ramirez and McCann [127] proposed a gonadostat theory in which they believed the prepubertal inhibition of $\mathrm{LH}$ secretion was due to heightened sensitivity to estradiol negative feedback within the hypothalamus. During infancy, the hypothalamus is highly sensitive to the low titers of estradiol secreted from the gonads and, thus, gonadotrope function would remain inhibited. As the animal matured, the hypothalamus would become less sensitive to estradiol negative feedback and gonadotropin secretion would rise [128]. Initial studies analyzing LH secretion before puberty indicated that the gilt conformed to this gonadostat theory [40]. However, this theory fell into disfavor when the castration of young macaques [64] and ewe- 
lambs [129] did not immediately release the hypothalamus from inhibition and increase gonadotropin levels. This indicated that pre-pubertal inhibition of LH secretion is not primarily controlled by estradiol negative feedback, but instead by another potential factor or pubertal signal. In this case, a pubertal signal is defined as a substance that is "quantitatively different for the sexually immature and sexually mature individual" and when administered must significantly change GnRH whether advancing or delaying it [130]. Subsequently, the role of estradiol negative feedback as a requirement for the prepubertal inhibition of LH secretion has been confirmed in domestic livestock species but is not responsible for the juvenile hiatus in LH secretion noted for primates. Some other important factors that influence the onset of puberty in the gilt are body fat or body composition [131,132], growth rate [133] and leptin [134].

\section{Back Fat/Body Composition and Growth Rate}

The nutritional state of an individual plays an important role in that individual's ability to reproduce. Undernutrition delays puberty and disrupts estrous or menstrual cycles by negatively influencing GnRH and LH secretion [132,135,136]. This is not surprising as the process of reproduction requires more energy than needed for other life processes and a lack of adequate body fat would risk the lives of the mother as well as her offspring [135]. Based on data from studies using rats [132], it was suggested that vaginal opening, a sign of pubertal maturation in rodents, was more correlated with body weight than it was with age. In addition, chronic underfeeding in rats leads to reduced body growth and delayed sexual maturation [137].

Frisch [138] correlated the relationship between fat percentage and the potency of circulating estrogen as well as levels of circulating sex-binding globulin in women. She also determined even moderate weight loss can lead to amenorrhea due to decreased control of body temperature, energy storage and metabolism [135,139]. Overall, studies in women emphasized 
the connection between an ideal weight to height ratio and menarche, indicating that menstrual disorders can occur in both excessively lean and obese women [135,140].

In swine, the ratios between back fat, weight and age are controversially connected to age at first estrus and other parameters that measure reproductive success $[125,141,142]$. Although they may be correlated, back fat, age and weight at first breeding have not been shown to significantly affect indices of sow productivity such as litter size [141]. Furthermore, there is research showing a low correlation between back fatness and age at first estrus [143]. However, in other studies, back fat thickness positively correlated with age of puberty, an increase in total piglets born, and a decrease in the time between weaning and return to estrus [144-146]. Gilts fed a diet with increased fat content exhibited a significantly lower age at puberty, enhanced gonadal development, longer uterine horns and higher Kiss-1, GPR54, FSH and LH mRNA expression in the hypothalamus and pituitary [147].

Body composition can be correlated with feed intake and growth rate. Since feed intake and backfat have an influence on reproductive development [125,148], it is not surprising that growth rate does as well. Gilts with higher growth rates from birth to a peripubertal age achieve puberty faster than those with slower growth rates [133,149]. Replacement gilts with higher growth rates also show earlier signs of estrus [150]. However, results from Rozeboom [125] and other authors are in direct conflict with these findings, with the authors stating that growth rate has no correlation to age at puberty $[151,152]$. Still, sows with faster growth rates have a shorter weaning to estrus interval with an average of 4-7 days [6,146,153]. Previous work using quantitative genetics (REML) show significant heritability between weaning to estrus interval and age at puberty $\left(h^{2}=0.45\right)$, thus, there may be a strong link between faster growth rate and age at puberty [154]. To complicate the connection further, the effect of growth rate on age at 
puberty is correlated with the age at first boar exposure which can vary greatly between herds [42]. Current strategies for selecting maternal line gilts includes growth rate as well as body composition, age at first mating, sexual development and reproductive history [44]. Many factors impact sow longevity and reproductive success and therefore all should be considered when determining their influence on puberty.

\section{Leptin}

While Dr. Rose Frisch originally described the proposed positive relationship between body adipose and puberty onset [135], the mechanism of how body fat would communicate with the brain, and more specifically the hypothalamus, was unclear. Cloned and discovered in 1994 [155], leptin is a $16 \mathrm{kDA}$ protein that is translated by the LEP (previously OB) gene and binds to several leptin receptor (Ob-R) isoforms, Ob-Ra, Ob-Rb, Ob-Rc, Ob-Rd and $\mathrm{Ob}-\mathrm{Re}$. Ob-Rb, also written as Ob- $\mathrm{R}_{\mathrm{L}}$ or LepRb, is the long form of the receptor and acts via the JAK-STAT pathway in the hypothalamus as well as MAP Kinase or PI-3 Kinase pathways in different parts of the body [156-159].

Through long form receptor activation, leptin reduces food intake and regulates energy balance by stimulating neurons containing anorexigenic peptides such as pro-opiomelanocortin (POMC) and cocaine- and amphetamine- regulated transcript (CART) while inhibiting orexigenic neurons that stimulate feeding, such as neuropeptide Y (NPY) and agouti-related peptide (AgRP). The short isoforms of the receptor are believed to be more involved in transporting leptin across the blood-brain barrier [136]. Although the gene for leptin is largely expressed in white adipose tissue [155] and circulates in concentrations that reflect fat reserves in the body, it can also be found in the placenta, ovary, pituitary gland and mammary gland [158]. It was believed to be the bridge that connected body fat or body composition to reproductive 
function [160] by translating information regarding energy stores (i.e. adipose tissue) to the hypothalamus [161]. That leptin connects adiposity/nutritional state with reproduction can most clearly be seen by recognizing that mice lacking leptin, the ob/ob mouse, are infertile. In addition, leptin injections restore gonadotropin secretion and thus reproduction in these mice [162].

Long-form leptin receptor mRNA was localized to the ARC of the hypothalamus and anterior pituitary in the pig [163], ewe [164], rat [165] and mouse [166]. More specifically, this signaling form of the leptin receptor has been found to be expressed at varying levels in KNDy neurons that are known to have an important role in controlling GnRH release [29]. It was reported that there existed less than $10 \%$ colocalization between Kiss1 neurons and leptin receptor in intact mice [167] and no colocalization was found in rats [168]. In addition, conditional knockout of the leptin receptor from Kiss1 neurons (Kiss1-Cre/LepR-floxed) did not alter sexual maturation or fertility in male or female mice [169]. On the other hand, Smith et al. [170] used in situ hybridization to show that $40 \%$ of Kiss 1 neurons in the ARC contain leptin receptor mRNA while another study showed $80 \%$ colocalization in guinea pigs using single cell PCR and electrophysiological recordings [171]. Even further, neuromorphological studies using pseudorabies virus have shown the presence of a multisynaptic connection between adipose tissue and nuclei throughout the hypothalamus, including the ARC [172]. These studies provide evidence that peripheral leptin may alter GnRH release, gonadotropin secretion and estrous or menstrual cycle expression, but these effects could be dependent upon species [134,173].

Currently, the role of leptin in puberty is contentious. There has been conflicting evidence towards whether leptin is simply a critical, but permissive, signal or if it is an active regulator of puberty onset. In mice, daily injections of leptin accelerated vaginal opening, first 
estrus and onset of cyclicity without significantly altering body weight [161]. However, the acceleration of puberty onset was relatively small and in a subsequent study [174], rats injected intraperitoneally with leptin failed to show a significant acceleration of vaginal opening. In that study, leptin reversed the delaying effects of feed-restriction on puberty but had no significant affect in well-nourished animals. Similarly, leptin increases LH secretion in food-restricted sheep [179], but does not alter concentrations in well-nourished sheep [180]. In primates, one study reported no association between changes in circulating leptin levels and pubertal changes in LH secretion [175], but other studies [176,177] demonstrated a positive connection between leptin and increases in nocturnal and daytime LH secretion, estradiol and menarche. Another foodrestriction study showed that leptin infused into the lateral ventricle of female rats increased the weights of ovaries and uteri [178]. Therefore, one thing that seems universally clear is that leptin can restore LH secretion or reproductive function in situations of undernutrition. In gilts, leptin increases at the time of puberty onset, but has been reported to stimulate, inhibit or have no effect on LH secretion $[134,181]$.

\section{The Estrous Cycle of the Pig}

Phases

Gilts become sexually mature from 8 to 12 months of age, depending on factors including age at first boar contact and body condition. They average a 21-day estrous cycle and are polyestrous $[6,79]$. The estrous cycle is made up of four stages - estrus, metestrus, diestrus and proestrus - with simultaneous ovarian phases - follicular and luteal. Proestrus and estrus occur during the follicular phase, which is shorter than the luteal phase, and lasts for roughly 20\% (4-7 days) of the entire cycle. Metestrus and diestrus occur during the luteal phase, which lasts 13-15 days $[6,73]$. 
Estrous behavior and sexual receptivity occur during the estrus period, which is heavily influenced by olfactory and tactile stimulation. The physical signal of estrus is called the lordosis response and is characterized by a standing action in the presence of a boar wherein the gilt or sow arches her back, erects her ears and remains immobile [182]. Occurring during the follicular phase, estrus lasts an average of 30-60 hours in sows [73,123].

At approximately two-thirds the way through the estrous period, estrogen concentrations begin to rise to threshold levels, exerting positive feedback onto the hypothalamus. As stated above, this results in the GnRH, and thus $\mathrm{LH}$, surge. $\mathrm{LH}$ acts on the theca interna cells to destroy follicular tissue around the dominant follicles, causing ovulation of the cumulus oocyte complex (COC). Ovulation occurs at an average of $30 \pm 3$ hours after the onset of the LH surge [183] with pigs generally ovulating 15-30 oocytes per estrus period. Observation of the standing estrus response and calculation of the relationship between the estrus period and ovulation are both used as tools to optimize timing of breeding or artificial insemination [6].

The next stage, metestrus, marks the transition from the follicular phase to the luteal phase. Initially, both estrogen and progesterone levels are minimal. The low levels of estrogen result in the removal of negative feedback on FSH secretion. FSH is highest post-ovulation and stimulates waves of small and medium follicle development during the luteal phase [6]. Congruently, LH pulses continue to occur every 3-6 hours [184] and act on theca cells as they transition from follicular to luteal cells in a process called luteinization.

Diestrus is the longest of the four stages and lasts approximately 15 days. It is marked by the completion of luteinization 8-9 days after ovulation, resulting in dramatically increased progesterone levels soon after the corpus luteum is fully functional [6]. Factors like vascular endothelial growth factor (VEGF) and insulin-like growth factor (IGF-1) are major influences in 
the formation of the corpora lutea during this process. The infusion of exogenous IGF-1 into the ovarian vasculature increases the secretion of progesterone from the transforming luteal cells [6]. Progesterone negative feedback is exerted on the hypothalamus which results in low concentrations of gonadotropin secretion in addition to low estrogen concentrations because of inhibited follicle development [185]. Unlike what occurs in cows, it is debated whether full follicular waves continue to persist through this period of inhibition in pigs. FSH waves are observed, but follicle numbers remain limited [6]. During this period of progesterone negative feedback, LH pulses continue to occur 6 times a day, i.e. approximately one every 4 hours, similar to the metestrus period.

In the absence of an established pregnancy, uterine secretion of prostaglandins occurs. These eicosanoids enter the circulation and causing luteolysis approximately 15 days after ovulation. As the luteal phase ends, the 4 to 6 -day follicular phase begins with the proestrus stage. Loss of the corpora lutea causes a decrease in circulating progesterone levels, thus leading to a loss of progesterone negative feedback at the level of the hypothalamus. Without this inhibition, the hypothalamus releases $\mathrm{GnRH}$ at increased frequencies, resulting in a pattern of LH secretion characterized by higher frequency, but lower amplitude, pulses and FSH release [6].

FSH is a glycoprotein hormone secreted from the anterior pituitary that acts directly upon the ovary to induce development of the small antral follicle pool that arose during the luteal phase [7]. Even small amounts of FSH are adequate to stimulate the recruitment and growth of a group of antral follicles until the dominant follicles are selected. In pigs and other animals that are polytocous, a cohort of follicles is chosen as dominant whereas only one follicle is chosen in other species that are monotocous [73]. At this point, LH pulses have increased to one every 1-2 
hours to aid in the selection process of the recruited follicles [184,186]. These selected follicles continue to secrete estradiol as well as inhibin during growth. Due to specificity of selection, inhibitory actions of inhibin on FSH secretion and the disproportionate blood flow to the dominant follicles, the rest of the recruited pool will undergo atresia. As estrogen levels begin to rise to threshold levels, the cycle repeats itself and leads to the GnRH and LH surges that started the aforementioned estrous cycle.

\section{Steroid Action and Feedback}

$\mathrm{LH}, \mathrm{FSH}$, progesterone, and estrogen have critical roles during the reproductive cycle. While LH and FSH are secreted from gonadotropin cells in the anterior pituitary, progesterone and estrogen are released from the ovarian granulosa and thecal cells and provide feedback to the brain to control the release of GnRH and, thus, LH and FSH.

LH and FSH work harmoniously to mature gametes, develop gonads and promote ovulation in females [123]. The primary role of FSH is to stimulate antral follicle growth during the follicular period by acting via G-protein coupled receptors on the granulosa cells in the ovary. Also necessary for follicle development, LH is required to further follicle growth and achieve dominant follicle selection. Follicles that do not have the proper number of LH receptors during this time of LH dependence will undergo atresia [73]. Furthermore, LH also acts on the theca cells to convert cholesterol to progesterone so that, simultaneously, the aromatase enzyme, which is stimulated by actions of FSH on granulosa cell receptors, will convert testosterone to estrogen [187]. After ovulation occurs, LH continues its actions on the theca and granulosa cells to promote luteinization. Therefore, both of these hormones work together to grow the follicles, synthesize estradiol and progesterone and promote the events leading to ovulation [73].

Estrogen and progesterone are synthesized and secreted in response to LH and FSH 
actions on the gonads. As stated, estrogen is synthesized by the granulosa cells when both gonadotropins are present as synthesis requires the action of both FSH and LH on granulosa and theca cells, respectively. Estrogen acts on several parts of the female reproductive tract to increase overall blood flow in preparation for copulation during estrus. High concentrations will increase mucosal secretion in the caudal/cranial vagina and cervix to lubricate the vagina, flush out foreign material and aid in sperm travel into the uterus [73]. It also acts to thin the cervical mucus and increase uterine contractility to aid in sperm passage to the oviduct.

Additionally, estradiol has a biphasic feedback action on the pituitary and hypothalamus [119]. Low levels during the early follicular phase exert a negative feedback that decreases LH amplitude and mean LH secretions as well as GnRH concentrations in the MBH and hypophyseal portal vasculature $[30,116,188,189]$. The first clue that estrogen had a positive effect to induce ovulation was seen in rats in 1934 when administration stimulated the formation of corpus lutea [4]. Thus, as in many other mammalian species, the influence of estrogen moves from being inhibitory at low levels of secretion during the prepubertal period to be periodically positive as the gilt enters puberty and throughout repeated estrus cycles [3,190]. As follicles grow and increase secretion of estrogen, levels of the steroid surpass a threshold wherein they trigger a sudden outpouring of large concentrations of GnRH that lead to the LH surge [191]. The surge created from elevated concentrations of estradiol is specific to sows and is not found in their male counterparts, as is the case for many other species as well [120,192]. Estrogen binds at least two classical nuclear receptors (ER $\alpha$ or $E R \beta)$ as well as membrane-bound receptors (for example, GPR30). While the physiological role of membrane-bound ER is unclear, ER $\beta K O$ mice are still fertile while ER $\alpha \mathrm{KO}$ are not, suggesting that ER $\alpha$ is the likely receptor for mediating both negative and positive feedback [193]. 
Circulating concentrations of progesterone are largely derived from the corpus luteum, but small amounts are also released by the theca cells before ovulation. Low levels of progesterone cause the synthesis and activation of collagenase enzymes that aid in breaking down the follicular tissue for rupture. In contrast, high levels of progesterone strongly inhibit all estrous behavior and potently reduce GnRH and gonadotropin secretion [73,194]. Progesterone can work independently or in conjunction with estrogen and primarily inhibits the frequency, but not amplitude, of LH pulses [188,195]. At certain doses, progesterone inhibits the onset of estrus and ovulation in sheep, cattle and gilts [196]. Treatment of goats with combined estrogen and progesterone implants lowers the frequency of MUA volleys near KNDy neurons in the MBH [17], while subcutaneous injections and bilateral cerebral implants of crystalline progesterone blocked ovulation and the LH surge as well as decreased sexual receptivity in sheep and pigs [182,194,197,198]. Hypothalamo-pituitary disconnection limits the actions of progesterone on LH secretion [199], showing that progesterone acts on the hypothalamus and not directly on the pituitary as estrogen can. There is evidence that inhibition of the GnRH surge by progesterone occurs within the MBH and VMH while its effects in the POA inhibit estrus activity [198]. Regardless of its inhibitory effects, progesterone signaling in rodents is critical for proper ovulation and fertility during the LH surge [200].

Although it is evident that progesterone and estrogen act within the hypothalamus to regulate GnRH release, the neural mechanisms whereby this occurs is not completely clear. It is well known that GnRH neurons do not express ER $\alpha$ or the receptor for progesterone (PR), so a direct effect of either steroid is unlikely. There is sufficient evidence to suggest that KNDy neurons play an intermediary role in mediating feedback from both steroids [29]. Information discussing how this occurs is considered in the next section. 


\section{KNDy neurons}

\section{Introduction}

Colocalization of kisspeptin, NKB and dynorphin within neurons of the ARC of the hypothalamus have been noted for rats, mice, sheep and goats [29], although colocalization in humans is less clear [201]. Kisspeptin and NKB, and their respective receptors, have been shown to be critical for puberty onset in humans $[11,20]$ and both elicit GnRH and/or LH secretion in various species, including primates [23], rodents [31,202], goats [17], heifers [34] and sheep [18]. While kisspeptin and NKB are found to be primarily stimulatory to GnRH secretion, dynorphin has been proposed to be inhibitory [30-32]. Currently, the hypothesized mechanism for pulse generation implicates NKB as a local stimulator of KNDy neurons which project to GnRH neurons. This results in the release of kisspeptin at GnRH soma or at GnRH-containing terminals in the ME, therefore leading to a pulse of $\mathrm{GnRH}$ that is secreted into the portal vasculature. To terminate the pulse, dynorphin acts on KNDy neurons to inhibit kisspeptin release and stop GnRH secretion. This oscillation of KNDy peptide release causes the pulsatile release of GnRH that is necessary for LH secretion and reproductive development [30].

\section{Kisspeptin}

\section{Characterization}

Kiss- 1 was initially discovered through its role as a cancer suppressor gene (and was even originally called metastin) in 1996 [203] because kisspeptin mRNA was overexpressed in cells with low metastatic activity. Kisspeptins are the peptide products of the Kiss-1 gene and are cleaved during processing into various isoforms, including kisspeptin-10, kisspeptin-14, and kisspeptin-13. The main product, kisspeptin-54, is a 54-amino acid peptide mostly found in the placenta [1,204]. Their common receptor, GPR54, was cloned in both rats [205] and humans 
[206] and is known to act as a $\mathrm{G}_{\mathrm{q}}$ GPCR through the MAP kinase pathway. There is a lack of gonadotropin response after kisspeptin administration in GPR54-null mice, indicating that the effects of kisspeptin are mediated through this single receptor [24]. Previous research defined the role of the Kiss-1/GPR54 system in cancer biology, placenta formation [207] and the potential control of oxytocin release [208]. It was not until 2003 that a mutation in GPR54 was linked to idiopathic hypogonadotropic hypogonadism [11] and kisspeptin was acknowledged to play a fundamental role in controlling reproductive function. Furthermore, this mutation causes a decrease in secretion of $\mathrm{GnRH}$ without affecting pituitary responsiveness to it, indicating that the Kiss-1/GPR54 mechanism and the role of kisspeptins did not involve actions at the pituitary $[12,209]$.

\section{$\underline{\text { Distribution }}$}

Due to its various roles in many physiological systems, kisspeptin is found in varying parts of the body as well as parts of the brain. There are large populations of kisspeptin found in the ARC and POA/AVPV that are critical for reproduction. As aforementioned, GPR54 expression is primarily found in the placenta, pancreas, spinal cord, pituitary and colocalizes with GnRH neurons in the hypothalamus [210]. The Kiss-1 gene is also found in the human placenta and brain with lesser amounts in the testis and small intestines [211].

During sexual development, the expression of Kiss-1 and GPR54 mRNA increases at the time of puberty in rats [211] and primates [212]. Simultaneously, kisspeptin neurons in the AVPV increase in cell numbers and numbers of close contacts onto GnRH neurons in the POA during the peripubertal period [213]. In the ME, there are abundant contacts between GnRH and kisspeptin neurons [214]. These changes, along with the increasing sensitivity of GnRH neurons to kisspeptin, from $27 \%$ of $\mathrm{GnRH}$ neurons responding to kisspeptin in the prepubertal period to over $90 \%$ as puberty approaches [215], shows the crucial role of kisspeptin in the increased 
activity of the HPGx during puberty onset.

Within the ARC, GPR54 is not found on KNDy neurons [216], therefore making it unlikely that kisspeptin acts to influence its own secretion. Direct injections of kisspeptin antagonist into the arcuate, however, do decrease pulsatile LH secretion [217], indicating some action for kisspeptin in that location. Other cell types (i.e. NPY, AgRP, POMC) exist within the $\mathrm{ARC}$ and at least AgRP and POMC neurons have been shown to respond to optogenetic stimulation of kisspeptin neurons [218]. All three of these peptides have been shown to influence LH secretion [219-222] and such findings raise the possibility that kisspeptin could act directly on the GnRH neuron to influence secretion or indirectly through other peptidergic inputs.

\section{$\underline{\text { Function }}$}

Kisspeptin is a potent stimulator of GnRH release. That it acts directly on GnRH neurons is suggested by the high expression of GPR54 in GnRH neurons [223] and the increased c-Fos expression in GnRH neurons when kisspeptin is injected in rats [224]. Furthermore, kisspeptin induces GnRH release in hypothalamic explants from rats [225] and in sheep in vivo [24] in a fashion that mimics the frequency of the injection with high fidelity [226].

After determining its relationship to GnRH neurons, additional studies showed that kisspeptin-10 and metastin (kisspeptin-54) caused dose-dependent increases in LH and FSH release when given IP, IV or subcutaneously in multiple species [13,15,24,212,227,228]. Doses as low as $100 \mathrm{fmol}, 0.1 \mu \mathrm{g}$ and $2 \mu \mathrm{g}$ were able to stimulate LH release in mice [13], rats [229] and monkeys [16], respectively, while FSH release was 100-fold less sensitive to intravenous kisspeptin-10 administration [230]. Additionally, kisspeptin administration advances vaginal opening and LH levels in immature female rats [211] as well as pulsatile GnRH release in juvenile primates [16]. These actions of kisspeptin are dependent upon GnRH release as 
pharmacologically blocking the GnRH receptor blocks the effect of kisspeptin on LH and FSH release $[13,212,228]$.

\section{Neurokinin B}

\section{$\underline{\text { Characterization }}$}

Neurokinin B (NKB) is a member of the tachykinin peptide family and has been investigated in the context of puberty since the early 1990's [231-233]. The tachykinin family includes substance P (SP), neurokinin A (NKA), neuropeptide K (NPK) and neuropeptide gamma (NP $\gamma)$. NKB is encoded by the TAC3 or Tac2 gene (nomenclature dependent upon species) and its primary receptor, NK3R, is encoded by TACR3 or Tacr3 [234], albeit there is evidence for NKB binding to other tachykinin receptors such as NK1R and NK2R [235]. Like kisspeptin, mutations in genes coding for NKB or NK3R cause hypogonadotropic hypogonadism in humans $[20,236]$. However, species differences exist as to the critical nature of NKB for reproduction as $\mathrm{Tacr}^{-/-}$mice remain fertile [237].

\section{$\underline{\text { Distribution }}$}

Although, NK3R mRNA is located throughout the POA and hypothalamus, with expression noted in the PVN, SON, ventromedial hypothalamus and ARC [22,231,233,238,239], NKB is concentrated only within the ARC [231,233,238,240,241]. NKB-containing fibers from ARC KNDy neurons innervate GnRH axon terminals in the stalk-ME [81,242], but as mentioned earlier, GnRH is not directly modulated by NKB. In most species, NK3R, unlike GPR54, does not colocalize with GnRH neurons although some evidence has been found in the rat medial POA, OVLT and ME [241]. Additionally, studies showed evidence for close contacts, albeit minimal, between NK3R and GnRH cell bodies in the POA and ME of rats and sheep [241,243]. In the ARC, almost all (97\%) NKB neurons contain ER $\alpha$ [238] and NKB mRNA and 
protein expression is significantly reduced by estrogen negative feedback [26,31,233]. Since NKB and NK3R are co-expressed in KNDy neurons $[31,33,244]$, there is a likelihood that reciprocal connections exist for NKB-mediated, local actions on KNDy neurons within the ARC.

\section{Function}

Similar to kisspeptin, NKB is a potent stimulator of LH secretion in mice [31,202], goats [17], sheep [25,32] and monkeys $[23,28]$. However, studies in rats have reported both inhibitory and stimulatory effects of NKB, perhaps due to varying steroidal milieus between studies $[22,245]$. The actions of NKB influence LH secretion through NK3R-containing cell populations in the ARC, POA and RCh of the hypothalamus [244,246]. When the NK3R agonist, senktide, is injected directly into the ARC of rats, there is a dose-dependent decrease in LH secretion as well as a reduction in Gnrhl and GPR54 mRNA. Both of these reductions may be mediated through autocrine dynorphin and KOR inhibitory signaling that occurs through KNDy neurons [242]. On the other hand, senktide induces a surge-like LH secretion when administered locally to the RCh or POA of ewes [246]. The partial blockade of an estrogen-induced surge by a NK3R antagonist delivered only to the RCh emphasizes the importance of this area for full expression of the GnRH surge [246]. Further research shows that placement of senktide within the RCh led to activation of ARC kisspeptin neurons, providing one possible pathway whereby NK3R activation in the RCh may contribute to GnRH release [247]. Micro-implants of senktide only moderately, but significantly, increased LH secretion when administered to the ARC, perhaps indicating a role for NK3R activation in that area for tonic, but not surge, secretion [246]. Expression of NK3R on KNDy neurons clearly suggests that NKB can act to stimulate KNDy neurons and thus kisspeptin release to alter GnRH secretion [244]. That this is true is shown by the ability of a kisspeptin receptor antagonist to block the stimulatory effects of senktide on LH release $[27,28]$. Furthermore, the administration of senktide dramatically activates kisspeptin 
neurons in the arcuate [22].

Dynorphin

\section{Characterization}

Dynorphin is an endogenous opioid peptide (EOP) that has a high affinity for the $\kappa-$ opioid receptor (KOR). Dynorphin is derived from the prodynorphin gene that consists of 4 exons and three introns [248-250] with exons 3 and 4 containing the coding region of the peptide. The processing of dynorphin from the larger inactive precursor (prodynorphin) requires the actions of prohormone convertases 1 and 2 as well as carboxypeptidase E [251] and leads to several forms of dynorphin. While processing is traditionally considered to occur mainly in the trans-golgi network, the presence of both prodynorphin and dynorphin in the same axon and vesicles [252] raises the possibility of processing by other factors or stimuli at the level of the synapse.

\section{$\underline{\text { Distribution }}$}

Dynorphin is found in many areas of the brain. Within the hypothalamus, dynorphin can be found in several nuclei. Certain similarities exist in humans and non-human primates, with dynorphin-positive cells found in the medial preoptic area, SON, PVN, ARC/infundibular nucleus, VMN, dorsomedial hypothalamus, lateral hypothalamus, and mammillary nucleus $[253,254]$.

In tissue collected from female rats on the morning of proestrus, Burke et al. [33] found dynorphin-positive cell bodies in small numbers in the periventricular hypothalamus and anterior hypothalamus. Numerous dynorphin-positive cells were found in the SON and PVN and dynorphin perikarya were found in the ventrolateral and dorsomedial subdivision of the VMN. A moderate population was found within the $\mathrm{ARC}$, with larger numbers in the posterior portion 
of the ARC. Approximately 60 to $65 \%$ of these cells within the ARC also expressed NKB and virtually all expressed ER- $\alpha$. Fibers that were immunopositive for both NKB and dynorphin were found in small numbers within the medial preoptic nucleus, PVN AVPV, and OVLT. Consistent with the extensive reciprocity exhibited by KNDy neurons, there was a dense network of fibers within the ARC and fibers were also located within both the internal and external zone of the ME. Scattered dynorphin cells were also found within the POA [33]. There is conflicting evidence for a direct influence by dynorphin on GnRH neurons in this area. Weems [85] reported that a high percentage $(97.4 \%)$ of GnRH neurons in the rat POA contained KOR protein, whereas an earlier study did not find colocalization [255].

In sheep, Marson et al. [256] reported that dynorphin was found primarily in the SCN and SON and that no dynorphin neurons were found in the PVN while Sliwowska et al. [257] and Foradori [258] described dynorphin-positive cells in the ARC. Iqbal et al. [259] localized mRNA within the SON, PVN, and VMH, but reported that they found few cells elsewhere, including the lateral hypothalamus. A recent study in prepubertal female sheep reported dynorphin-positive cells in the POA and PVN, but failed to find any within the ARC, even though cells were clearly evident in that region for tissue run concurrently from luteal phase ewes [86]. KNDy neurons highly coexpress KOR and there is a high degree of coexpression between KOR and GnRH cells as well [85]. Furthermore, $90 \%$ of GnRH neurons in the MBH are closely apposed by dynorphin fiber varicosities while fibers co-expressing dynorphin and NKB in the ME also contact GnRH neurons [19]. To my knowledge, the distribution of dynorphin in the porcine brain has not been described.

\section{Function}

Dynorphin has been implicated in several physiological functions, including food intake [260], water/fluid balance [261], stress [262], and lactation [263]. Dynorphin also has an 
important role in reproduction. Although mice exhibiting global deletion of either dynorphin or KOR exhibit normal fertility [264,265], it is possible that compensation occurs during development that allows for normal fertility in these mice. In contrast, there is a large body of evidence suggesting that dynorphin can significantly impact reproduction. For instance, dynorphin is thought to mediate the inhibitory influence of progesterone on LH secretion in sheep. Dynorphin neurons coexpress receptors for progesterone [266] and, as mentioned above, are observed to exist within regions of the hypothalamus and POA known to be important for regulating reproduction. Goodman et al. [267] showed that blockade of the KOR within the MBH or POA during the luteal phase increased circulating LH levels in sheep. Additionally, administration of progesterone to ovariectomized ewes increases dynorphin levels in the cerebrospinal fluid compared to ovariectomized controls [258]. In that same study, it was reported that ovariectomy decreased preprodynorphin mRNA-containing cell numbers in the POA, anterior hypothalamic area, and ARC. These effects are reversible as treatment with progesterone restored cell numbers in the POA and anterior hypothalamic area but had no effect within the ARC. Similarly, implantation of the progesterone antagonist, RU486, within the ARC disrupted inhibition of LH secretion brought about by peripheral progesterone administration [268] and administration of the KOR antagonist (nor-BNI) within that area increases LH. In goats, infusion of dynorphin into the lateral ventricle decreased MUA in association with reduced LH secretion, whereas infusion of nor-BNI increased both MUA and LH secretion [17]. Thus, the preponderance of evidence in adult animals of various species would suggest that dynorphin serves an inhibitory function in regulating $\mathrm{GnRH}$, and thus $\mathrm{LH}$, secretion.

While the influence of progesterone has been well studied, the effects of estradiol on dynorphin expression are not as clear. Dynorphin protein expression, as well as KOR expression, 
was surprisingly inhibited by estrogen in mice [31]. In prepubertal sheep, however, dynorphin cell numbers were not affected by estradiol treatment in the PVN [86].

In addition to a potential role for regulation of GnRH secretion in adult animals, a very limited number of recent studies points to a potential role for dynorphin in regulating puberty onset. Nakahara et al. [270] showed that intraperitoneal infusion of nor-BNI accelerated puberty onset in female rats. In prepubertal sheep that had been ovariectomized and implanted with estradiol, infusion of nor-BNI into the lateral ventricle increased LH secretion [86]. Interestingly, this effect was lost in the same cohort of sheep at a postpubertal age, suggesting that dynorphin may play a role specific to the prepubertal restraint of LH secretion. The specific group or population of dynorphin neurons that are involved in this restraint is still unclear. Lopez et al. [86] failed to find dynorphin protein expression within the ARC of prepubertal $\mathrm{OVX}+\mathrm{E}$ sheep and other populations (POA/PVN) were unchanged by treatment with estradiol. In a subsequent and as yet unpublished study, implantation of nor-BNI within the POA or MBH was without effect on LH secretion in prepubertal OVX+E ewes (Michelle Bedenbaugh, personal communication). Thus, much remains to be determined with regard to the mechanism(s) whereby dynorphin impacts GnRH, and thus LH, secretion. As mentioned previously, dynorphin is coexpressed in neurons of the ARC which express kisspeptin and NKB and may play a role in pulse generation, specifically pulse termination. In addition, KORs are also expressed in GnRH neurons $[85,86]$, raising the possibility of direct regulation of GnRH secretion. 


\section{CHAPTER III: CHARACTERIZATION OF KNDY NEURONAL ACTIVITY IN GILTS: DISTRIBUTION AND EFFECT OF A PROGESTIN}

\section{Introduction}

Puberty is an event that is influenced by hormonal, physiological and physical factors that ultimately lead to an ability to reproduce. For puberty to occur, the totality of these inputs must be transduced into information that causes an increase in the pulsatile release of gonadotropin releasing hormone $(\mathrm{GnRH})$. Potently inhibitory to GnRH release during the prepubertal period, estradiol negative feedback lessens [3] as the individual matures, allowing for an increase in pulsatile GnRH, and thus $\mathrm{LH}$, release. When ovarian estradiol secretion induced by LH reaches a threshold level, it triggers a surge in GnRH and LH that stimulates the first ovulation [5,6]. GnRH neurons do not express estrogen receptor $\alpha(\mathrm{ER} \alpha)$, the relevant receptor for mediating estradiol feedback [8-10], so other intermediary neurons must convey input from estradiol to GnRH neurons. One set of neurons located within the arcuate nucleus of the hypothalamus (ARC) called KNDy neurons are believed to play an important role in this process. The moniker reflects the coexpression of three neuropeptides, kisspeptin, neurokinin B (NKB) and dynorphin [19]. Kisspeptin neurons express ER $\alpha$, and administration of kisspeptin and NKB stimulates LH secretion in virtually every mammalian species studied to date $[13,15,17,23-25,212,227,228]$. Kisspeptin then acts via its receptor, GPR54, to initiate a pulse of GnRH while NKB acts reciprocally on KNDy neurons via NK3R to release kisspeptin. Conversely, dynorphin inhibits both NKB/kisspeptin release to terminate the pulse [9,31,271]. Based upon such evidence, KNDy neurons have been suggested to play an important role in GnRH pulse generation [271]. While KNDy neurons have been examined in several species [17,19,33-35], they have been virtually unstudied in pigs. 
The purpose of this study was to begin characterizing KNDy neurons in the porcine hypothalamus. We initially examined whether kisspeptin and NKB were expressed (and coexpressed) in the porcine ARC. We then characterized the distribution of the receptor for $\mathrm{NKB}, \mathrm{NK} 3 \mathrm{R}$, in the preoptic area (POA) and the hypothalamus of postpubertal gilts. We also examined whether NK3R was expressed in GnRH neurons. Finally, we examined the effect of a progestin, Altrenogest, on kisspeptin and NKB expression and assessed its effect on activation of KNDy neurons. We report herein that characteristics of the KNDy system in the pig are generally comparable to other species, with notable exceptions being a lack of detectable NK3R expression in the ARC and resistance to inhibition of kisspeptin expression by a progestin.

\section{Materials and Methods}

\section{Animals and Diets}

Experiments were conducted in accordance with the Guide for the Care and Use of Agricultural Animals in Agricultural Research and Teaching [272] and approved by the U.S. Meat Animal Research Center. White, crossbred (Yorkshire x Landrace) postpubertal gilts were used in two replicates. Replicate one $(n=7)$ was performed in 2012 while Replicate two (n=12) was performed in 2015. Gilts were housed individually in pens $\left(1.5 \mathrm{~m}^{2}\right)$ in a climate-controlled facility with 12-hour light/dark cycles (Clay Center, NE). Animals for each replicate were chosen randomly from a single farrowing group. Gilts were part of the normal replacement gilt population but were culled because they had body confirmation issues (i.e. too short-bodied or inadequate leg structure), but were otherwise healthy, normal pigs. Gilts were fed a fortified corn-soybean meal diet (Table 1) twice daily (0800 and $1600 \mathrm{~h})$ that was formulated to meet nutrient requirements [273] and had ad libitum access to water. The amount of feed was adjusted 
based on gilt weight to maintain a daily gain of 0.23 to $0.45 \mathrm{~kg} / \mathrm{d}$.

Table 1. Diet composition, $\%$ as fed.

\begin{tabular}{ll}
\hline Ingredient & Composition \\
\hline Ground corn & 79.08 \\
Soybean meal, 44\% CP & 17.55 \\
Soybean oil & 1.00 \\
Dicalcium phosphate & 0.61 \\
Ground limestone & 0.82 \\
Sodium chloride & 0.30 \\
Vitamin mix ${ }^{1}$ & 0.20 \\
Trace mineral mix ${ }^{2}$ & 0.20 \\
L-Lys & 0.12 \\
Thr & 0.01 \\
BMD & 0.03 \\
Total & 100.00 \\
& \\
Calculated nutrient composition & \\
ME, kcal/kg & \\
CP, \% & 3,388 \\
Calcium, \% & 15.00 \\
Phosphorus, \% & 0.55 \\
Digestible Lys, \% & 0.46 \\
\hline
\end{tabular}

${ }^{1}$ Vitamin A (retinyl acetate), 2,200,000 IU/kg; vitamin $\mathrm{D}_{3}$ (cholecalciferol), 440,000 IU/kg; vitamin E (DL- $\alpha$-tocopheryl acetate), 17,600 IU/kg; vitamin K (menadione sodium bisulfate complex), 2,200 $\mathrm{mg} / \mathrm{kg}$; niacin, 22,000 mg/kg; D-pantothenic acid (D-caliumpanotothenate), $12,100 \mathrm{mg} / \mathrm{kg}$; riboflavin, $4,400 \mathrm{mg} / \mathrm{kg}$; and vitamin $\mathrm{B}_{12}, 22 \mathrm{mg} / \mathrm{kg}$.

${ }^{2}$ Ferrous sulfate heptahydrate, $35.05 \%$; copper sulfate pentahydrate, $1.77 \%$; manganese oxide, $9.62 \%$; calcium iodate, $0.016 \%$; sodium selenite, $0.033 \%$; and calcium carbonate, $50.91 \%$.

${ }^{3}$ Bacitracin methylene disalicylate.

Surgery and Treatments

All gilts were ovariectomized (OVX) via midventral laparotomy. Two to three weeks 
later, a portion (replicate one, $n=4$; replicate two, $n=6$ ) were treated with the progestin, Altrenogest (OVXA), for 10 days. Altrenogest was topdressed in oil over feed at $0.85 \mathrm{mg} / \mathrm{kg}$ body weight twice daily to sufficiently prevent estrus and ovulation in pigs. The second group of gilts (replicate one, $n=3$; replicate two, $n=6$ ) were left untreated and served as OVX controls. In replicate 1 , jugular catheters were in place prior to OVX. In replicate 2, jugular catheters were placed at the time of OVX. On day 9 of both replicates, serial blood samples were collected in SMonovette syringes containing silicate-coated beads (Sarstedt Inc., Newton NC, USA) at 12minute intervals for 6 hours. Serum was separated by centrifugation $\left(2,500 \mathrm{x} g, 20 \mathrm{~min}, 4^{\circ} \mathrm{C}\right)$ and stored at $-20^{\circ} \mathrm{C}$ until used for $\mathrm{LH}$ analysis.

\section{Tissue Collection}

All gilts were euthanized on the 10th day of the treatment with barbiturates according to established guidelines for swine [274]. The head was removed and transported to a fume hood for perfusion. The carotid arteries were cannulated with 16-ga blunt end needles and the head was bilaterally perfused with $6 \mathrm{~L}$ of $4 \%$ paraformaldehyde (PAF) pumped at a rate of $1 \mathrm{~L}$ per 5 min (MasterFlex L/S pump). A block of tissue containing the hypothalamus and POA was removed and placed in 500-700 $\mathrm{mL}$ of $4 \%$ PAF overnight at $4{ }^{\circ} \mathrm{C}$ while subjected to agitation on a rocking platform. The next day, PAF was replaced with $20 \%$ sucrose in PBS and tissue was stored at $4^{\circ} \mathrm{C}$ until the blocks of tissue sank. A freezing microtome was used to cut tissue blocks into $50 \mu \mathrm{m}$ sections. Every 5 th section was collected and vials were separated into either the $\mathrm{MBH}$ or POA and stored in cryoprotectant at $-20^{\circ} \mathrm{C}$ until use. Tissue was subjected to immunohistochemistry to assess the distribution of, and effect of Altrenogest on, kisspeptin, NKB, and NK3R as described below. 


\section{Tissue Analysis}

\section{$\underline{\text { Kisspeptin }}$}

To assess the distribution of kisspeptin-containing cells within the ARC and to examine the effect of Altrenogest on kisspeptin cell numbers, 3-4 tissue sections were collected from the rostral, medial and caudal ARC of OVXA ( $n=4$, replicate one; $n=6$, replicate two) or OVX ( $\mathrm{n}=3$, replicate one; $n=6$, replicate two) gilts. Regions of the ARC were determined by the shape of the infundibular stalk and location of the fornix and mammillothalamic tract. On day 1 of the protocol, sections were washed $4 \times 5$ min in $0.1 \mathrm{M}$ phosphate-buffered saline (PBS; $\mathrm{pH} 7.4$ ) to remove excess cryoprotectant and stored overnight at $4^{\circ} \mathrm{C}$. The next day, sections were washed $4 \times 5$ min in PBS, placed in $1 \% \mathrm{H}_{2} \mathrm{O}_{2}$ for $10 \mathrm{~min}$, and subsequently washed $4 \times 5$ min in PBS. Tissue was then incubated for at least $1 \mathrm{hr}$ in a blocking solution containing PBS, $0.4 \%$ Triton X100 (PBST; Sigma-Aldrich, St. Louis, MO, USA) and 20\% normal goat serum (NGS; Jackson ImmunoResearch Laboratories, Inc., West Grove, PA, USA). Sections were then incubated with rabbit anti-kisspeptin serum (Cat\# AB9754; 1:2,000; Millipore Sigma, Billerica, MA, USA) in PBST with 4\% NGS at room temperature for $\sim 16 \mathrm{hr}$. After incubation, sections were washed 4x5 min in PBS and then incubated with biotinylated goat anti-rabbit IgG (Cat\# BA-1000; 1:400; Vector Laboratories, Burlingame, CA, USA) in PBST, with 4\% NGS for $1 \mathrm{hr}$. The sections were washed 4x5 min and incubated with streptavidin horseradish-peroxidase conjugate (Vectastain Elite ABC; 1:600; Vector Laboratories) for $1 \mathrm{hr}$. Sections were then washed 4x5 min and incubated in a solution containing 3,3-diaminobenzidine (DAB; $10 \mathrm{mg}$; Cat\# D5905 SigmaAldrich) as a chromagen and $25 \mu \mathrm{l}$ hydrogen peroxide (30\% stock; Sigma-Aldrich) in $0.1 \mathrm{M}$ phosphate buffer (PB; pH 7.4) for $10 \mathrm{~min}$. The sections were washed, mounted on Superfrost microscope slides (Fisher Scientific, Pittsburgh, PA, USA), allowed to dry and cover slipped using Eukitt Mounting Reagent (Fisher Scientific). 
We subsequently assessed whether Altrenogest reduced the activity of kisspeptin neurons using c-Fos as an index of neuronal activation. Six hemi-sections of tissue were taken from OVX $(n=4)$ and OVXA $(n=4)$ gilts from replicate two encompassing the rostral, middle and caudal ARC (2 hemi-sections per area per animal). This tissue was stained using DAB as the chromogen for cytoplasmic staining of kisspeptin and DAB conjugated to Nickel as the chromogen for staining of c-Fos in the cell nucleus. On day 1 , sections were washed $4 \times 5$ min in $0.1 \mathrm{M}$ phosphate-buffered saline (PBS; $\mathrm{pH} 7.4$ ) and stored overnight at $4^{\circ} \mathrm{C}$. The next day, sections were washed $4 \times 5$ min in PBS, placed in $1 \% \mathrm{H}_{2} \mathrm{O}_{2}$ for $10 \mathrm{~min}$, and subsequently washed $4 \times 5$ min in PBS. Tissue was then incubated for at least $1 \mathrm{hr}$ in a blocking solution containing PBS, $0.4 \%$ Triton X-100 (PBST; Sigma-Aldrich, St. Louis, MO, USA) and 20\% normal goat serum. Next, sections were incubated in a solution containing rabbit anti-c-Fos (1: 1,000; Cat \# SC253; Santa Cruz) for $\sim 16 \mathrm{hr}$ at room temperature. After incubation, sections were washed $4 \times 5$ min in PBS and then incubated in a solution containing biotinylated goat anti-rabbit IgG (Cat\# BA1000;1:400; Vector Laboratories, Burlingame, CA, USA), PBST, and 4\% NGS for $1 \mathrm{hr}$. The sections were washed $4 \times 5$ min and incubated in a solution containing streptavidin horseradishperoxidase conjugate (Vectastain Elite ABC; 1:600; Vector Laboratories) for $1 \mathrm{hr}$. Sections were then washed and incubated in a solution containing DAB (10 mg; Cat\# D5905 Sigma-Aldrich), 2 $\mathrm{ml}$ of Nickel Sulfate solution ( $2 \%$ stock in ddH2O) and $25 \mu 1$ hydrogen peroxide (30\% stock; Sigma-Aldrich) in PB for 10 min. After 4x5 min PBS washes, the tissues were placed in $1 \%$ $\mathrm{H}_{2} \mathrm{O}_{2}$ for 10 minutes and subsequently washed $4 \times 5$ mins in PBS. The tissues are blocked in $20 \%$ NGS with PBST for $1 \mathrm{hr}$ and incubated overnight at room temperature ( 16 hr) with rabbit antikisspeptin antiserum (Cat\# AB9754; 1:2,000; Millipore Sigma, Billerica, MA, USA) in PBST and $4 \%$ NGS at room temperature. The remaining steps are identical to the procedure for staining 
kisspeptin using $\mathrm{DAB}$ as described above.

$\underline{\mathrm{NKB}}$

To assess NKB cell distribution, cell numbers and the effect of Altrenogest, a DAB staining protocol similar to that employed for kisspeptin was used on OVX (n=3) and OVXA $(n=4)$ gilts from replicate one. In this protocol, the primary antibody was rabbit anti-NKB (Novus Biologicals, Littleton, $\mathrm{CO}$ ) and the required blocking solution used was 4\% NGS instead of the $20 \%$ NGS needed for kisspeptin staining. All incubation times and temperatures were the same as previously stated.

Dual-label immunofluorescence was used to assess the degree to which kisspeptin and NKB colocalize in the ARC of the OVX pig. Three ARC sections per OVX animal from replicate one $(n=3)$ were washed $4 \times 5$ min and placed in $10 \% \mathrm{H}_{2} \mathrm{O}_{2}$ with PBS for 10 minutes. Tissue was blocked in 20\% NGS and PBST for $1 \mathrm{hr}$ and then incubated with rabbit antikisspeptin (1:50,000; Lot\# 564; Gift from Professor Alain Caraty, France) for $~ 16 \mathrm{hr}$ at room temperature. The following day, tissue was washed $4 \times 5$ min in PBS, incubated in biotinylated goat anti-rabbit secondary antibody (Cat\# BA-1000; 1:400; Vector Laboratories, Burlingame, CA, USA) for $1 \mathrm{hr}$ and then washed $4 \times 5 \mathrm{~min}$ in PBS. Tissue was then placed in Vectastain Elite $\mathrm{ABC}$ for $1 \mathrm{hr}$, washed, and then incubated in a solution of Biotinyl-Tyramide (1:250; Cat\# NEL700A; Perkin Elmer; Waltham, MA, USA) with 3\% $\mathrm{H}_{2} \mathrm{O}_{2}\left(1 \mu 1 \mathrm{H}_{2} \mathrm{O}_{2} / \mathrm{ml}\right.$ solution) for $10 \mathrm{~min}$. After washing, sections were developed with Alexa 555 conjugated to streptavidin (1:100, Fisher Scientific) diluted in PBS for 30 min, washed in PBS and then incubated with guinea pig antiNKB (1: 1,000; Gift from Dr. Philippe Cioffi, INSERM, Bordeaux, FR) in NGS and PBST for $\sim 16 \mathrm{hr}$ at room temperature. Tissue was washed $4 \times 5 \mathrm{~min}$, incubated for $1 \mathrm{hr}$ in anti-guinea pig Alexa 488 (1:100; Life Technologies, Carlsbad, CA, USA) with NGS and PBST and washed again before mounting and cover slipping with Gelvatol. Colocalization of NKB and kisspeptin 
was performed by Dr. Chrysanthi Fergani in the laboratory of Dr. Michael Lehman.

$\underline{\text { NK3R }}$

To analyze the distribution of NK3R-containing cells, tissue was blocked with $4 \%$ normal goat serum then incubated for $1 \mathrm{hr}$ with rabbit anti-NK3R (1:20,000; Cat\# 300-102; Novus Biologicals, Littleton, CO, USA) as the primary antibody. The rest of the protocol was identical to the DAB immunostaining described previously. The tissue sections were selected in series spanning the entire POA and hypothalamus using OVX gilt tissue $(n=3)$ from replicate two.

Dual label immunofluorescence was used to ascertain whether GnRH neurons express NK3R or are apposed by NK3R-containing close-contacts. Immunofluorescent staining for NK3R was similar to that described above (rabbit anti-NK3R, 1:1,000; Novus Biologicals, Littleton, CO, USA), but with the addition of dual incubation with mouse anti-GnRH antibody (1:1,000; MyBioSource; San Diego, CA, USA) for $\sim 16 \mathrm{hr}$ at room temperature. The next day, sections were washed 4x5 min in PBS and then incubated with anti-rabbit Alexa 555 (1:200; Life Technologies, Carlsbad, CA, USA) in 4\% NGS and PBST for $1 \mathrm{hr}$ followed by $4 \times 5$ min washes. The tissue was next incubated in goat anti-mouse DyLight Green (1:200, Fisher Scientific) and 4\% NGS with PBST. All tissue sections were washed 4x5 min with PBS, mounted on slides to dry and cover-slipped with Gelvatol. Slides were stored in the dark at $4^{\circ} \mathrm{C}$. To determine whether NK3R apposed GnRH neurons, NK3R-positive contacts were counted using $10 \mathrm{GnRH}$ neurons that were randomly chosen in 3 to 4 medial POA sections from OVX $(n=3)$ and OVXA $(n=3)$ gilts of replicate two.

To assess the influence of Altrenogest on NK3R-positive cell numbers within the POA and specific areas of the hypothalamus known to be important for reproduction, tissue from the PVN, RCh, POA and ARC was selected from OVX (n=6) or OVXA (n=6) gilts of replicate two. 
Single-label immunofluorescence was used to assess NK3R-containing cell numbers. The protocol was described above for NK3R DAB staining except the dilution of the rabbit antiNK3R (Cat\# 300-102; Novus Biologicals, Littleton, CO, USA) was 1:1,000. After incubation, sections were washed $4 \times 5$ min in PBS and then incubated with biotinylated goat anti-rabbit $\operatorname{IgG}$ (Cat\# BA-1000; 1:400; Vector Laboratories, Burlingame, CA, USA) in PBST and 4\% NGS for 1 hr. The sections were washed, incubated for $1 \mathrm{hr}$ with anti-rabbit DyLight green (Cat\# 35503; 1:200; ThermoFisher Scientific) in PBS, and then covered with foil to avoid exposure to light. After a final wash (4x5 min in PBS) tissue was mounted on Superfrost microscope slides (Fisher Scientific, Pittsburgh, PA, USA), allowed to dry and cover-slipped with Gelvatol and stored in the dark at $4^{\circ} \mathrm{C}$.

\section{Data Analysis}

Luteinizing Hormone

Concentrations of LH in serum were determined in serial samples by a porcine-specific RIA [77]. For the first replicate, a previously validated radio-immunoassay was used to measure LH in duplicate aliquots of plasma and expressed in terms of AFP-10506A. Reagents were provided by the National Hormone and Peptide Program (Torrance, CA, USA). Assays had a minimal LH detectability of $0.08 \mathrm{ng} / \mathrm{mL}$. Pools of porcine serum with LH concentrations of 0.2 , 1.0 and $4.5 \mathrm{ng} / \mathrm{mL}$ had an average intra-assay $\mathrm{CV}$ of $8.9 \%$. LH values for replicate two are pending.

To determine the presence of a $\mathrm{LH}$ pulse in serum, three criteria had to be met. The amplitude of the pulse had to be greater than the sensitivity; The peak had to occur within two samples of the nadir; and the LH concentration at said peak had to exceed the $95 \%$ confidence limits (based on overall assay variability) by being greater than two standard deviations above 
the concentration for the preceding and subsequent nadir (Goodman and Kasch, 1980). Mean LH, LH pulse amplitude and inter-pulse intervals (IPI) were compared between OVX and OVXA gilts using Student's t-test. The number of pulses per group over the $4.6 \mathrm{hr}$ time frame was compared using the Mann-Whitney U test.

Immunocytochemistry

Immunopositive cells were imaged and counted using either an Olympus VS120 SlideScanning, Zeiss Upright Fluorescence or Zeiss Violet Confocal microscope. Kisspeptin and NKB distribution, cell counts and the percentage of kisspeptin cells coexpressing c-Fos immunostaining was visualized on an Olympus VS120 Slide Scanning microscope. Total number of kisspeptin-immunopositive cells per animal and the effect of Altrenogest on cell numbers were calculated from gilts of replicate one and two. Replicate one averaged three tissue sections from each gilt in OVX $(n=3)$ and OVXA $(n=4)$ groups while replicate two averaged four sections from OVX $(n=6)$ and OVXA $(n=6)$ animals. The total number of cells for each gilt was counted in a manner that was blind to treatment using Olympus software (OlyVIA). The average of the total cell counts per animal for each group was compared by Student's t-test with $\mathrm{p}<0.05$ considered significant and $0.1>\mathrm{p}>0.05$ considered to be a trend. A one-way analysis of variance was used to examine differences in kisspeptin cell numbers between the rostral, medial, and caudal ARC of OVX $(n=4)$ or OVXA $(n=4)$ gilts from replicate two. The percentage of kisspeptin neurons expressing c-Fos was assessed and analyzed by chi-square analysis.

Distribution of NK3R-containing cells was determined by staining a series of sections from OVX gilts $(n=3)$ from replicate two throughout the POA and hypothalamus. Images were obtained using an Olympus VS120 Slide Scanning microscope. Total cell counts were obtained per gilt for the DBB, POA, PeV, PVN, SON, RCh and ARC. The average cell counts for each section were calculated using total cell counts from all three gilts within each area. Differences 
between areas were analyzed by ANOVA and Tukey HSD. Assessment of the effect of Altrenogest on numbers of NK3R-containing cells in the POA, RCh, PVN and ARC were obtained from images processed by an Olympus V120 Slide Scanning microscope. Cell counts per section were performed for OVX $(n=6)$ or OVXA $(n=6)$ from replicate two within each of the aforementioned brain areas. Total counts per animal in each area were averaged and compared between OVX and OVXA gilts by Student's t-test.

Identification of co-localization and close contacts between NK3R and GnRH neurons, and assessment of the effects of Altrenogest on numbers of close contacts, was performed using tissue from OVX $(n=6)$ and OVXA $(n=6)$ gilts of replicate two. To determine the percentage of GnRH neurons that coexpressed NK3R, images were captured using an Upright LSM 510 Violet Confocal (Zeiss) microscope with a Plan Apochromat x 63/1.4 oil objective. For assessment of close contacts, confocal Z-stacks of $1 \mu \mathrm{m}$ intervals were taken from 9 to $10 \mathrm{GnRH}$ neurons randomly selected from 3 to 4 medial POA sections for OVX (n=4) and OVXA (n=4) animals of replicate two. Each contact was analyzed using Zeiss Zen software. Orthogonal views were used to confirm that contacts were touching in all planes. The average number of contacts per GnRH neuron was calculated for each animal and analyzed by Student's t-test. A chi-square analysis compared the percentage of GnRH neurons in each group that expressed these contacts.

\section{Results}

\section{LH Data}

The oral administration of the progestin, Altrenogest, had an inhibitory effect on mean circulating concentrations of LH (Figure 1A; $0.70 \pm 0.23 \mathrm{ng} / \mathrm{mL}$ vs. $1.58 \pm 0.21 \mathrm{ng} / \mathrm{mL}$ ) as well as the number of LH pulses per 4.6 hours (Figure 1D; $2.25 \pm 0.29$ vs. $5.33 \pm 1.20$ for OVXA and OVX gilts, respectively). The inter-pulse interval (IPI) and amplitude of LH pulses did not differ 
between treatments (Figure 1B and 1C). Representative LH profiles for an OVX and an OVXA gilt are shown in Figure 2.
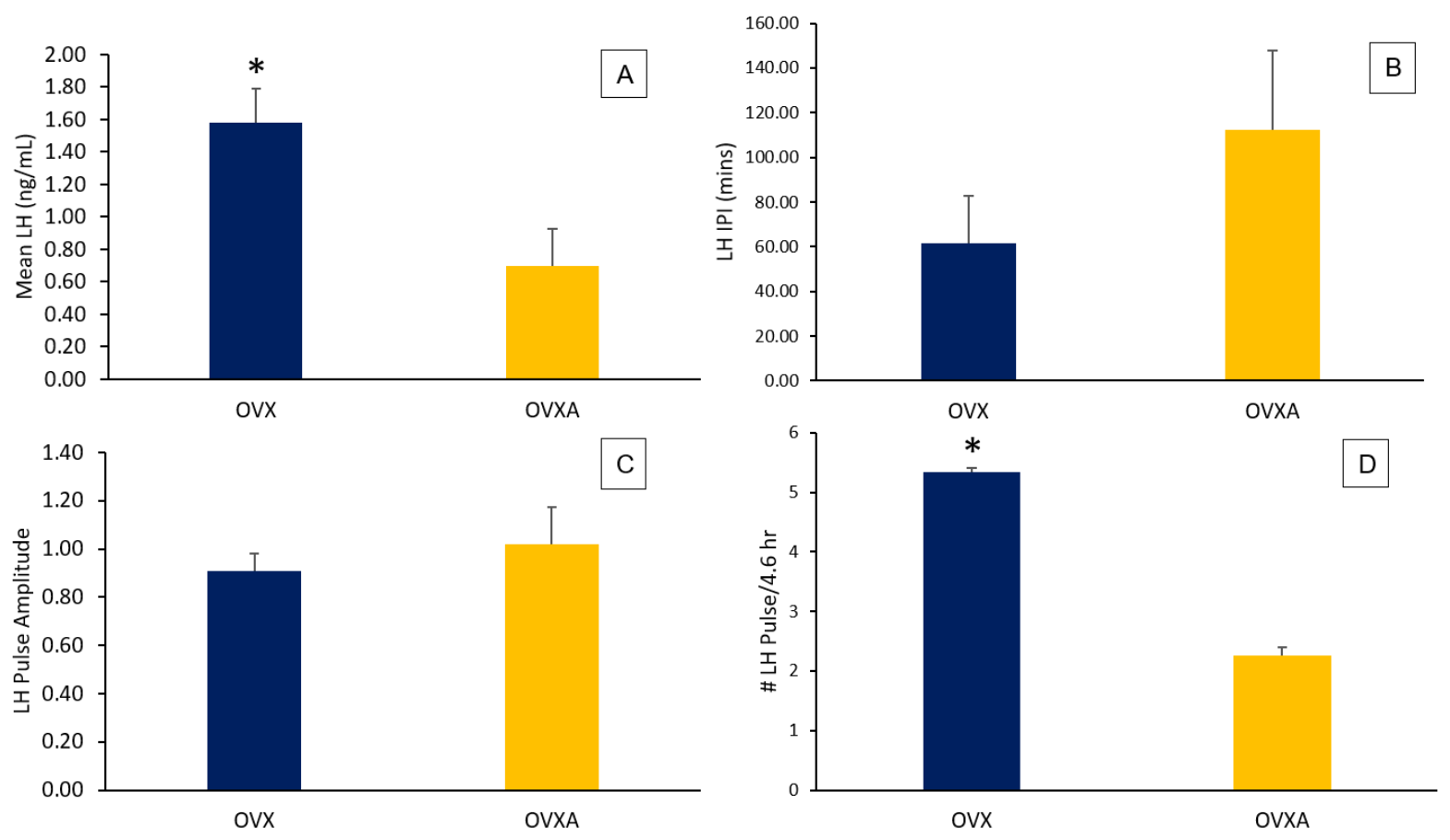

Figure 1: Mean ( \pm SEM) concentrations of $\mathrm{LH}(\mathrm{A}), \mathrm{LH}$ inter-pulse interval (B), LH pulse amplitude (C), and LH pulse frequency (D) for OVX (blue bars) and OVXA (yellow bars) gilts. Asterisk indicates significance between groups ( $p<0.05)$. 

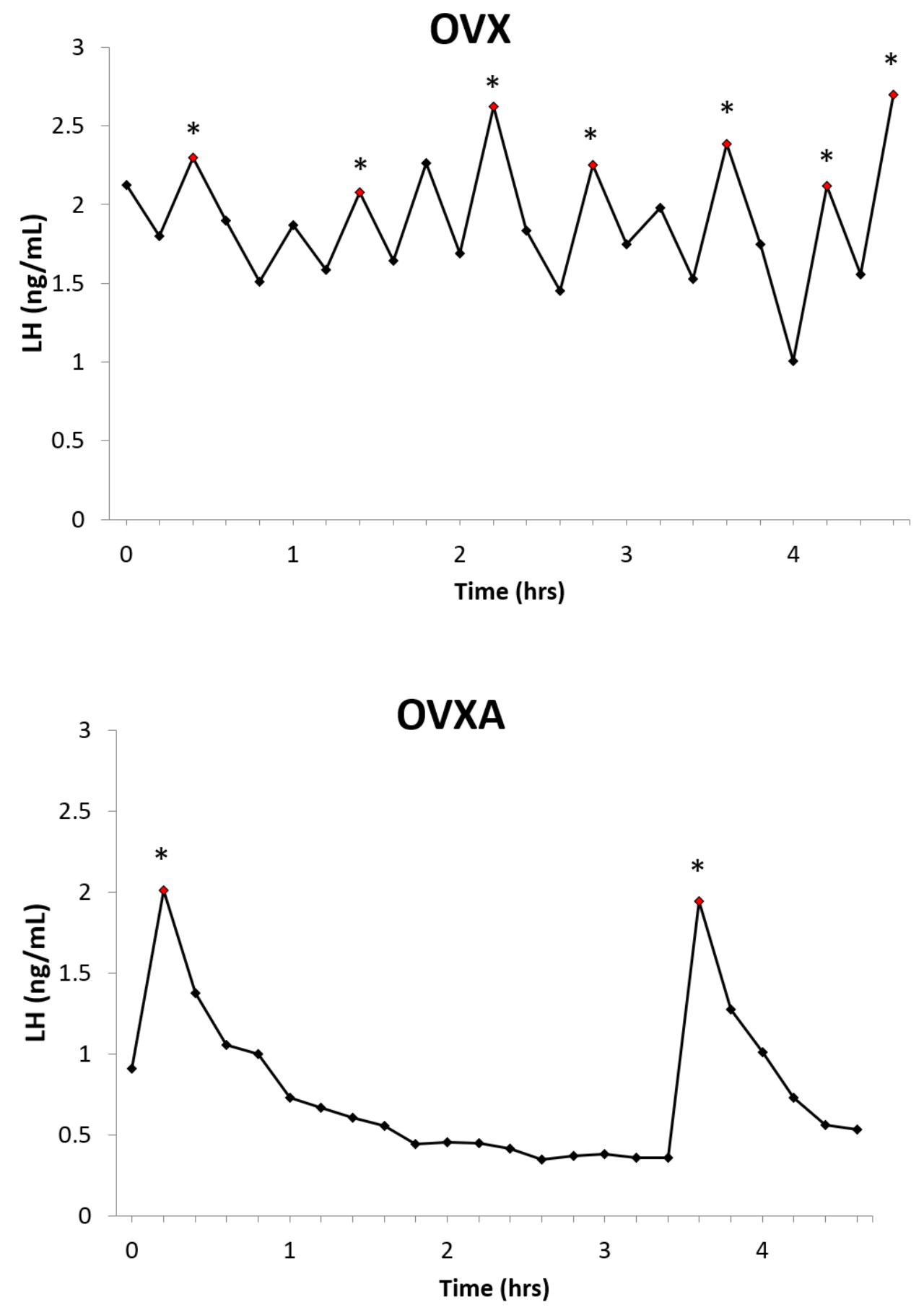

Figure 2: Representative LH profiles for an OVX (top) and OVXA gilt (bottom). Asterisks indicate LH pulses. 


\section{Kisspeptin}

Kisspeptin was observed in the ARC of both OVX and OVXA gilts. Kisspeptin cells were largely localized to the dorsal portion of the ARC (Figure 3). Kisspeptin cell numbers within regions of the ARC are shown in Figure 4. When all gilts were considered regardless of treatment, there was a greater number of kisspeptin cells in the rostral $(173 \pm 59.76)$ or middle region $(224 \pm 34.9)$ than the caudal $(30 \pm 8.40)$ region of the ARC ( $\mathrm{p}<0.05)$. With regard to an effect of Altrenogest, an increase in kisspeptin cell numbers for OVXA versus OVX gilts was found in the middle region $(281 \pm 40.18$ vs. $167 \pm 39.97 ; \mathrm{p}=0.038)$ whereas the number of kisspeptin cells in the rostral and caudal ARC did not differ with treatment.

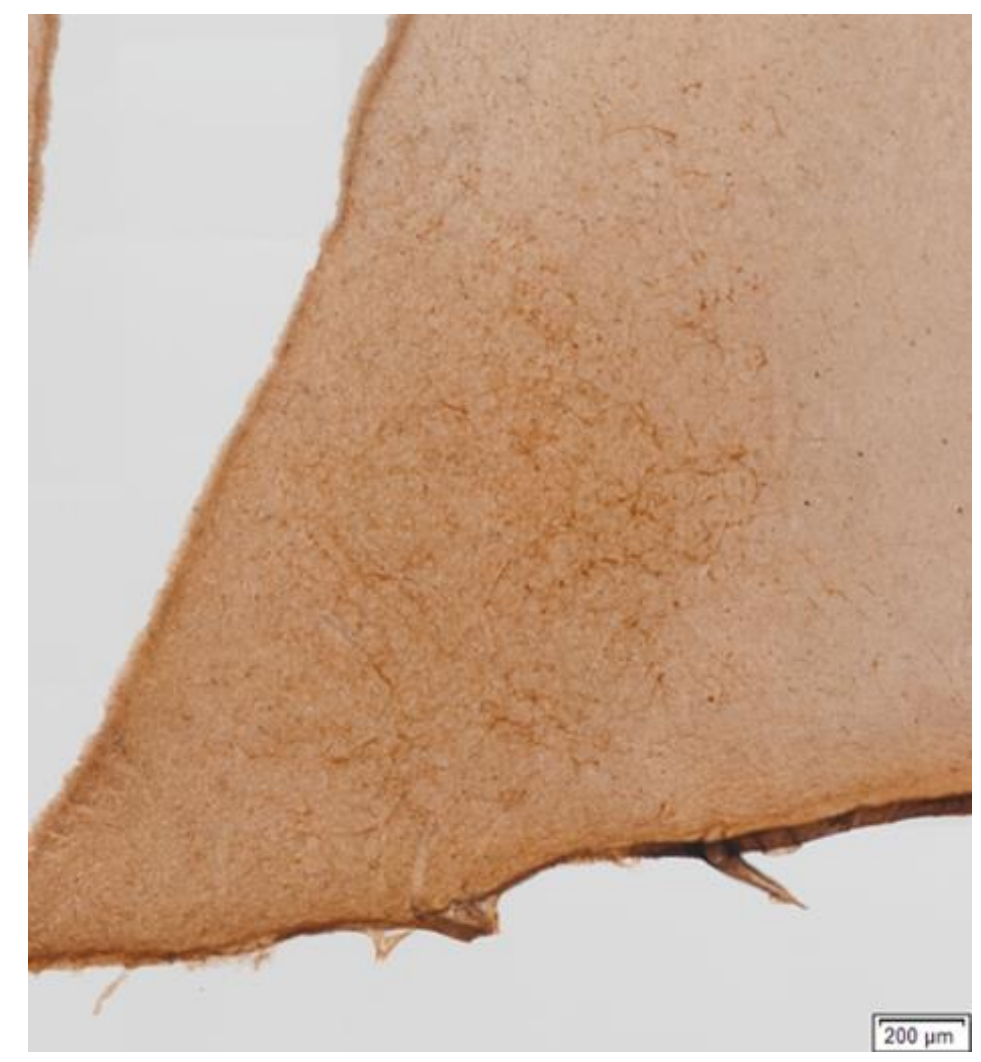

Figure 3: Representative photomicrograph of kisspeptin staining within the porcine ARC. 


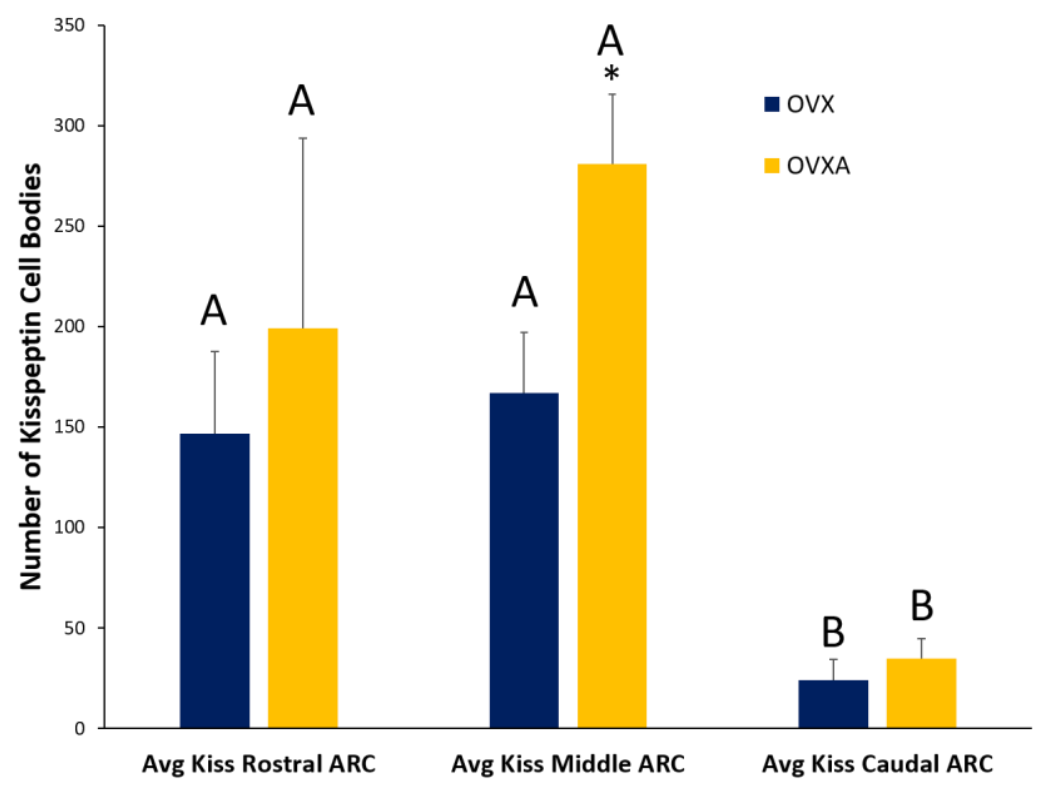

Figure 4: Mean $( \pm$ SEM) numbers of kisspeptin-positive cells in the rostral, middle and caudal ARC of OVX and OVXA gilts. Different letters indicate differences between regions of ARC ( 1 < 0.05$)$. Asterisk indicates differences between OVXA and OVX groups $(\mathrm{p}<0.05)$.

Kisspeptin cell numbers in the first replicate (Figure 5A) tended $(\mathrm{p}=0.09)$ to be higher in the OVXA gilts versus OVX gilts. The second replicate (Figure 5B) produced similar results with a similar trend $(\mathrm{p}=0.09)$ for kisspeptin cell numbers to be higher in the OVXA gilts. 

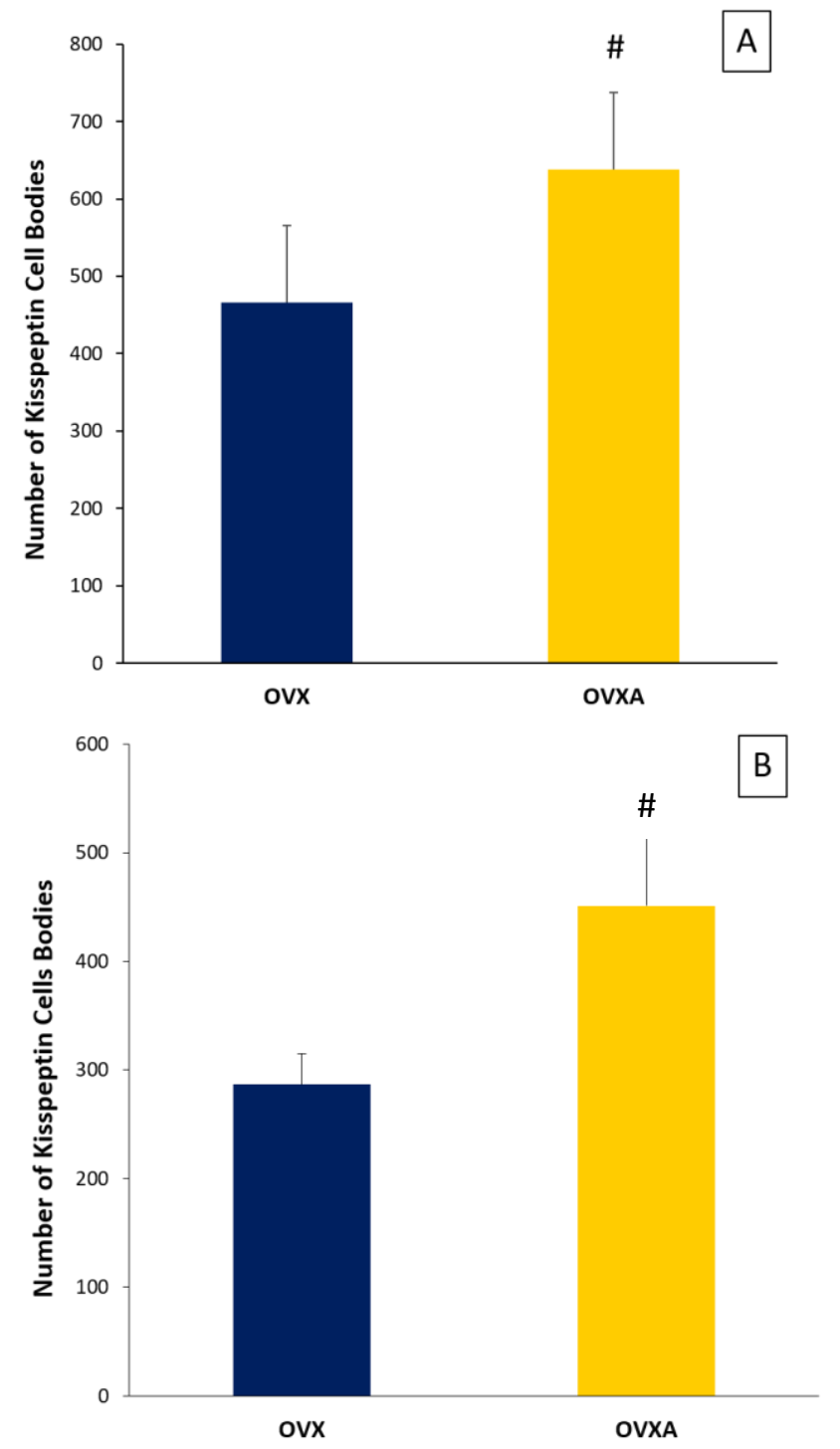

Figure 5: Mean ( \pm SEM) kisspeptin cell numbers within the ARC of OVX and OVXA gilts from replicate one (A) and replicate two (B). Number symbol indicates a trend (p $=0.09$ ).

The presence of c-Fos was observed in kisspeptin cells (Figure 6). The percentage of kisspeptin cells stained with c-Fos tended $(\mathrm{p}=0.08)$ to be greater in OVX than OVXA gilts $(10.5 \pm 2.7 \%$ vs. $5.6 \pm 3.0 \%)$ (Table 2$)$. 


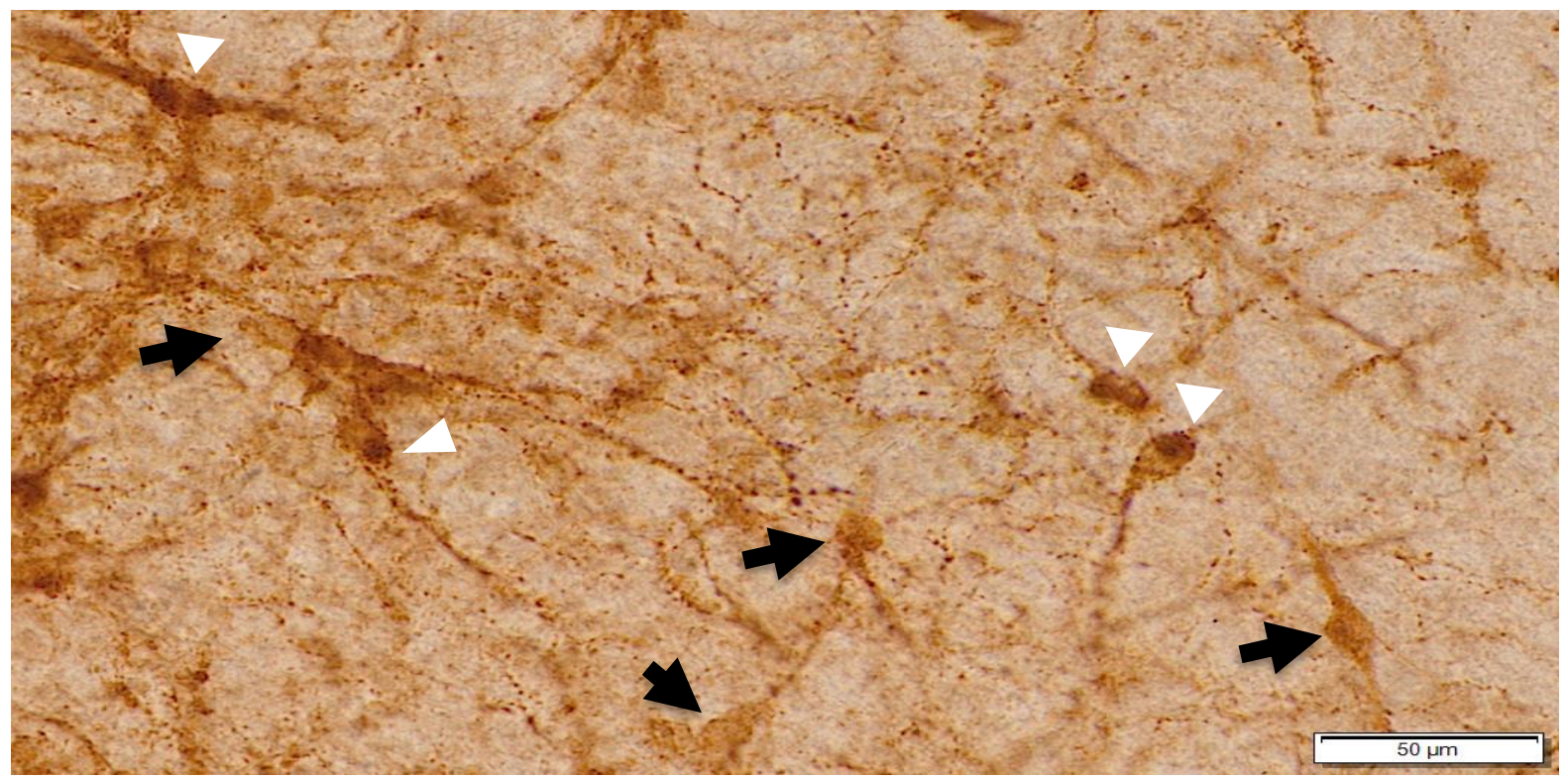

Figure 6: A 20x photomicrograph of ARC kisspeptin cells with nuclear DAB/Nickel staining for c-Fos as an index of neuronal activation. White arrow heads point to kisspeptin cells that are positive for c-Fos staining; Black arrows point to kisspeptin cells lacking c-Fos staining.

Table 2: Mean ( \pm SEM) numbers and proportion of kisspeptin cells within the arcuate nucleus (ARC) expressing nuclear c-Fos staining, an indicator of neuronal activation, in ovariectomized (OVX) gilts and OVX gilts treated with the progestin, Altrenogest, (OVXA).

\begin{tabular}{|l|l|l|l|l|}
\hline Area & Group & No. of Kiss Cells & No. of Kiss Cells with c-Fos & $\%$ Kiss/c-Fos cells \\
\hline \multirow{2}{*}{ ARC } & OVX & $338 \pm 36.7$ & $36 \pm 5.9$ & $10.5 \pm 2.7 *$ \\
\cline { 2 - 5 } & OVXA & $515 \pm 92.2$ & $29 \pm 15.8$ & $5.6 \pm 3.0$ \\
\hline$* p=0.08$ & & \\
\hline
\end{tabular}

$N K B$

The number of NKB cells were quantified for the first replicate (Figure 7). The number of NKB-positive cells in the ARC did not differ with treatment. 


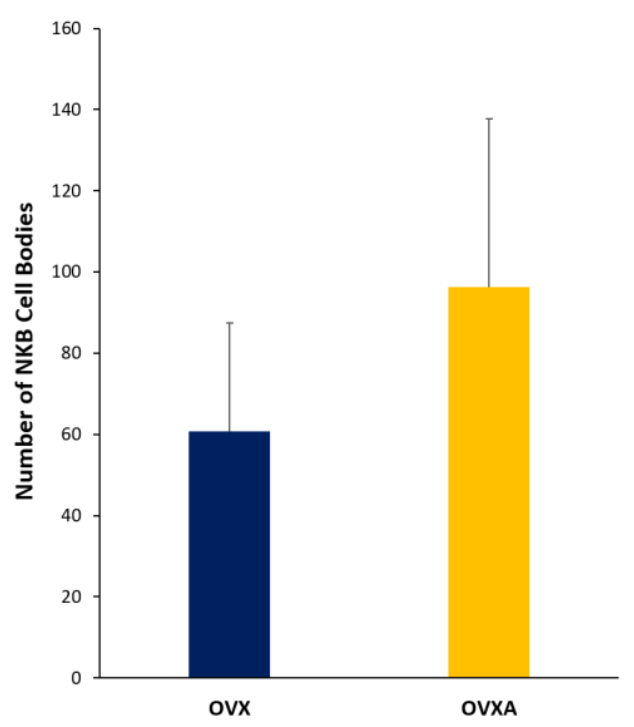

Figure 7: Mean ( \pm SEM) NKB cell numbers in the ARC of OVX and OVXA gilts. Cell numbers were not statistically different.

Tissue from 3 gilts was used to determine if kisspeptin and NKB are coexpressed in the ARC. Dual immunofluorescence for kisspeptin and NKB (Figure 8) showed a high percentage of co-localization between the two populations of peptides, with virtually all (99-100\%) kisspeptin neurons co-expressing NKB and $92 \%$ of NKB neurons coexpressing kisspeptin.

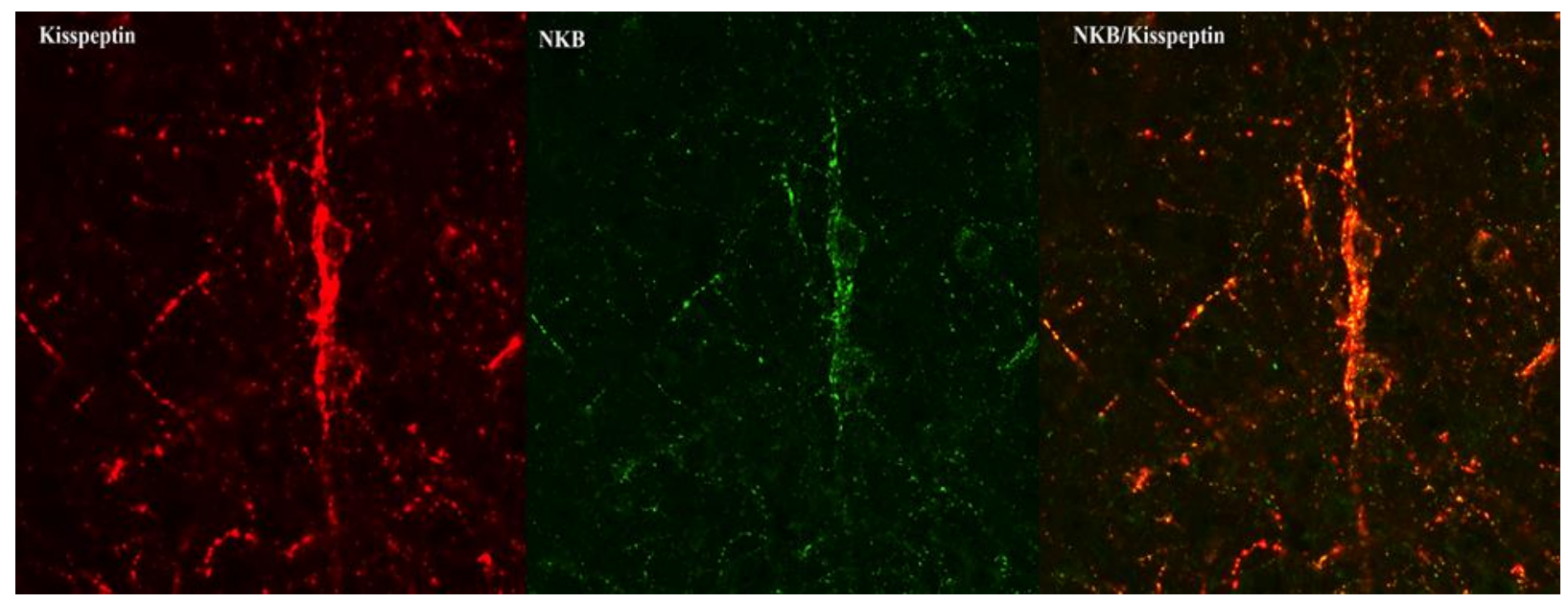

Figure 8: Coexpression of kisspeptin and NKB in the ARC. Dual 
immunofluorescence (viewed at 60x) for two neurons in the ARC expressing kisspeptin (red, left panel) and NKB (green, middle panel). The merged image in the right panel clearly demonstrates colocalization of the two peptides.

NK3R

NK3R-containing cells were distributed throughout the POA and hypothalamus. Cells were distinguishable via their cytoplasmic staining in all areas except for the ARC. The average number of NK3R cells ranged from 150-900 cells in the DBB, POA, SON, PeV, PVN, and RCh with numbers being highest in the DBB and PVN (Figure 9). No cells or fibers were evident within the ARC.

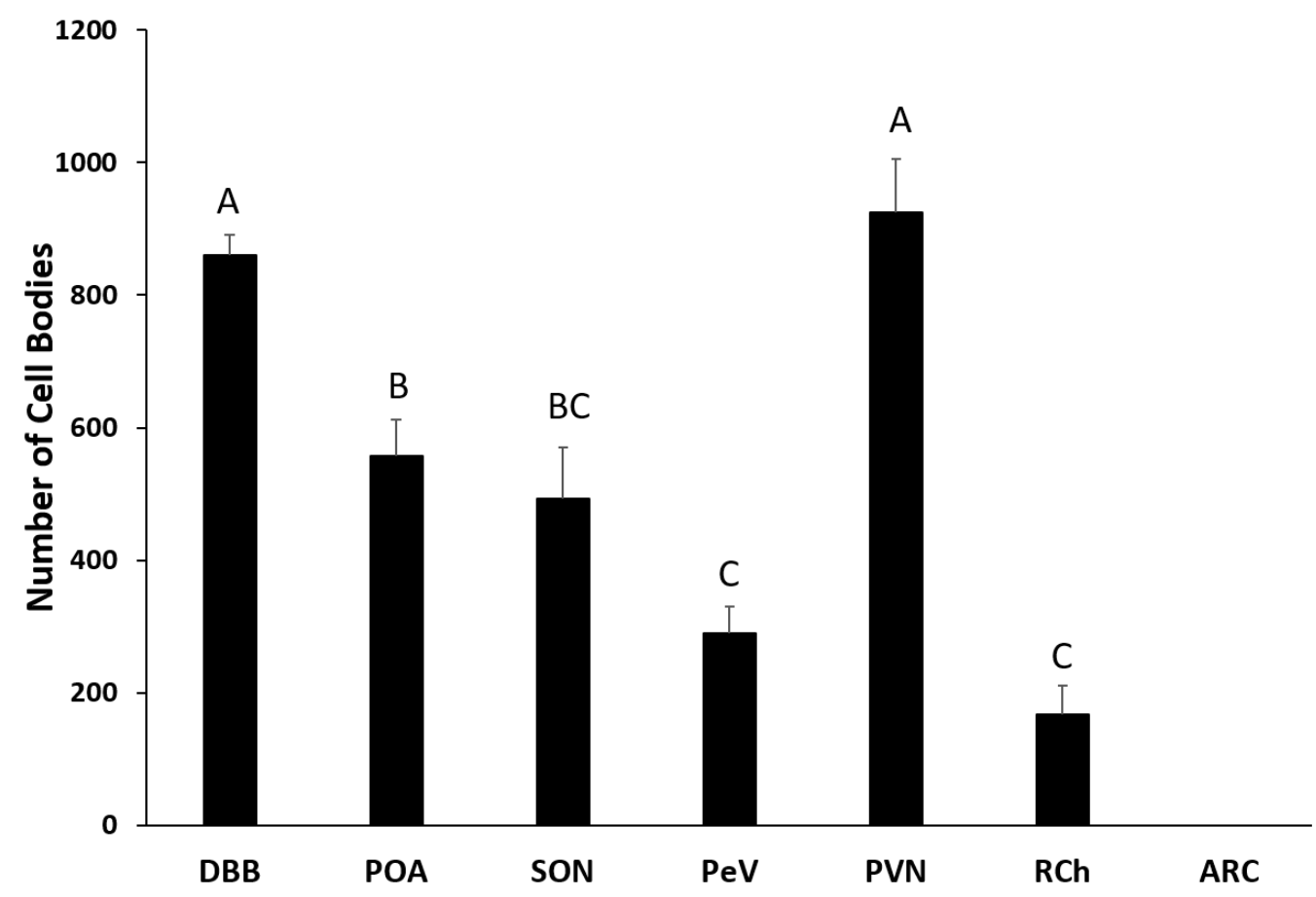

Figure 9: Mean ( \pm SEM) NK3R-immunopositive cell numbers throughout the POA and hypothalamus in OVX gilts $(n=3)$. Different letters indicate significance between regions $(\mathbf{p}<0.05)$. 
We examined $10 \mathrm{GnRH}$ neurons in each of 4 OVX and 4 OVXA gilts from replicate two. In no case did we see a GnRH neuron that coexpressed NK3R, even though NK3Rimmunopositive neurons were clearly evident in close proximity to GnRH neurons (Figure 10). We found that $41 \%$ of GnRH neurons were contacted by NK3R-positive appositions, albeit the average number of NK3R-positive close-contacts associated with each GnRH-positive neuron was low (1.0 $\pm 0.3 ;$ Figure 11).
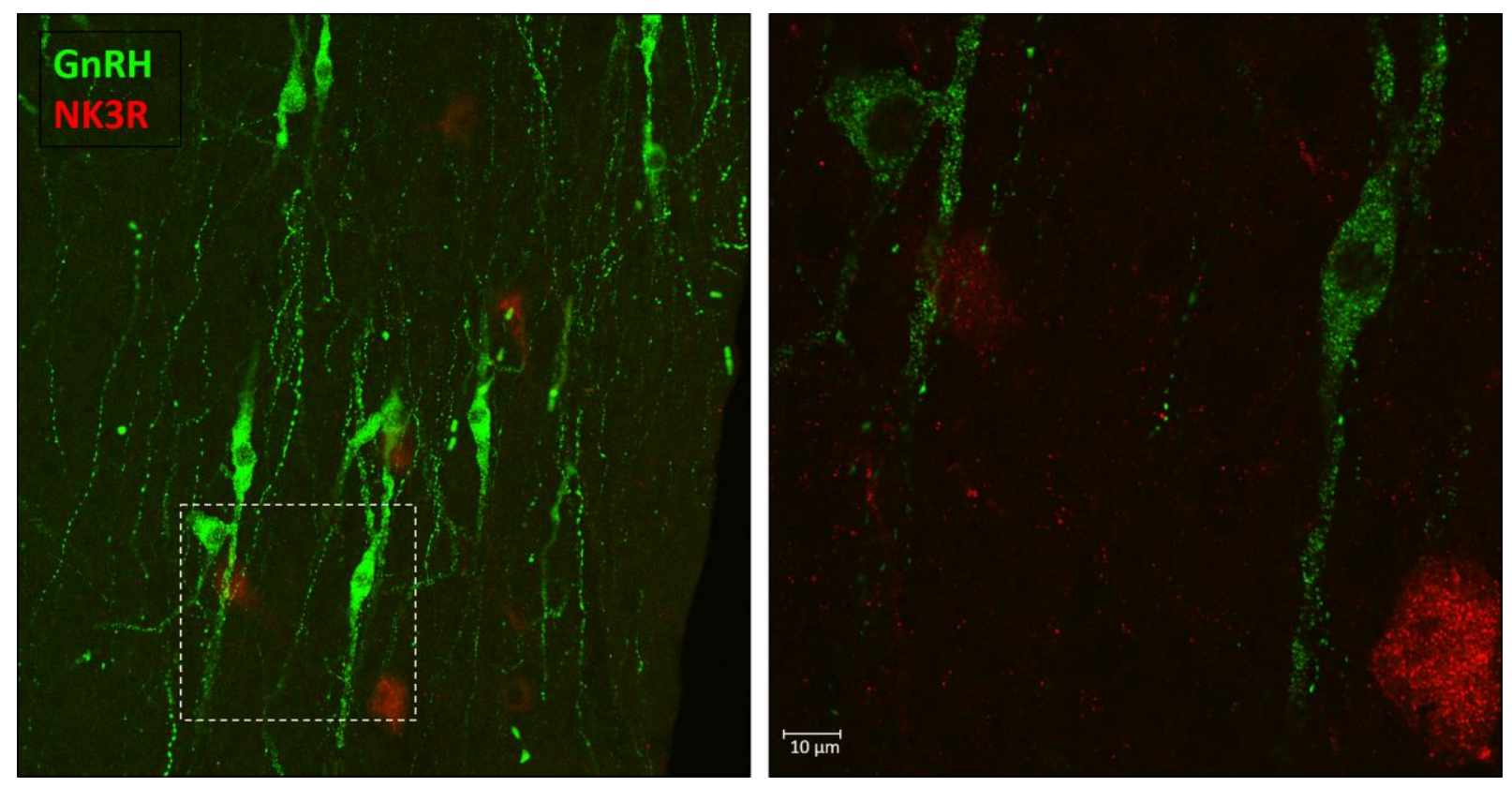

Figure 10: Lack of NK3R coexpression with GnRH neurons. A representative photomicrograph of GnRH (green) and NK3R-containing (red) neurons using dual-label immunofluorescence in the POA of the pig hypothalamus (63x). 

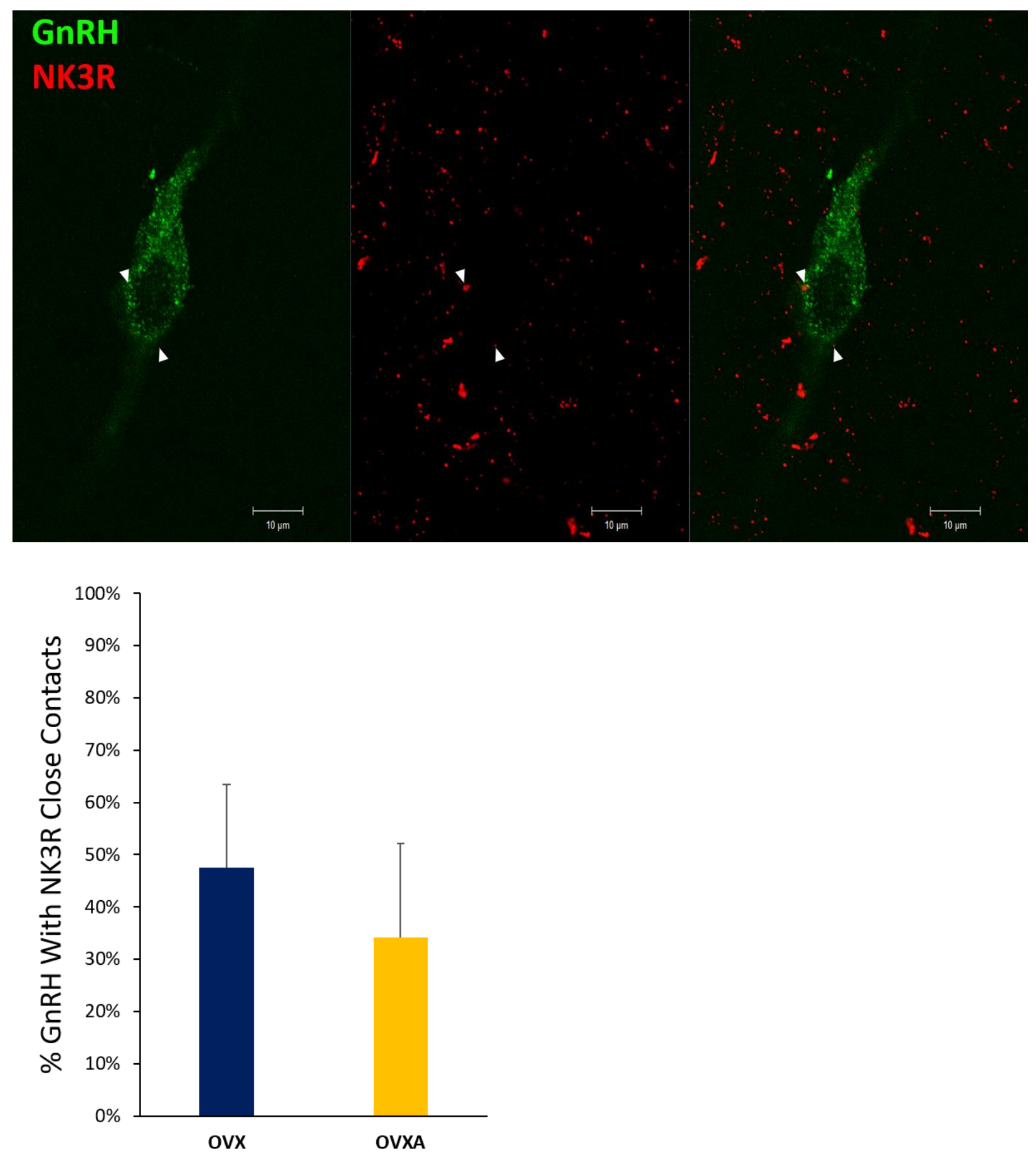

Figure 11: Top) A photomicrograph (63x) of NK3R immunopositive contacts (red, middle panel) on GnRH neurons (green, left panel) using dual-label immunofluorescence in the POA. In the merged image (right panel), white arrow 
heads point to close contacts. Bottom) The proportion of GnRH neurons in the POA closely apposed by NK3R-containing contacts. There was no difference between treatment groups.

The effect of Altrenogest on the number of cell containing NK3R was quantified for replicate two within the POA, PVN, RCh, and ARC (Figure 12). NK3R-containing cells were observed within the POA, PVN and RCh in both OVX and OVXA gilts, but the number of cells in these hypothalamic areas did not differ with Altrenogest treatment. NK3R-positive cells were not observed in the ARC nor did treatment with Altrenogest produce any detectable NK3R staining (Figure 13).

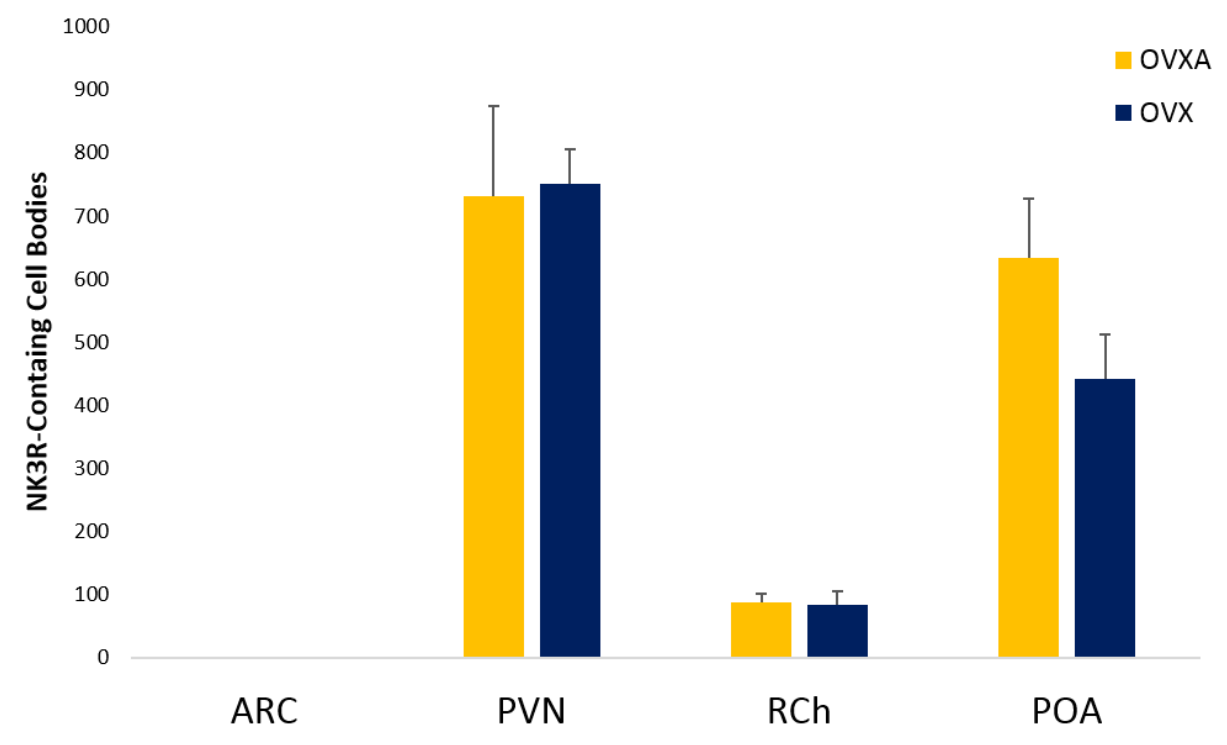

Figure 12: Effect of Altrenogest on mean $( \pm$ SEM) NK3R-containing cell numbers in the PVN, RCh and POA. There was no significant difference in cell numbers between OVX or OVXA gilts for any area. 

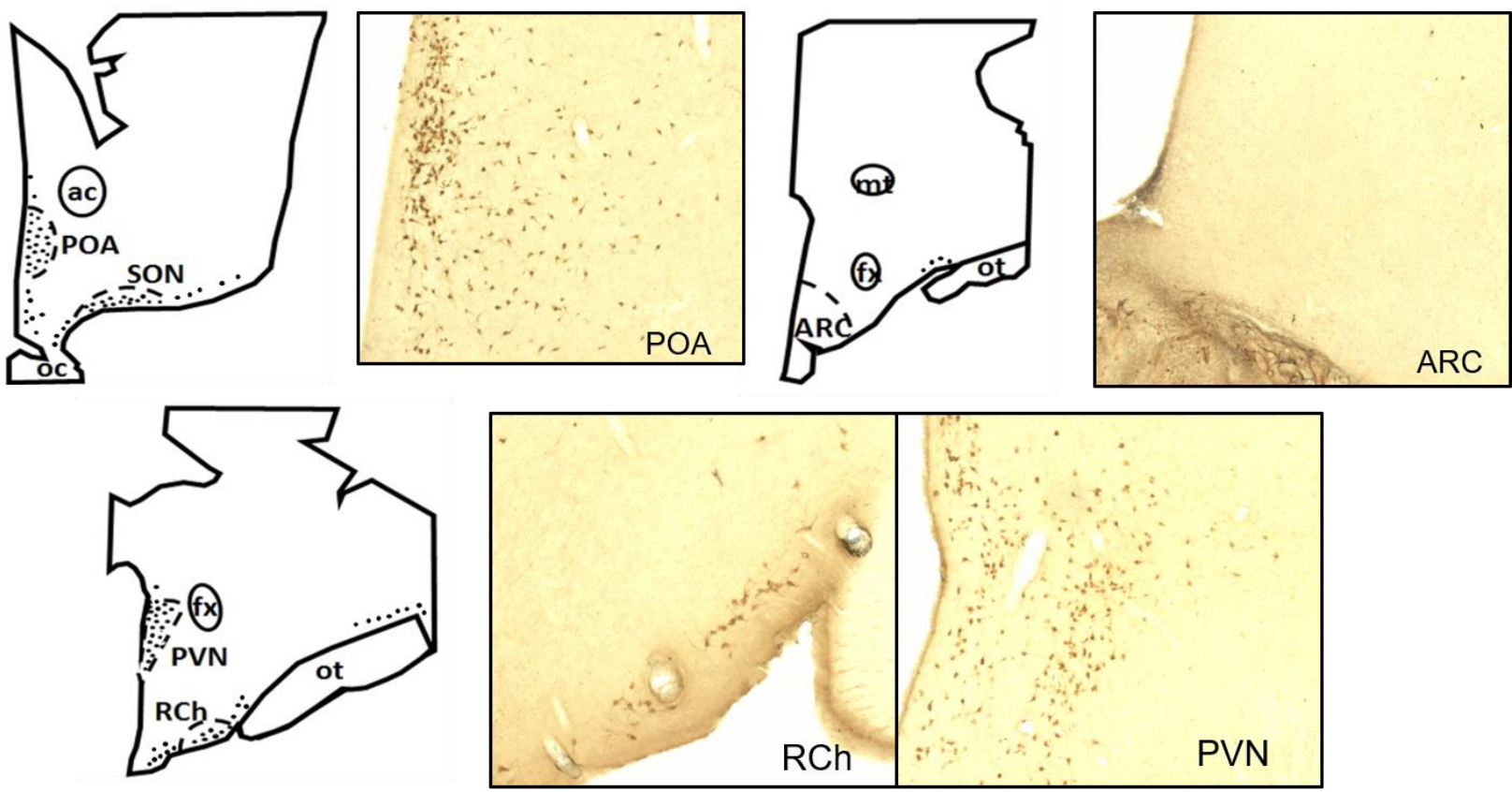

Figure 13: Photomicrographs (20x; right) and schematic drawings (left) of coronal slices through porcine POA and hypothalamus from OVX gilts representing the distribution of NK3R-containing neurons (solid circles). Note the lack of detectable staining within the ARC. ac, anterior commissure; ARC, arcuate nucleus; DBB, diagonal band of Broca; fx, fornix; mt, mammillothalamic tract; oc, optic chiasm; ot, optic tract; PVN, paraventricular nucleus; RCh, retrochiasmatic area; SON, supraoptic nucleus.

\section{Discussion}

Pork is the most consumed meat worldwide and the pork industry is rapidly growing in developing countries [37]. This growth is due to the fact that swine breeds are adaptable to many climates and can be used as a major food source in different environments [275]. The efficiency of a breeding herd is directly correlated to the number of litters and litter size produced by the sow each year [45]. Thus, timely achievement of puberty and appropriate estrous expression in gilts is a major factor affecting sow productivity and overall pork production. In addition to their importance to agriculture, pigs are very similar to humans anatomically and physiologically and 
have been used as biological model for studying a myriad of diseases and processes for decades [276].

This work focused on the role of KNDy neurons in regulating reproduction in the pig. The KNDy system has been relatively well-studied in several species, including sheep [19,271], primates [23], heifers [34] and rodents [31]. However, information in the pig has been exceedingly sparse, despite the abovementioned economic importance of this species to agriculture. Basic neuroanatomical characterization of the KNDy system has not been performed, and the influence of ovarian steroids, such as progesterone, on these neurons in the pig has yet to be examined. Herein we describe that kisspeptin and NKB are coexpressed within the ARC of the postpubertal gilt and expression of either is not suppressed by treatment with the progestin, Altrenogest. Despite the failure of Altrenogest to reduce kisspeptin-immunopositive cell numbers, the activity of kisspeptin neurons tended to be decreased in OVXA gilts. We further describe a distribution of NK3R that is similar to other species, with the important exception that no neurons immunopositive for NK3R were found within the ARC. Similar to kisspeptin and NKB, NK3R populations in the POA and various hypothalamic areas examined were not suppressed by the presence of Altrenogest. Comparable to other species, GnRH neurons did not express NK3R, although $41 \%$ of GnRH neurons expressed at least one NK3Rpositive contact. In general, the KNDy system in pigs is largely similar to that described in most other species. This raises the likely possibility that KNDy neurons play an integral role in regulating reproduction in swine.

Both kisspeptin and NKB were expressed in the ARC of postpubertal gilts. While this is not surprising, the distribution of kisspeptin differed somewhat from what we have previously observed in sheep [26]. In the pig, kisspeptin-containing neurons were located more in the 
medial to dorsal portion of the ARC and were not normally found in the more ventral region of the nucleus or toward the stalk ME. Nonetheless, as has been described for other species $[17,19,31,271]$, kisspeptin and NKB were highly coexpressed. It remains to be determined whether these neurons also coexpress the third peptide of the KNDy triad, dynorphin. Our attempts to uncover dynorphin immunopositive cells in the ARC of these same gilts to date have not been successful, although staining is evident in other areas such as the SON and PVN (data not shown). This may not be too surprising as we also failed to find dynorphin staining in the ARC of young (i.e. prepubertal) female sheep [86]. There are several potential explanations for this lack of dynorphin immunoreactivity, but it is possible that immunocytochemistry may not be the ideal technique to detect very low levels of protein expression. A different approach, such as in situ hybridization or RNAScope, may be necessary to definitively answer the question of whether kisspeptin and NKB neurons of the porcine ARC are truly KNDy neurons.

Ovarian steroids exert both positive (estrogen) and negative (estrogen and progesterone) feedback to regulate GnRH release through actions at the level of the hypothalamus and the response to $\mathrm{GnRH}$ at the anterior pituitary. Secretion of $\mathrm{GnRH}$ and $\mathrm{LH}$ are suppressed when OVX animals are treated with estrogen $[8,18,35,117,277]$ and this suppression is associated with decreased expression of kisspeptin and NKB mRNA and peptide concentrations within the ARC [26,82,277]. Although the influence of estrogen on expression of kisspeptin and NKB has been well-documented, the influence of progesterone has received relatively little attention. Progesterone disrupts gonadotropin secretion by inhibiting the frequency of pulsatile GnRH release, but does not do so directly as GnRH neurons do not express progesterone receptor (PR) [278]. Therefore, upstream neuronal networks that express PR must mediate the influence of progesterone on GnRH secretion. Most KNDy neurons (>95\%) in the ARC of sheep co-express 
PR [271] and may, therefore, mediate progesterone's inhibition of GnRH secretion. In primates, progesterone has been shown to decrease kisspeptin mRNA expression in the MBH [279]. Although there was an inhibitory influence of luteal phase progesterone concentrations on kisspeptin mRNA levels in that study [279], there was no significant effect on mean LH and frequency of LH pulses was not assessed. Similarly, without the presence of or priming with estrogen, progesterone has been shown to have no effect on LH secretion in rats [280] and insignificant negative feedback on LH and GnRH secretion in ewes [281]. Expression of kiss-1 mRNA in OVX sheep treated with progesterone was only partially restored to levels observed in gonad-intact animals [282] and progesterone was not as effective as estrogen. In the current study, a progestin, Altrenogest, was used to examine the potential effect of progesterone on expression of kisspeptin in the hypothalamus of the gilt. It was found that Altrenogest did not suppress the number of kisspeptin nor NKB immunopositive cells in the ARC of postpubertal gilts. Indeed, there was a tendency for a statistically significant increase (kisspeptin) or numerical increase $(\mathrm{NKB})$ in cell numbers. This was surprising because Altrenogest clearly inhibited LH pulse frequency in these pigs and progesterone is a known inhibitor of LH secretion in the gilt [283].

One possible explanation for the finding of increased kisspeptin or NKB cell numbers after Altrenogest treatment is that progesterone inhibited kisspeptin protein release more preferentially than synthesis; therefore, causing denser staining due to higher concentrations of kisspeptin within the cells and allowing for the detection of more cells. To address this possibility, c-Fos expression in kisspeptin cells was quantified. Consistent with a greater effect on secretion than synthesis, a trend for a decreased percentage of kisspeptin cells expressing cFos in the ARC of Altrenogest-treated gilts was observed. Reduced expression of c-Fos is 
indicative of reduced activation of kisspeptin neurons in OVXA gilts. However, it should be noted that similar numbers of Fos-positive cells were observed in both treatment groups while the total numbers of kisspeptin cells differed between them. Because kisspeptin cell numbers tended to be greater in the Altrenogest treated gilts, the decreased percentage of activation in that group could simply be a by-product of those increased kisspeptin cell numbers. Another possibility, which is not mutually exclusive, is that Altrenogest may act to indirectly alter secretion of kisspeptin. Evidence suggests that the endogenous opioid peptide, dynorphin, mediates progesterone negative feedback in ewes $[266,267]$ and mice [31]. Since dynorphin and kisspeptin are coexpressed in KNDy neurons throughout the ARC in other species, stimulation of dynorphin release could inhibit kisspeptin secretion from these neurons and suppress LH secretion [202]. However, a previous study using gilts OVX before puberty indicated that progesterone's negative feedback on LH may not be mediated by endogenous opioid peptides but is more correlated with brain maturation [284]. Therefore, the presence of a progestin such as Altrenogest may not act through systems other than the KNDy population. An additional factor to consider is the endocrine status of the experimental gilts. Although they were ovariectomized to isolate the potential actions of progesterone, normal physiology of this system involves the interactions of both estrogen and progesterone. Hypothalamic expression of PR is frequently regulated by estrogen through estrogen response elements within the progesterone receptor gene [285-287]. Estrogen action is required to stimulate progesterone receptor RNA synthesis, protein production and responsiveness to progesterone [288]. An estrogen priming period is necessary for sustained progesterone action in OVX sheep or progesterone negative feedback will be absent [289]. Therefore, the lack of estrogen in OVX gilts could preclude a significant effect of progesterone on kisspeptin and other cell populations analyzed in this study. Whether there may 
be a species-specific difference in the influence of estrogen on PR expression in swine versus other species such as sheep [282] or primates [279] is not known.

Distribution of NK3R throughout the POA and hypothalamus was relatively similar to that previously described for other species [22,23,231,233,238,239]. Regarding areas that are important for reproduction, expression was prevalent in the POA and PVN with a smaller population in the RCh. Previous work in adult sheep showed that administration of the NK3R agonist, senktide, into the POA or RCh results in a robust increase in LH secretion [106,246]. We found no evidence that GnRH neurons within the POA expressed NK3R. This finding is consistent with previous work in ewes [243,244], and rats [22]. In the gilts of our study, we found that $41 \%$ of POA GnRH neurons were apposed by NK3R-positive varicosities, which is similar to a recent study in ewes that showed $>70 \%$ of GnRH cells in the POA exhibit presynaptic close contacts with fibers containing NK3R [243]. This indicates that NKB may act presynaptically in close vicinity to GnRH neurons of the pig to alter their activity.

The lack of NK3R expression in GnRH neurons suggests that in the pig, much like other species, NKB likely does not influence GnRH secretion directly. Instead, it has been suggested that NKB acts on KNDy neurons in a reciprocal fashion within the ARC to stimulate kisspeptin release and thus initiate an LH pulse [22]. This, of course, is predicated on NK3R expression in KNDy neurons of the ARC. Up to $60 \%$ of KNDy neurons and NKB-containing cells in the ARC contain NK3R in sheep and rodents $[22,31,244]$. NKB is a potent stimulator of GnRH secretion in sheep [25], goats [17], monkeys [23] and rats in the presence of physiological levels of $\mathrm{E}_{2}$ [22]. Our previous work showed that microimplantation of senktide within the ARC elicits LH secretion in adult ewes [246]. However, in the current study, we did not find NK3R immunoreactivity in the ARC of gilts. This was surprising, but it was consistently absent even 
when we employed approaches such as antigen retrieval or tyramide amplification. NK3Rcontaining cells were easily identified in other areas of the hypothalamus in tissue sections run concurrently with ARC sections, so we do not believe it to be an issue with the technique. We have recently observed in preliminary work with prepubertal sheep that NK3R immunoreactivity is much more punctate and sparse in the ARC than other regions of the hypothalamus, making cells difficult to identify. However, even this type of staining was absent in gilts. Further work will be necessary, perhaps using other approaches such as in situ hybridization, to determine if NK3R is in fact not expressed in the ARC of the pig.

This is the first study to analyze the effect of progesterone alone on NK3R expression. Altrenogest did not alter NK3R cell counts in the PVN, RCh or POA. Work to date clearly shows that NKB expression is sensitive to steroid negative feedback [243]. NKB gene expression [233] or protein expression [26] increases after ovariectomy and NKB, along with its receptor, decreases during the significant increase in estradiol that occurs during the LH surge [22]. Again, this experiment studied the effect of progesterone alone. It may be that estrogen is required for progesterone to fully influence NK3R expression as previously stated in the cases of kisspeptin and NKB. Alternatively, changes in receptor expression may not be as important in mediating progesterone feedback as the decreased release of NKB and kisspeptin. These data regarding the trend for decreased activation of kisspeptin neurons in the presence of Altrenogest would support such a supposition.

In summary, the neuroanatomy of kisspeptin, NKB and NK3R protein expression in pigs was largely similar to what has been reported for other species. Kisspeptin and NKB co-localized at high percentages in the ARC and NK3R-expressing neurons were found in the POA and throughout the hypothalamus. Also, as has been shown in other species, NK3R did not co- 
localize with GnRH neurons in the POA, but a subpopulation of GnRH neurons was contacted by NK3R-containing varicosities. Compared to previous research in other species, the main differences observed in this study lie with the lack of NK3R in the ARC and a failure of Altrenogest to affect kisspeptin cell numbers despite a reduction in LH pulse frequency. However, Altrenogest tended to reduce the activation of kisspeptin neurons, potentially providing a mechanism underlying the observed reduction in LH pulse frequency. It is suggested that these data support the idea that the KNDy system is largely comparable between swine and other species and likely plays an integral role in regulating reproduction in pigs. 


\section{BIBLIOGRAPHY}

[1] Navarro VM, Castellano JM, García-Galiano D, Tena-Sempere M. Neuroendocrine factors in the initiation of puberty: The emergent role of kisspeptin. Rev Endocr Metab Disord 2007; 8:11-20.

[2] Plant TM. The hypothalamo-pituitary-gonadal axis. J Endocrinol 2015; 226: T41-T54.

[3] Foster DL, Ryan KD. Endocrine mechanisms governing transition into adulthood: A marked decrease in inhibitory feedback action of estradiol on tonic secretion of luteinizing hormone in the lamb during puberty. Endocrinology 1979; 105:896-904.

[4] Hohlweg W, Chamorro A. Über die Luteinisierende Wirkung des Follikelhormons Durch Beeinflussung der Luteogenen Hypophysenvorder-Lappensekretion. Klin Wochenschr $1937 ; 16: 196-197$.

[5] Noguchi M, Yoshioka K, Itoh S, Suzuki C, Arai S, Wada Y, Hasegawa Y, Kaneko H. Peripheral concentrations of inhibin A, ovarian steroids, and gonadotropins associated with follicular development throughout the estrous cycle of the sow. Reproduction 2010; 139:153-161.

[6] Soede NM, Langendijk P, Kemp B. Reproductive cycles in pigs. Anim Reprod Sci 2011; 124:251-258.

[7] Esbenshade KL, Ziecik A., Britt JH. Regulation and action of gonadotropins in pigs. Journals Reprod Fertil 1990; 40:19-32.

[8] Dorling AA, Todman MG, Korach KS, Herbison AE. Critical role for estrogen receptor alpha in negative feedback regulation of gonadotropin-releasing hormone mRNA expression in the female mouse. Neuroendocrinology 2003; 78:204-209.

[9] Franceschini I, Lomet D, Cateau M, Delsol G, Tillet Y, Caraty A. Kisspeptin 
immunoreactive cells of the ovine preoptic area and arcuate nucleus co-express estrogen receptor alpha. Neurosci Lett 2006; 401:225-230.

[10] Lehman MN, Elbing FJP, Moenter SM, Karsch FJ. Distribution of estrogen receptorimmunoreactive cells in the sheep brain. Endocrinology 1993; 133:876-886.

[11] de Roux N, Genin E, Carel J-C, Matsuda F, Chaussain J-L, Milgrom E. Hypogonadotropic hypogonadism due to loss of function of the KiSS1-derived peptide receptor GPR54. Proc Natl Acad Sci 2003; 100:10972-10976.

[12] Seminara SB, Messager S, Chatzidaki EE, Thresher RR, Acierno JS, Shagoury JK, BoAbbas Y, Kuohung W, Schwinof KM, Hendrick AG, Zahn D, Dixon J, et al. The GPR54 gene as a regulator of puberty. Obstet Gynecol Surv 2003; 59:351-353.

[13] Gottsch ML, Cunningham MJ, Smith JT, Popa SM, Acohido B V., Crowley WF, Seminara S, Clifton DK, Steiner RA. A role for kisspeptins in the regulation of gonadotropin secretion in the mouse. Endocrinology 2004; 145:4073-4077.

[14] Lents CA, Heidorn NL, Barb CR, Ford JJ. Central and peripheral administration of kisspeptin activates gonadotropin but not somatotropin secretion in prepubertal gilts. Reproduction 2008; 135:879-887.

[15] Dhillo WS, Chaudhri OB, Patterson M, Thompson EL, Murphy KG, Badman MK, McGowan BM, Amber V, Patel S, Ghatei MA, Bloom SR. Kisspeptin-54 stimulates the hypothalamic-pituitary gonadal axis in human males. J Clin Endocrinol Metab 2005; 90:6609-6615.

[16] Plant TM, Ramaswamy S, DiPietro MJ. Repetitive activation of hypothalamic G proteincoupled receptor 54 with intravenous pulses of kisspeptin in the juvenile monkey (Macaca mulatta) elicits a sustained train of gonadotropin-releasing hormone discharges. 
Endocrinology 2006; 147:1007-1013.

[17] Wakabayashi Y, Nakada T, Murata K, Ohkura S, Mogi K, Navarro VM, Clifton DK, Mori Y, Tsukamura H, Maeda K-I, Steiner RA, Okamura H. Neurokinin B and Dynorphin A in Kisspeptin neurons of the arcuate nucleus participate in generation of periodic oscillation of neural activity driving pulsatile gonadotropin-releasing hormone secretion in the goat. J Neurosci 2010; 30:3124-3132.

[18] Goodman RL, Lehman MN. Kisspeptin neurons from mice to men: similarities and differences. Endocrinology 2012; 153:5105-5118.

[19] Goodman RL, Lehman MN, Smith JT, Coolen LM, De Oliveira CVR, Jafarzadehshirazi MR, Pereira A, Iqbal J, Caraty A, Ciofi P, Clarke IJ. Kisspeptin neurons in the arcuate nucleus of the ewe express both dynorphin A and neurokinin B. Endocrinology 2007; 148:5752-5760.

[20] Topaloglu AK, Reimann F, Guclu M, Yalin AS, Kotan LD, Porter KM, Serin A, Mungan NO, Cook JR, Ozbek MN, Imamoglu S, Akalin NS, et al. TAC3 and TACR3 mutations in familial hypogonadotropic hypogonadism reveal a key role for Neurokinin B in the central control of reproduction. Nat Genet 2009; 41:354-8.

[21] Guran T, Tolhurst G, Bereket A, Rocha N, Porter K, Turan S, Gribble FM, Kotan LD, Akcay T, Atay Z, Canan H, Serin A, et al. Hypogonadotropic hypogonadism due to a novel missense mutation in the first extracellular loop of the neurokinin B receptor. J Clin Endocrinol Metab 2009; 94:3633-9.

[22] Navarro VM, Castellano JM, McConkey SM, Pineda R, Ruiz-Pino F, Pinilla L, Clifton DK, Tena-Sempere M, Steiner RA. Interactions between kisspeptin and neurokinin B in the control of GnRH secretion in the female rat. Am J Physiol Endocrinol Metab 2011; 
300: E202-E210.

[23] Ramaswamy S, Seminara SB, Ali B, Ciofi P, Amin NA, Plant TM. Neurokinin B stimulates GnRH release in the male monkey (Macaca mulatta) and is colocalized with kisspeptin in the arcuate nucleus. Endocrinology 2010; 151:4494-4503.

[24] Messager S, Chatzidaki EE, Ma D, Hendrick AG, Zahn D, Dixon J, Thresher RR, Malinge I, Lomet D, Carlton MBL, Colledge WH, Caraty A, et al. Kisspeptin directly stimulates gonadotropin-releasing hormone release via G protein-coupled receptor 54. Proc Natl Acad Sci 2005; 102:1761-1766.

[25] Billings HJ, Connors JM, Altman SN, Hileman SM, Holaskova I, Lehman MN, McManus CJ, Nestor CC, Jacobs BH, Goodman RL. Neurokinin B acts via the neurokinin-3 receptor in the retrochiasmatic area to stimulate luteinizing hormone secretion in sheep. Endocrinology 2010; 151:3836-3846.

[26] Nestor CC, Briscoe AMS, Davis SM, Valent M, Goodman RL, Hileman SM. Evidence of a role for kisspeptin and neurokinin B in puberty of female sheep. Endocrinology 2012; 153:2756-2765.

[27] García-Galiano D, Van Ingen Schenau D, Leon S, Krajnc-Franken MAM, ManfrediLozano M, Romero-Ruiz A, Navarro VM, Gaytan F, Van Noort PI, Pinilla L, Blomenröhr M, Tena-Sempere M. Kisspeptin signaling is indispensable for neurokinin B, but not glutamate, stimulation of gonadotropin secretion in mice. Endocrinology 2012; 153:316328.

[28] Ramaswamy S, Seminara SB, Plant TM. Evidence from the agonadal juvenile male rhesus monkey (macaca mulatta) for the view that the action of neurokinin $b$ to trigger gonadotropin-releasing hormone release is upstream from the kisspeptin receptor. 
Neuroendocrinology 2011; 94:237-245.

[29] Lehman MN, Merkley CM, Coolen LM, Goodman RL. Anatomy of the kisspeptin neural network in mammals. Brain Res 2010; 1364:90-102.

[30] Maeda KI, Ohkura S, Uenoyama Y, Wakabayashi Y, Oka Y, Tsukamura H, Okamura H. Neurobiological mechanisms underlying GnRH pulse generation by the hypothalamus. Brain Res 2010; 1364:103-115.

[31] Navarro VM, Gottsch ML, Chavkin C, Okamura H, Clifton DK, Steiner RA. Regulation of Gonadotropin-Releasing Hormone Secretion by Kisspeptin/Dynorphin/Neurokinin B Neurons in the Arcuate Nucleus of the Mouse. J Neurosci 2009; 29:11859-11866.

[32] Lehman MN, Hileman SM, Goodman RL. Chapter 3: Neuroanatomy of the Kisspeptin Signaling System in Mammals: Comparative and Developmental Aspects. Kisspeptin Signaling in Reproductive Biology, vol. 784. 2013:27-62.

[33] Burke MC, Letts PA, Krajewski SJ, Range NE. Coexpression of dynorphin and neurokinin B immunoreactivity in the rat hypothalamus: Morphologic evidence of interrelated function within the arcuate nucleus. J Comp Neurol 2006; 498:712-726.

[34] Hassaneen ASA, Naniwa Y, Suetomi Y, Matsuyama S, Kimura K, Ieda N, Inoue N, Uenoyama Y, Tsukamura H, Maeda K, Matsuda F, Ohkura S. Immunohistochemical characterization of the arcuate kisspeptin/neurokinin B/dynorphin (KNDy) and preoptic kisspeptin neuronal populations in the hypothalamus during the estrous cycle in heifers. J Reprod Dev 2016; 62:471-477.

[35] Plant TM. A comparison of the neuroendocrine mechanisms underlying the initiation of the preovulatory LH surge in the human, Old World monkey and rodent. Front Neuroendocrinol 2012; 33:160-168. 
[36] Taylor RE, Robert E, Field TG, Thomas G. Scientific farm animal production: an introduction to animal science. 6th ed. Upper Saddle River, N.J.: Prentice Hall; 1998.

[37] Gonzalez-Bulnes A, Astiz S, Ovilo C, Lopez-Bote CJ, Torres-Rovira L, Barbero A, Ayuso M, Garcia-Contreras C, Vazquez-Gomez M. Developmental origins of health and disease in swine: implications for animal production and biomedical research. Theriogenology 2016; 86:110-119.

[38] Ruvinsky A, Rothschild MF. Systematics and evolution of the pig. The genetics of the pig. Wallingford: Cab International; 1998:1-16.

[39] Britt JH. Improving sow productivity through management during gestation, lactation and after weaning. J Anim Sci 1986; 63:1288-1296.

[40] Lutz JB, Rampacek GB, Kraeling RR, Pinkert CA. Serum luteinizing hormone and estrogen profiles before puberty in the gilt. J Anim Sci 1984; 58:19-19.

[41] Stancic I, Stancic B, Bozic A, Anderson R, Harvey R, Gvozdic D. Ovarian activity and uterus organometry in delayed puberty gilts. Theriogenology 2011; 76:1022-1026.

[42] Amaral Filha WS, Bernardi ML, Wentz I, Bortolozzo FP. Growth rate and age at boar exposure as factors influencing gilt puberty. Livest Sci 2009; 120:51-57.

[43] Kuehn LA, Nonneman DJ, Klindt JM, Wise TH. Genetic relationships of body composition, serum leptin, and age at puberty in gilts. J Anim Sci 2009; 87:477-483.

[44] Kraeling RR, Webel SK. Current strategies for reproductive management of gilts and sows in North America. J Anim Sci Biotechnol 2015; 6:1-14.

[45] Hughes PE, Varley MA. Reproduction in the pig. London: Butterworth \& Co. (Publishers) Ltd.; 1980.

[46] Harris GW. Neural control of the pituitary gland. Physiol Rev 1948; 28:139-179. 
[47] Schally AV, Arimura A, Baba Y, Nair RMG, Matsuo H, Redding TW, Debeljuk L, White WF. Isolation and properties of the FSH and LH-releasing hormone. Biochem Biophys Res Commun 1971; 43:393-399.

[48] Herbison AE. Physiology of the adult gonadotropin-releasing hormone neuronal network. In: Plant TM, Zeleznik A (eds.), Knobil and Neill's Physiology of Reproduction. 4th ed. Elsevier, Amsterdam; 2015:399-467.

[49] Herbison AE. Control of puberty onset and fertility by gonadotropin-releasing hormone neurons. Nat Rev Endocrinol 2016; 12:452-466.

[50] Schwanzel-Fukada M, Pfaff D. Origin of luteinizing hormone-releasing hormone neurons. Nature 1989; 338:161-164.

[51] Schwanzel-Fukuda M, Pfaff DW. The migration of luteinizing hormone-releasing hormone (LHRH) neurons from the medial olfactory placode into the medial basal forebrain. Experientia 1990; 46:956-62.

[52] Wray S. From nose to brain: development of gonadotrophin-releasing hormone-1 neurones. J Neuroendocrinol 2010; 22:743-53.

[53] Herbison AE. Physiology of the gonadotropin-releasing hormone neuronal network. Knobil and Neill's Physiology of Reproduction (Third Edition). Elsevier; 2006:14151482.

[54] Kineman RD, Leshin LS, Crim JW, Rampacek GB, Kraeling RR. Localization of luteinizing hormone-releasing hormone in the forebrain of the pig. Biol Reprod 1988; 39:665-672.

[55] Lehman MN, Robinson JE, Karsch FJ, Silverman A-J. Immunocytochemical localization of luteinizing hormone-releasing hormone (LHRH) pathways in the sheep brain during 
anestrus and the mid-luteal phase of the estrous cycle. J Comp Neurol 1986; 244:19-35.

[56] Witkin JW, Paden CM, Silverman AJ. The luteinizing hormone-releasing hormone (LHRH) systems in the rat brain. Neuroendocrinology 1982; 35:429-438.

[57] Silverman AJ, Antunes JL, Ferin M, Zimmerman EA. The distribution of luteinizing hormone-releasing hormone (LHRH) in the hypothalamus of the rhesus monkey. light microscopic studies using immunoperoxidase technique. Endocrinology 1977; 101:134142.

[58] Goldsmith PC, Thind KK, Song T, Jung E, James EB. Location of the neuroendocrine gonadotropin-releasing hormone neurons in the monkey hypothalamus by retrograde tracing and immunostaining. J Neuroendocrinol 1990; 2:157-168.

[59] Abitua PB, Gainous TB, Kaczmarczyk AN, Winchell CJ, Hudson C, Kamata K, Nakagawa M, Tsuda M, Kusakabe TG, Levine M. The pre-vertebrate origins of neurogenic placodes. Nature 2015; 524:462-465.

[60] Wierman ME, Kiseljak-Vassiliades K, Tobet S. Gonadotropin-releasing hormone (GnRH) neuron migration: Initiation, maintenance and cessation as critical steps to ensure normal reproductive function. Front Neuroendocrinol 2011; 32:43-52.

[61] Herde MK, Iremonger KJ, Constantin S, Herbison AE. GnRH neurons elaborate a longrange projection with shared axonal and dendritic functions. J Neurosci 2013; 33:1268912697.

[62] Seminara SB, Hayes FJ, Crowley WF. Gonadotropin-releasing hormone deficiency in the human (idiopathic hypogonadotropic hypogonadism and kallmann's syndrome):

Pathophysiological and Genetic Considerations. Endocr Rev 1998; 19:521-539.

[63] Teixeira L, Guimiot F, Dodé C, Fallet-Bianco C, Millar RP, Delezoide AL, Hardelin JP. 
Defective migration of neuroendocrine GnRH cells in human arrhinencephalic conditions. J Clin Invest 2010; 120:3668-3672.

[64] Dierschke DJ, Karsh FJ, Weick RF, Weiss G, Hotchkiss J, Knobil E. Hypothalamic pituitary regulation of puberty: feedback control of gonadotropin secretion in the rhesus monkey. Control Onset Puberty Wiley Sons, New York 1974; 104.

[65] Belchetz P, Plant T, Nakai Y, Keogh E, Knobil E. Hypophysial responses to continuous and intermittent delivery of hypopthalamic gonadotropin-releasing hormone. Science $1978 ; 202: 631-633$.

[66] Knobil E, Plant TM, Wildt L, Belchetz P, Marshall G. Control of the rhesus monkey menstrual cycle: Permissive role of hypothalamic Gonadotropin-releasing hormone. Science 1980; 207:1371-3.

[67] Karsch FJ, Bowen JM, Caraty A, Evans NP, Moenter SM. Gonadotropin-releasing hormone requirements for ovulation. Biol Reprod 1997; 56:303-309.

[68] Clarke IJ, Cummins JT. The temporal relationship between gonadotropin releasing hormone $(\mathrm{GnRH})$ and luteinizing hormone $(\mathrm{LH})$ secretion in ovariectomized ewes. Endocrinol - Endocr Soc 1982; 111:1737-1739.

[69] Levine JE, Pau KF, Ramirez VD, Jackson GL. Simultaneous measurement of luteinizing hormone - releasing hormone and luteinizing hormone release in unanesthetized, ovariectomized sheep. Endocrinology 1982; 111:1449-1455.

[70] Leshin LS, Kraeling RR, Barb CR, Rampacek GB. Associated luteinizing hormonereleasing hormone and luteinizing hormone secretion in ovariectomized gilts. Domest Anim Endocrinol 1992; 9:77-88.

[71] Patterson-Bay DJ, Geisert RD, Hill CM, Minton JE, McCann JP, Morgan GL. GnRH 
antagonist inhibition of luteinizing hormone secretion and ovulation in the pig. Anim Reprod Sci 1997; 49:207-214.

[72] Carmel, P; Araki, S; Ferin M. Pituitary Stalk Portal Blood Collection in Rhesus Monkeys: Evidence for pulsatile release of gonadotropin-releasing hormone $(\mathrm{GnRH})$. Endocrinology 1976; 99:243-248.

[73] Senger PL. Pathway to pregnancy and parturition. Current Conceptions, Inc; 2012.

[74] Guthrie HD, Henricks DM, Handlin DL. Plasma estrogen, progesterone and luteinizing hormone prior to estrus and during early pregnancy in pigs. Endocrinology 1972; 91:675679.

[75] Marshall JC, Dalkin AC, Haisenleder DJ, Paul SJ, Ortolano GA, Kelch RP. Gonadotropinreleasing hormone pulses: regulators of gonadotropin synthesis and ovulatory cycles. Int $\mathbf{J}$ Rock Mech Min Sci Geomech Abstr 1991; 47:155-187.

[76] Knobil E. The GnRH pulse generator. Am J Obstet Gynecol 1990; 163:1721-1727.

[77] Kesner JS, Kraeling RR, Rampacek GB, Johnson B. Absence of an estradiol-induced surge of luteinizing hormone in pigs receiving unvarying pulsatile gonadotropin-releasing hormone stimulation 1987; 121:1862-1869.

[78] Kesner JS, Estienne MJ, Kraeling RR, Rampacek GB. Luteinizing hormone and prolactin secretion in hypophysial-stalk-transected pigs given estradiol and pulsatile gonadotropinreleasing hormone. Neuroendocrinology 1989; 49:502-508.

[79] Britt JH, Esbenshade KL, Ziecik AJ. Roles of estradiol and gonadotropin-releasing hormone in controlling negative and positive feedback associated with the luteinizing hormone surge in ovariectomized pigs. Biol Reprod 1991; 45:478-485.

[80] Krsmanovic LZ, Hu L, Leung PK, Feng H, Catt KJ. The hypothalamic GnRH pulse 
generator: multiple regulatory mechanisms. Trends Endocrinol Metab 2009; 20:402-408.

[81] Christian CA, Moenter SM. The neurobiology of preovulatory and estradiol-induced gonadotropin- releasing hormone surges. Endocr Rev 2010; 31:544-577.

[82] Bedenbaugh MN, D'Oliveira M, Cardoso RC, Hileman SM, Williams GL, Amstalden M. Pubertal escape from estradiol negative feedback in ewe lambs is not accounted for by decreased ESR1 mRNA or protein in kisspeptin neurons. Endocrinology 2017; 159:426438.

[83] Cheng G, Coolen LM, Padmanabhan V, Goodman RL, Lehman MN. The Kisspeptin/Neurokinin B/Dynorphin (KNDy) cell population of the arcuate nucleus: sex differences and effects of prenatal testosterone in sheep. Endocrinology 2010; 151:301311.

[84] L. Goodman R, Inskeep K. Control of the ovarian cycle of the sheep. vol. 2. 2015.

[85] Weems PW, Witty CF, Amstalden M, Coolen LM, Goodman RL, Lehman MN. $\kappa$-opioid receptor is colocalized in GnRH and KNDy cells in the female ovine and rat brain. Endocrinology 2016; 157:2367-2379.

[86] Lopez J, Bedenbaugh M, McCosh R, Weems P, Meadows L, Wisman B, Coolen L, Goodman R, Hileman S. Does dynorphin play a role in the onset of puberty in female sheep? J Neuroendocrinol 2016; 28.

[87] O'byrne KT, Thalabard JC, Grosser PM, Wilson RC, Williams CL, Chen MD, Ladendorf D, Hotchkiss J, Knobil E. Radiotelemetric monitoring of hypothalamic gonadotropinreleasing hormone pulse generator activity throughout the menstrual cycle of the rhesus monkey. Endocrinology 1991; 129:1207-1214.

[88] Richards JS, Liu Z, Shimada M, Liu Z, Shimada M. Ovulation. Knobil and Neill's 
Physiology of Reproduction. Elsevier; 2015:997-1021.

[89] Moenter SM, Caraty A, Karsch FJ. The estradiol-induced surge of gonadotropin-releasing hormone in the Ewe. Endocrinology 1990; 127:1375-1384.

[90] Goding JR, Catt KJ, Brown JM, Kaltenbach CC, Cumming IA, Mole BJ.

Radioimmunoassay for ovine luteinizing hormone. Secretion of luteinizing hormone during estrus and following estrogen administration in sheep. Endocrinology 1969; 85:133-142.

[91] Everett JW, Sawyer CH. A 24-hour periodicity in the 'LH-release apparatus' of female rats, disclosed by barbiturate sedation. Endocrinology 1950; 47:198-218.

[92] Halasz B, Gorski RA. Growth hormone secretion in young rats after partial or total interruption of neural afferents to the medial basal hypothalamus. Endocrinology 1971; 89:198-203.

[93] Goodman RL. The site of the positive feedback action of estradiol in the rat. Endocrinology 1978; 102:151-159.

[94] Oakley AE, Clifton DK, Steiner RA. Kisspeptin signaling in the brain. Endocr Rev 2009; 30:713-743.

[95] Wang HJ, Hoffman GE, Smith MS. Increased GnRH mRNA in the GnRH Neurons Expressing cFos During the Proestrous LH Surge. Endocrinology 1995; 136:3673-3676.

[96] Kawakami M, Arita J, Yoshioka E. Loss of estrogen-induced daily surges of prolactin and gonadotropins by suprachiasmatic nucleus lesions in ovariectomized rats. Endocrinology $1980 ; 106: 1087-1092$.

[97] van der Beek EM, Swarts HJ, Wiegant VM. Central administration of antiserum to vasoactive intestinal peptide delays and reduces luteinizing hormone and prolactin surges 
in ovariectomized, estrogen-treated rats. Neuroendocrinology 1999; 69:227-237.

[98] Vida B, Deli L, Hrabovszky E, Kalamatianos T, Caraty A, Coen CW, Liposits Z, Kalló I. Evidence for suprachiasmatic vasopressin neurones innervating kisspeptin neurones in the rostral periventricular area of the mouse brain: Regulation by oestrogen. J Neuroendocrinol 2010; 22:1032-1039.

[99] Cheong RY, Czieselsky K, Porteous R, Herbison AE. Expression of ESR1 in Glutamatergic and GABAergic Neurons Is Essential for Normal Puberty Onset, Estrogen Feedback, and Fertility in Female Mice. J Neurosci 2015; 35:14533-14543.

[100] Evans NP, Dahl E, Caraty A, Padmanabhan V, Thrun LA, Karsch J. How much of the gonadotropin-releasing hormone $(\mathrm{GnRH})$ surge is required for generation of the luteinizing hormone surge in the ewe? Duration of the endogenous GnRH signal. 1996; $137: 4730-4737$.

[101] Caraty A, Fabre-Nys C, Delaleu B, Locatelli A, Bruneau G, Karsch FJ, Herbison a E. Evidence that the mediobasal hypothalamus is the primary site of action of estradiol in inducing the preovulatory gonadotropin releasing hormone surge in the ewe. Endocrinology 1998; 139:1752-1760.

[102] Caraty A, Smith JT, Lomet D, Ben Saïd S, Morrissey A, Cognie J, Doughton B, Baril G, Briant C, Clarke IJ. Kisspeptin synchronizes preovulatory surges in cyclical ewes and causes ovulation in seasonally acyclic ewes. Endocrinology 2007; 148:5258-5267.

[103] Sébert ME, Lomet D, Saïd S Ben, Monget P, Briant C, Scaramuzzi RJ, Caraty A. Insights into the mechanism by which kisspeptin stimulates a preovulatory LH surge and ovulation in seasonally acyclic ewes: Potential role of estradiol. Domest Anim Endocrinol 2010; 38:289-298. 
[104] Smith JT, Li Q, Yap KS, Shahab M, Roseweir AK, Millar RP, Clarke IJ. Kisspeptin is essential for the full preovulatory LH surge and stimulates GnRH release from the isolated ovine median eminence. Endocrinology 2011; 152:1001-1012.

[105] Smith JT. Sex steroid control of hypothalamic Kiss1 expression in sheep and rodents: Comparative aspects. Peptides 2009; 30:94-102.

[106] Merkley CM, Porter KL, Coolen LM, Hileman SM, Billings HJ, Drews S, Goodman RL, Lehman MN. KNDy (kisspeptin/neurokinin B/dynorphin) neurons are activated during both pulsatile and surge secretion of LH in the ewe. Endocrinology 2012; 153:5406-5414.

[107] Hoffman GE, Le WW, Franceschini I, Caraty A, Advis JP. Expression of fos and in Vivo median eminence release of LHRH identifies an active role for preoptic area kisspeptin neurons in synchronized surges of LH and LHRH in the ewe. Endocrinology 2011; 152:214-222.

[108] Estrada KM, Clay CM, Pompolo S, Smith JT, Clarke IJ. Elevated KiSS-1 expression in the arcuate nucleus prior to the cyclic preovulatory gonadotrophin-releasing hormone/lutenising hormone surge in the ewe suggests a stimulatory role for kisspeptin in oestrogen-positive feedback. J Neuroendocrinol 2006; 18:806-809.

[109] Merkley CM, Coolen LM, Goodman RL, Lehman MN. Evidence for changes in numbers of synaptic inputs onto KNDy and GnRH neurones during the Preovulatory LH Surge in the ewe. J Neuroendocrinol 2015; 27:624-635.

[110] Krey LC, Lu KH, Butler WR, Hotchkiss J, Piva F, Knobil E. Surgical disconnection of the medial basal hypothalamus and pituitary function in the rhesus monkey. II. GH and cortisol secretion. Endocrinology 1975; 96:1088-1093.

[111] Ferin M, Rosenblatt H, Carmel PW, Antunes JL, Wiele RLV. Estrogen-induced 
gonadotropin surges in female rhesus monkeys after pituitary stalk section. Endocrinology $1979 ; 104: 50-52$.

[112] Crowley WF, McArthur JW. Simulation of the normal menstrual cycle in kallman's syndrome by pulsatile administration of luteinizing hormone-releasing hormone (LHRH) $1980 ; 51: 173-175$.

[113] Ottowitz WE, Dougherty DD, Fischman AJ, Hall JE. [18F]2-fluoro-2-deoxy-D-glucose positron emission tomography demonstration of estrogen negative and positive feedback on luteinizing hormone secretion in women. J Clin Endocrinol Metab 2008; 93:32083214.

[114] Xia L, Vanvugt D, Alston EJ, Luckhaus J, Ferin M. A surge of gonadotropin-releasing hormone accompanies the estradiol-induced gonadotropin surge in the rhesus monkey. Endocrinology 1992; 131:2812-2820.

[115] Smith JT, Shahab M, Pereira A, Pau K-YF, Clarke IJ. Hypothalamic expression of KISS1 and gonadotropin inhibitory hormone genes during the menstrual cycle of a non-human primate. Biol Reprod 2010; 83:568-577.

[116] Cox NM, Britt JH. Effect of estradiol on hypothalamic GnRH and pituitary and serum LH and FSH in ovariectomized pigs. J Anim Sci 1982; 55:901-908.

[117] Berardinelli JG, Ford JJ, Christenson RK, Anderson LL. Luteinizing hormone secretion in ovariectomized gilts: effects of age, reproductive state and estrogen replacement. J Anim Sci $1984 ; 58: 165-173$.

[118] Suzuki S, Kadokawa H, Hashizume T. Direct kisspeptin-10 stimulation on luteinizing hormone secretion from bovine and porcine anterior pituitary cells. Anim Reprod Sci $2008 ; 103: 360-365$. 
[119] Britt JH, Esbenshade KL, Ziecik A. Site of action of estradiol for eliciting negative and positive feedback responses of LH in pigs. Biol Reprod 1987; 36:114.

[120] Elsaesser F, Parvizi N. Estrogen and the Feedback Effect in the Pig: sexual differentiation treatment of prenatal testosterone. Biol Reprod 1979; 20:1187-1193.

[121] Elsaesser F, Foxcroft GR. Maturational changes in the characteristics of oestrogeninduced surges of luteinizing hormone in immature domestic gilts. J Endocrinol 1978; $78: 455-6$.

[122] Reeves J, Arimura A, Schally AV. Changes in pituitary releasing responsiveness with estradiol to luteinizing in anestrous hormone-ewes hormone pretreated with estradiol benzoate. Biol Reprod 1970; 4:88-92.

[123] Esbenshade KL, Paterson AM, Cantley TC, Day BN. Changes in plasma hormone concentrations associated with the onset of puberty in the gilt. J Anim Sci 1982; 54:320324.

[124] Levasseur M. Thoughts on puberty. Initiation of the gonadotropic function. Ann Biol Biochim Biophys 1977; 17:345-361.

[125] Rozeboom DW, Pettigrew JE, Moser RL, Cornelius SG, Kandelgy SM, Mosel RL, El SM. Body composition of gilts at puberty. J Anim Sci 1995:2524-2531.

[126] Nelson AH, Mabry JW, Benyshek LL, Marks MA. Correlated response in reproduction, growth and composition to selection in gilts for extremes in age at puberty and backfat. Livest Prod Sci 1990; 24:237-247.

[127] Ramirez VD, Mccann SM. Comparison of the regulation of luteinizing hormone (LH) secretion in immature and adult rats. Endocrinology 1963; 72:452-464.

[128] Grumbach MM, Grave GD, Mayer FE, National Institute of Child Health and Human 
Development (U.S.). Growth and Development Branch. Control of the onset of puberty. New York: Wiley; 1974.

[129] Liefer RW, Foster DL, Dziuk PJ. Levels of LH in the sera and pituitaries of female lambs following ovariectomy and administration of estrogen. Endocrinology 1972; 90:981-985.

[130] Foster DL, Nagatani S. Physiological perspectives on leptin as a regulator of reproduction: role in timing puberty. Biol Reprod 1999; 60:205-215.

[131] Cunningham PJ, Naber CH, Zimmerman DR, Peo ER. Influence of nutritional regime on age at puberty in gilts. J Anim Sci 1974; 39:63-67.

[132] Kennedy BYGC, Mitra J. Body weight and food intake as initiating factors for puberty in the rat. J Physiol 1963; 166:408-418.

[133] Kirkwood RN, Aherne FX. Energy intake, body composition and reproductive performance of the gilt. J Anim Sci 1985; 60:1518-1529.

[134] Barb CR, Robertson AS, Barrett JB, Kraeling RR, Houseknecht KL. The role of melanocortin-3 and -4 receptor in regulating appetite, energy homeostasis and neuroendocrine function in the pig. J Endocrinol 2004; 181:39-52.

[135] Frisch RE. Fatness and fertility. Sci Am 1988; 258:88-95.

[136] Hileman SM, Tornøe J, Flier JS, Bjørbæk C. Transcellular transport of leptin by the short leptin receptor isoform ObRa in Madin-Darby canine kidney cells. Endocrinology 2000; 141:1955-1961.

[137] Ershoff BH. Nutrition and the anterior pituitary with special reference to the general adaptation syndrome. Vitam Horm 1952; 10:79-140.

[138] Frisch RE. Body fat, puberty and fertility. Biol Rev 1984; 59:161-188.

[139] Frisch RE. The right weight: body fat, menarche and ovulation. Baillieres Clin Obstet 
Gynaecol 1990; 4:419-439.

[140] Frisch RE, McArthur JW. Menstrual cycles: fatness as a determinant of minimum weight for height necessary for their maintenance or onset. Science 1974; 185:949-951.

[141] Rozeboom DW, Pettigrew JE, Moser RL, Cornelius SG, El Kandelgy SM. Influence of gilt age and body composition at first breeding on sow reproductive performance and longevity. J Anim Sci 1996; 74:138-150.

[142] Young LG, King GJ, Shaw J, Quinton M, Walton JS, McMillan I. Interrelationships among age, body weight, backfat and lactation feed intake with reproductive performance and longevity of sows. Can J Anim Sci 1991; 71:567-575.

[143] Young LG, King GJ, Walton JS, Mcmillan I, Klevorick M. Age, Weight, backfat and time of mating effects on performance of gilts. Can J Anim Sci 1990; 481:469-481.

[144] Hutchens LK, Hintz RL, Johnson RK. Genetic and phenotypic relationships between pubertal and growth characteristics of gilts. J Anim Sci 1981; 53:946-951.

[145] Tummaruk P, Tantasuparuk W, Techakumphu M, Kunavongkrit A. Age, body weight and backfat thickness at first observed oestrus in crossbred LandracexYorkshire gilts, seasonal variations and their influence on subsequence reproductive performance. Anim Reprod Sci 2007; 99:167-181.

[146] Tummaruk P, Lundeheim N, Einarsson S, Dalin AM. Effect of birth litter size, birth parity number, growth rate, backfat thickness and age at first mating of gilts on their reproductive performance as sows. Anim Reprod Sci 2001; 66:225-237.

[147] Zhuo Y, Zhou D, Che L, Fang Z, Lin Y, Wu D. Feeding prepubescent gilts a high-fat diet induces molecular changes in the hypothalamus-pituitary-gonadal axis and predicts early timing of puberty. Nutrition 2014; 30:890-896. 
[148] Newton EA, Mahan DC. Effect of Feed-Intake During Late Development on Pubertal Onset and Resulting Body-Composition in Crossbred Gilts. J Anim Sci 1992; 70:37743780 .

[149] Kummer R, Bernardi M, Schenkel A, Amaral Filha W, Wentz I, Bortolozzo F. Reproductive performance of gilts with similar age but with different growth rate at the onset of puberty stimulation. Reprod Domest Anim 2009; 44:255-259.

[150] Tummaruk P, Tantasuparuk W, Techakumphu M, Kunavongkrit A. The association between growth rate, body weight, backfat thickness and age at first observed oestrus in crossbred Landrace x Yorkshire gilts. Anim Reprod Sci 2009; 110:108-122.

[151] Friend DW. Effect of dietary energy and protein on age and weight at puberty of gilt. J Anim Sci 1977; 44:601-607.

[152] Patterson JL, Ball RO, Willis HJ, Aherne FX, Foxcroft GR. The effect of lean growth rate on puberty attainment in gilts. J Anim Sci 2002; 80:1299-1310.

[153] Rauw WM, Kanis E, Noordhuizen Stassen EN, Grommers FJ. Undesirable side effects of selection for high production efficiency in farm animals: a review. Livest Prod Sci 1998;

$56: 15$.

[154] Sterning M, Rydhmer L, Eliasson-Selling L. Relationships between age at puberty and interval from weaning to estrus and between estrus signs at puberty and after the first weaning in pigs. J Anim Sci 1998; 76:353-359.

[155] Zhang Y, Proenca R, Maffei M, Barone M, Leopold L, Friedman JM. Positional cloning of the mouse obese gene and its human homologue. Nature $1994 ; 372: 425-432$.

[156] White DW, Kuropatwinski KK, Devos R, Baumann H, Tartaglia LA. Leptin receptor (OB-R) signaling. Cytoplasmic domain mutational analysis and evidence for receptor 
homo-oligomerization. J Biol Chem 1997; 272:4065-71.

[157] Tartaglia LA. The leptin receptor*. J Biol Chem 1997; 272:6093-6096.

[158] Park HK, Ahima RS. Physiology of leptin: energy homeostasis, neuroendocrine function and metabolism. Metabolism 2015; 64:24-34.

[159] Tartaglia LA, Dembski M, Weng X, Deng N, Culpepper J, Devos R, Richards GJ, Campfield LA, Clark FT, Deeds J, Muir C, Sanker S, et al. Identification and expression cloning of a leptin receptor, OB-R. Cell 1995; 83:1263-1271.

[160] Frisch RE, Wyshak G, Vincent L. Delayed menarche and amenorrhea in ballet dancers. N Engl J Med 1980; 303:17-19.

[161] Ahima RS, Dushay J, Flier SN, Prabakaran D, Flier JS. Leptin accelerates the onset of puberty in normal female mice. J Clin Invest 1997; 99:391-395.

[162] Chehab FF, Lim ME, Lu R. Correction of the sterility defect in homozygous obese female mice by treatment with the human recombinant leptin. Nat Genet 1996; 12:318-320.

[163] Lin J, Barb CR, Matteri RL, Kraeling RR, Chen X, Meinersmann RJ, Rampacek GB. Long form leptin receptor mRNA expression in the brain, pituitary, and other tissues in the pig. Domest Anim Endocrinol 2000; 19:53-61.

[164] Dyer CJ, Simmons JM, Matteri RL, Keisler DH. Leptin receptor mRNA is expressed in ewe anterior pituitary and adipose tissues and is differentially expressed in hypothalamic regions of well-fed and feed-restricted ewes. Domest Anim Endocrinol 1997; 14:119-128.

[165] Zamorano PL, Mahesh VB, De Sevilla LM, Chorich LP, Bhat GK, Brann DW. Expression and localization of the leptin receptor in endocrine and neuroendocrine tissues of the rat. Neuroendocrinology 1997; 65:223-228.

[166] Mercer JG, Hoggard N, Williams LM, Lawrence CB, Hannah LT, Trayhurn P. 
Localization of leptin receptor mRNA and the long form splice variant $(\mathrm{Ob}-\mathrm{Rb})$ in mouse hypothalamus and adjacent brain regions by in situ hybridization. FEBS Lett 1996; $387: 113-116$.

[167] Cravo RM, Margatho LO, Osborne-Lawrence S, Donato J, Atkin S, Bookout AL, Rovinsky S, Frazão R, Lee CE, Gautron L, Zigman JM, Elias CF, et al. Characterization of Kiss1 neurons using transgenic mouse models. Neuroscience 2011; 173:37-56.

[168] True C, Kirigiti MA, Kievit P, Grove KL, Smith MS. Leptin is not the critical signal for kisspeptin or luteinising hormone restoration during exit from negative energy balance. $\mathbf{J}$ Neuroendocrinol 2011; 23:1099-112.

[169] Donato J, Cravo RM, Frazão R, Gautron L, Scott MM, Lachey J, Castro IA, Margatho LO, Lee S, Lee C, Richardson JA, Friedman J, et al. Leptin's effect on puberty in mice is relayed by the ventral premammillary nucleus and does not require signaling in Kiss1 neurons. J Clin Invest 2011; 121:355-68.

[170] Smith JT, Acohido B V., Clifton DK, Steiner RA. KiSS-1 neurones are direct targets for leptin in the ob/ob mouse. J Neuroendocrinol 2006; 18:298-303.

[171] Qiu J, Fang Y, Bosch MA, Rønnekleiv OK, Kelly MJ. Guinea pig kisspeptin neurons are depolarized by leptin via activation of TRPC channels. Endocrinology 2011; 152:150314.

[172] Czaja K, Kraeling RR, Barb CR. Are hypothalamic neurons transsynaptically connected to porcine adipose tissue? Biochem Biophys Res Commun 2003; 311:482-485.

[173] Elias CF, Purohit D. Leptin signaling and circuits in puberty and fertility. Cell Mol Life Sci 2013; 70:841-862.

[174] Cheung CC, Thornton JE, Nurani SD, Clifton DK, Steiner RA. A reassessment of leptin's 
role in triggering the onset of puberty in the rat and mouse. Neuroendocrinology 2001; 74:12-21.

[175] Barker-Gibb ML, Sahu A, Pohl CR, Plant TM. Elevating circulating leptin in prepubertal male rhesus monkeys (Macaca mulatta) does not elicit precocious gonadotropin-releasing hormone Release, Assessed Indirectly. J Clin Endocrinol Metab 2002; 87:4976-4983.

[176] Wilson ME, Fisher J, Chikazawa K, Yoda R, Legendre A, Mook D, Gould KG. Leptin administration increases nocturnal concentrations of luteinizing hormone and growth hormone in juvenile female rhesus monkeys. J Clin Endocrinol Metab 2003; 88:48744883.

[177] Suter KJ, Pohl CR, Wilson ME. Circulating concentrations of nocturnal leptin, growth hormone, and insulin-like growth factor-I increase before the onset of puberty in agonadal male monkeys: Potential Signals for the Initiation of Puberty. J Clin Endocrinol Metab 2000; 85:808-814.

[178] Gruaz NM, Lalaoui M, Pierroz DD, Englaro P, Sizonenko PC, Blum WF, Aubert ML. Chronic administration of leptin into the lateral ventricle induces sexual maturation in severely food-restricted female rats. J Neuroendocrinol 1998; 10:627-633.

[179] Henry BA, Goding JW, Tilbrook AJ, Dunshea FR, Clarke IJ. Intracerebroventricular infusion of leptin elevates the secretion of luteinising hormone without affecting food intake in long-term food-restricted sheep, but increases growth hormone irrespective of bodyweight. J Endocrinol 2001; 168:67-77.

[180] Henry BA, Goding JW, Alexander WS, Tilbrook AJ, Canny BJ, Dunshea F, Rao A, Mansell A, Clarke IJ. Central administration of leptin to ovariectomized ewes inhibits food intake without affecting the secretion of hormones from the pituitary gland: Evidence 
for a dissociation of effects on appetite and neuroendocrine function. Endocrinology 1999; 140:1175-1182.

[181] Qian H, Barb CR, Compton MM, Hausman GJ, Azain MJ, Kraeling RR, Baile CA. Leptin mRNA expression and serum leptin concentrations as influenced by age, weight, and estradiol in pigs. Domest Anim Endocrinol 1999; 16:135-143.

[182] Signoret J. Action de la progesterone sur le comportement d'oestrus induit par le benzoate d'oestradiol chez la Truie ovariec- tomisre, Ann. Ann Biol Biochim Biophys 1969; 9:361368.

[183] Soede NM, Helmond FA, Kemp B. Periovulatory profiles of oestradiol, LH and progesterone in relation to oestrus and embryo mortality in multiparous sows using transrectal ultrasonography to detect ovulation. J Reprod Fertil 1994; 101:633-641.

[184] Lüking Jayes FC, Britt JH, Esbenshade KL. Role of gonadotropin-releasing hormone pulse frequency in differential regulation of gonadotropins in the gilt. Biol Reprod 1997; 56:1012-1019.

[185] Knox R V., Vatzias G, Naber CH, Zimmerman DR. Plasma gonadotropins and ovarian hormones during the estrous cycle in high compared to low ovulation rate gilts. J Anim Sci 2003; 81:249.

[186] Guthrie HD, Bolt DJ. Changes in plasma follicle-stimulating hormone, luteinizing hormone, estrogen and progesterone during growth of ovulatory follicles in the pig. Domest Anim Endocrinol 1990; 7:83-91.

[187] Erickson GF, Hsueh AJ. Stimulation of aromatase activity by follicle stimulating hormone in rat granulosa cells in vivo and in vitro. Endocrinology 1978; 102:1275-1282.

[188] Goodman RL, Karsch FJ. Pulsatile secretion of luteinizing hormone: differential 
suppression by ovarian steroids. Endocrinology 1980; 107:1289.

[189] Almond GW, Dial GD. Estradiol feedback inhibition of luteinizing hormone concentrations in the anestrous sow. J Anim Sci 1990; 68:1077-1086.

[190] Foxcroft GR, Elsaesser F, Stickney K, Haynes NB, Back HL. Ovarian oestrogendependent maturation of the LH/FSH surge mechanism during prepubertal development in the gilt. J Endocrinol 1984; 101:371-380.

[191] Stevenson J., Cox N., Britt H. Role of the ovary in controlling luteinizing hormone, follicle stimulating hormone and prolactin secretion during and after lactation in pigs $1981 ; 24: 341-53$.

[192] Karsch FJ, Foster DL. Sexual differentiation of the mechanism controlling the preovulatory discharge of luteinizing hormone in sheep. Endocrinology 1975; 97:373379.

[193] Krege JH, Hodgin JB, Couse JF, Enmark E, Warner M, Mahler JF, Sar M, Korach KS, Gustafsson JA, Smithies O. Generation and reproductive phenotypes of mice lacking estrogen receptor beta. Proc Natl Acad Sci U S A 1998; 95:15677-15682.

[194] Dutt RH, Casida LE. Alteration of the estrual cycle in sheep by use of progesterone and its effect upon subsequent ovulation and fertility. Endocrinology 1948; 43:208-217.

[195] Goodman RL, Bittman EL, Foster DL, Karsch FJ. The endocrine basis of the synergistic suppression of luteinizing hormone by estradiol and progesterone. Endocrinology 1981; 109:1414-1417.

[196] Baker LN, Ulberg LC, Grummer RH, Casida E. Inhibition of heat by progesterone and its effect on subsequent fertility in gilts 1954:648-657.

[197] Moore NW, Robinson TJ. The behavioural and vaginal response of the spayed ewe to 
oestrogen injected at various times relative to the injection of progesterone. J Endocrinol $1957 ; 15: 360-365$.

[198] Blache D, Fabre-Nys C, Venier G. Inhibition of sexual behaviour and the luteinizing hormone surge by intracerebral progesterone implants in the female sheep. Brain Res $1996 ; 741: 117-122$.

[199] Clarke IJ, Cummins JT. Direct pituitary effects of estrogen and progesterone on gonadotropin secretion in the ovariectomized ewe. Neuroendocrinology 1984; 39:267274.

[200] Stephens SBZ, Tolson KP, Rouse ML, Poling MC, Hashimoto-Partyka MK, Mellon PL, Kauffman AS. Absent progesterone signaling in kisspeptin neurons disrupts the LH surge and impairs fertility in female mice. Endocrinology 2015; 156:3091-3097.

[201] Hrabovszky E, Sipos MT, Molnár CS, Ciofi P, Borsay BÁ, Gergely P, Herczeg L, Bloom SR, Ghatei MA, Dhillo WS, Liposits Z. Low degree of overlap between kisspeptin, neurokinin $\mathrm{B}$, and dynorphin immunoreactivities in the infundibular nucleus of young male human subjects challenges the KNDy neuron concept. Endocrinology 2012; $153: 4978-4989$.

[202] Ruka KA, Burger LL, Moenter SM. Regulation of arcuate neurons coexpressing kisspeptin, neurokinin b, and dynorphin by modulators of neurokinin 3 and k-opioid receptors in adult male mice. Endocrinology 2013; 154:2761-2771.

[203] Lee J-H, Miele ME, Hicks DJ, Phillips KK, Trent JM, Weissman BE, Welch DR. KiSS-1, a novel human malignant melanoma metastasis-suppressor gene. JNCI J Natl Cancer Inst 1996; 88:1731-1737.

[204] Tena-Sempere M. GPR54 and kisspeptin in reproduction. Hum Reprod Update 2006; 
$12: 631-639$.

[205] Lee DK, Nguyen T, O’Neill GP, Cheng R, Liu Y, Howard AD, Coulombe N, Tan CP, Tang-Nguyen A-T, George SR, O’Dowd BF. Discovery of a receptor related to the galanin receptors. FEBS Lett 1999; 446:103-107.

[206] Muir AI, Chamberlain L, Elshourbagy NA, Michalovich D, Moore DJ, Calamari A, Szekeres PG, Sarau HM, Chambers JK, Murdock P, Steplewski K, Shabon U, et al. AXOR12, a novel human G protein-coupled receptor, activated by the peptide KiSS-1. J Biol Chem 2001; 276:28969-75.

[207] Bilban M, Ghaffari-Tabrizi N, Hintermann E, Bauer S, Molzer S, Zoratti C, Malli R, Sharabi A, Hiden U, Graier W, Knöfler M, Andreae F, et al. Kisspeptin-10, a KiSS1/metastin-derived decapeptide, is a physiological invasion inhibitor of primary human trophoblasts. J Cell Sci 2004; 117:1319-28.

[208] Kotani M, Detheux M, Vandenbogaerde A, Communi D, Vanderwinden JM, Le Poul E, Brézillon S, Tyldesley R, Suarez-Huerta N, Vandeput F, Blanpain C, Schiffmann SN, et al. The metastasis suppressor gene KiSS-1 encodes kisspeptins, the natural ligands of the orphan G protein-coupled receptor GPR54. J Biol Chem 2001; 276:34631-6.

[209] Richard N, Corvaisier S, Camacho E, Kottler M-L. KiSS-1 and GPR54 at the pituitary level: Overview and recent insights. Peptides 2009; 30:123-129.

[210] Kauffman AS, Park JH, McPhie-Lalmansingh AA, Gottsch ML, Bodo C, Hohmann JG, Pavlova MN, Rohde AD, Clifton DK, Steiner RA, Rissman EF. The kisspeptin receptor GPR54 is required for sexual differentiation of the brain and behavior. J Neurosci 2007; $27: 8826-8835$.

[211] Navarro VM, Castellano JM, Fernández-Fernández R, Barreiro ML, Roa J, Sanchez- 
Criado JE, Aguilar E, Dieguez C, Pinilla L, Tena-Sempere M. Developmental and hormonally regulated messenger ribonucleic acid expression of KiSS-1 and its putative receptor, GPR54, in rat hypothalamus and potent luteinizing hormone-releasing activity of KiSS-1 peptide. Endocrinology 2004; 145:4565-4574.

[212] Shahab M, Mastronardi C, Seminara SB, Crowley WF, Ojeda SR, Plant TM. Increased hypothalamic GPR54 signaling: A potential mechanism for initiation of puberty in primates. Proc Natl Acad Sci 2005; 102:2129-2134.

[213] Clarkson J, Herbison AE. Postnatal development of kisspeptin neurons in mouse hypothalamus; sexual dimorphism and projections to gonadotropin-releasing hormone neurons. Endocrinology 2006; 147:5817-5825.

[214] Ramaswamy S, Guerriero KA, Gibbs RB, Plant TM. Structural interactions between kisspeptin and GnRH neurons in the mediobasal hypothalamus of the male rhesus monkey (Macaca mulatta) as revealed by double immunofluorescence and confocal microscopy. Endocrinology 2008; 149:4387-4395.

[215] Han S-K, Gottsch ML, Lee KJ, Popa SM, Smith JT, Jakawich SK, Clifton DK, Steiner RA, Herbison AE. Activation of gonadotropin-releasing hormone neurons by kisspeptin as a neuroendocrine switch for the onset of puberty. J Neurosci 2005; 25:11349-11356.

[216] Herbison AE, De Tassigny XDA, Doran J, Colledge WH. Distribution and postnatal development of GPR54 gene expression in mouse brain and gonadotropin-releasing hormone neurons. Endocrinology 2010; 151:312-321.

[217] Li XF, Kinsey-Jones JS, Cheng Y, Knox AMI, Lin Y, Petrou NA, Roseweir A, Lightman SL, Milligan SR, Millar RP, O’Byrne KT. Kisspeptin signaling in the hypothalamic arcuate nucleus regulates GnRH pulse generator frequency in the rat. PLoS One 2009; 
4:e8334.

[218] Nestor CC, Qiu J, Padilla SL, Zhang C, Bosch MA, Fan W, Aicher SA, Palmiter RD, Rønnekleiv OK, Kelly MJ. Optogenetic stimulation of arcuate nucleus kiss1 neurons reveals a steroid-dependent glutamatergic input to POMC and AgRP neurons in male mice. Mol Endocrinol 2016; 30:630-644.

[219] Mcdonald JK, Lumpkin MD, Samson WK, Mccann SM. Neuropeptide Y affects secretion of luteinizing hormone and growth hormone in ovariectomized rats. Med Sci 1985; $82: 561-564$.

[220] Stanley SA, Small CJ, Kim MS, Heath MM, Seal LJ, Russell SH, Ghatei MA, Bloom SR. agouti related peptide (AgRP) Stimulates the hypothalamo pituitary gonadal Axis in Vivo \& in Vitro in male rats. Endocrinology 1999; 140:5459-5462.

[221] Wise PM, Scarbrough K, Weiland NG, Larson GH. Diurnal pattern of proopiomelanocortin gene expression in the arcuate nucleus of proestrous, ovariectomized, and steroid- treated rats: a possible role in cyclic luteinizing hormone secretion. Mol Endocrinol 1990; 4:886-892.

[222] McShane TM, Petersen SL, McCrone S, Keisler DH. Influence of food restriction on neuropeptide-Y, proopiomelanocortin, and luteinizing hormone-releasing hormone gene expression in sheep hypothalami. Biol Reprod 1993; 49:831-839.

[223] Herbison AE. Estrogen positive feedback to gonadotropin-releasing hormone ( $\mathrm{GnRH})$ neurons in the rodent: The case for the rostral periventricular area of the third ventricle (RP3V). Brain Res Rev 2008; 57:277-287.

[224] Irwig MS, Fraley GS, Smith JT, Acohido B V., Popa SM, Cunningham MJ, Gottsch ML, Clifton DK, Steiner RA. Kisspeptin activation of gonadotropin releasing hormone neurons 
and regulation of KiSS-1 mRNA in the male rat. Neuroendocrinology 2004; 80:264-272.

[225] Thompson EL, Patterson M, Murphy KG, Smith KL, Dhillo WS, Todd JF, Ghatei MA, Bloom SR. Central and peripheral administration of kisspeptin-10 stimulates the hypothalamic-pituitary-gonadal axis. J Neuroendocrinol 2004; 16:850-858.

[226] Matsui H, Asami T. Effects and therapeutic potentials of kisspeptin analogs: Regulation of the hypothalamic-pituitary-gonadal axis. Neuroendocrinology 2014; 99:49-60.

[227] Barb CR, Hausman GJ, Lents CA. Energy metabolism and leptin: Effects on neuroendocrine regulation of reproduction in the gilt and sow. Reprod Domest Anim 2008.

[228] Matsui H, Takatsu Y, Kumano S, Matsumoto H, Ohtaki T. Peripheral administration of metastin induces marked gonadotropin release and ovulation in the rat. Biochem Biophys Res Commun 2004; 320:383-388.

[229] Tovar S, Vázquez MJ, Navarro VM, Fernández-Fernández R, Castellano JM, Vigo E, Roa J, Casanueva FF, Aguilar E, Pinilla L, Dieguez C, Tena-Sempere M. Effects of single or repeated intravenous administration of kisspeptin upon dynamic $\mathrm{LH}$ secretion in conscious male rats. Endocrinology 2006; 147:2696-2704.

[230] Tena-Sempere M. The roles of kisspeptins and G protein-coupled receptor-54 in pubertal development. Curr Opin Pediatr 2006; 18:442-7.

[231] Rance NE, Young WS. Hypertrophy and increased gene expression of neurons containing neurokinin-b and substance-p messenger ribonucleic acids in the hypothalami of postmenopausal women. Endocrinology 1991; 128:2239-2247.

[232] Sahu A, Kalra SP. Effects of tachykinins in female rats: potent inhibitory action of neuropeptide K. Endocrinology 1992; 130:1571-77. 
[233] Rance NE, Bruce TR. Neurokinin B gene expression is increased in the arcuate nucleus of ovariectomized rats. Neuroendocrinology 1994; 60:337-345.

[234] Angell AE, Steiner RA. TACkling NKB's role in puberty. Endocrinology 2015; 156:1207-1209.

[235] Noritake K, Matsuoka T, Ohsawa T, Shimomura K, Sanbuissho A, UENOYAMA Y, Maeda K, Tsukamura H. Involvement of neurokinin receptors in the control of pulsatile luteinizing hormone secretion in rats. J Reprod Dev 2011; 57:409-415.

[236] Francou B, Bouligand J, Voican A, Amazit L, Trabado S, Fagart J, Meduri G, BraillyTabard S, Chanson P, Lecomte P, Guiochon-Mantel A, Young J. Normosmic congenital hypogonadotropic hypogonadism due to TAC3/TACR3 mutations: characterization of neuroendocrine phenotypes and novel mutations. PLoS One 2011; 6:e25614.

[237] Yang JJ, Caligioni CS, Chan YM, Seminara SB. Uncovering novel reproductive defects in neurokinin B receptor null mice: Closing the gap between mice and men. Endocrinology $2012 ; 153: 1498-1508$.

[238] Goubillon ML, Forsdike RA, Robinson JE, Ciofi P, Caraty A, Herbison AE. Identification of neurokinin B-expressing neurons as a highly estrogen-receptive, sexually dimorphic cell group in the ovine arcuate nucleus. Endocrinology 2000; 141:4218-4225.

[239] Jakimiuk A, Podlasz P, Chmielewska-Krzesinska M, Wasowicz K. Characterisation, localisation and expression of porcine TACR1, TACR2 and TACR3 genes. Vet Med (Praha) 2017; 62:443-455.

[240] Dellovade TL, Merchenthaler I. Estrogen regulation of neurokinin B gene expression in the mouse arcuate nucleus Is mediated by estrogen receptor $\alpha$. Endocrinology 2004; 145:736-742. 
[241] Krajewski SJ, Anderson MJ, Iles-Shih L, Chen KJ, Urbanski HF, Rance NE. Morphologic evidence that neurokinin B modulates gonadotropin-releasing hormone secretion via neurokinin 3 receptors in the rat median eminence. J Comp Neurol 2005; 489:372-386.

[242] Grachev P, Millar RP, O’Byrne KT. The role of neurokinin B signalling in reproductive neuroendocrinology. Neuroendocrinology 2014; 99:7-17.

[243] Ahn T, Fergani C, Coolen LM, Padmanabhan V, Lehman MN. Prenatal testosterone excess decreases neurokinin 3 receptor immunoreactivity within the arcuate nucleus KNDy cell population. J Neuroendocrinol 2015; 27:100-110.

[244] Amstalden M, Coolen LM, Hemmerle AM, Billings HJ, Connors JM, Goodman RL, Lehman MN. Neurokinin 3 receptor immunoreactivity in the septal region, preoptic area and hypothalamus of the female sheep: Colocalisation in neurokinin B cells of the arcuate nucleus but not in gonadotrophin-releasing hormone neurones. J Neuroendocrinol 2010; 22:1-12.

[245] Sandoval-Guzmán T, E. Rance N. Central injection of senktide, an NK 3 receptor agonist, or neuropeptide Y inhibits LH secretion and induces different patterns of Fos expression in the rat hypothalamus. Brain Res 2004; 1026:307-312.

[246] Porter KL, Hileman SM, Hardy SL, Nestor CC, Lehman MN, Goodman RL. neurokinin-3 receptor activation in the retrochiasmatic area is essential for the full pre-ovulatory luteinising hormone surge in ewes. J Neuroendocrinol 2014; 26:776-784.

[247] Grachev P, Porter KL, Coolen LM, McCosh RB, Connors JM, Hileman SM, Lehman MN, Goodman RL. Surge-Like luteinising hormone secretion induced by retrochiasmatic area NK3R activation is mediated primarily by arcuate kisspeptin neurones in the ewe. $\mathrm{J}$ Neuroendocrinol 2016; 28:1304-1314. 
[248] Horikawa S, Takai T, Toyosato M, Takahashi H, Noda M, Kakidani H, Kubo T, Hirose T, Inayama S, Hayashida H, Miyata T, Numa S. Isolation and structural organization of the human preproenkephalin B gene. Nature 1983; 306:611-614.

[249] Douglass J, McMurray CT, Garrettt JE, Adelman JP, Calavetta L. Characterization of the Rat Prodynorphin Gene. Mol Endocrinol 1989; 3:2070-2078.

[250] Sharifi N, Ament M, Brennan MB, Hochgeschwender U. Isolation and characterization of the mouse homolog of the preprodynorphin (Pdyn) gene. Neuropeptides 1999; 33:236238.

[251] Schwarzer C. 30 years of dynorphins - New insights on their functions in neuropsychiatric diseases. Pharmacol Ther 2009; 123:353-370.

[252] Yakovleva T, Bazov I, Cebers G, Marinova Z, Hara Y, Ahmed A, Vlaskovska M, Johansson B, Hochgeschwender U, Singh IN, Bruce-Keller AJ, Hurd YL, et al. Prodynorphin storage and processing in axon terminals and dendrites. FASEB J 2006; 20:2124-2126.

[253] Khachaturian H, Lewis ME, Haber SN, Houghten RA, Akil H, Watson SJ. Prodynorphin peptide immunocytochemistry in rhesus monkey brain. Peptides 1985; 6:155-166.

[254] Abe J, Okamura H, Kitamura T, Ibata Y, Minamino N, Matsuo H, Paull WK. Immunocytochemical demonstration of dynorphin(PH-8P)-like immunoreactive elements in the human hypothalamus. J Comp Neurol 1988; 276:508-513.

[255] Sannella MI, Petersen SL. Dual label in situ hybridization studies provide evidence that luteinizing hormone-releasing hormone neurons do not synthesize messenger ribonucleic acid for $\mu, \kappa$, or $\delta$ opiate receptors 1. Endocrinology 1997; 138:1667-1672.

[256] Marson L, Lauterio TJ, Della-Fera M-A, Baile CA. Immunohistochemical distribution of 
cholecystokinin, dynorphin A and Met-enkephalin neurons in sheep hypothalamus. Neurosci Lett 1987; 81:35-40.

[257] Sliwowska JH, Billings HJ, Goodman RL, Coolen LM, Lehman MN. The Premammillary hypothalamic area of the ewe: anatomical characterization of a melatonin target area mediating seasonal reproduction. Biol Reprod 2004; 70:1768-1775.

[258] Foradori CD, Goodman RL, Lehman MN. Distribution of preprodynorphin mRNA and dynorphin-A immunoreactivity in the sheep preoptic area and hypothalamus. Neuroscience 2005; 130:409-418.

[259] Iqbal J, Henry B., Pompolo S, Rao A, Clarke I. Long-term alteration in bodyweight and food restriction does not affect the gene expression of either preproorexin or prodynorphin in the sheep. Neuroscience $2003 ; 118: 217-226$.

[260] Baile CA, McLaughlin CL, Buonomo FC, Lauterio TJ, Marson L, Della-Fera MA. Opioid peptides and the control of feeding in sheep. Fed Proc 1987; 46:173-7.

[261] Shimizu H, Shimomura Y, Negishi M, Kobayashi I, Kobayashi S. Dynorphin A (1-13), microinjected into the preoptic area, stimulates water intake in rats. Life Sci 1989; 45:2530.

[262] Young WS, Lightman SL. Chronic stress elevates enkephalin expression in the rat paraventricular and supraoptic nuclei. Mol Brain Res 1992; 13:111-117.

[263] Kim E-M, Kotz CM, Welch CC, Grace MK, Billington CJ, Levine AS. Lactation decreases mRNA levels of opioid peptides in the arcuate nucleus of the rat. Brain Res 1997; 769:303-308.

[264] Clarke S, Zimmer A, Zimmer A., Hill R., Kitchen I. Region selective up-regulation of $\mu$-, $\delta$ - and $\kappa$-opioid receptors but not opioid receptor-like 1 receptors in the brains of 
enkephalin and dynorphin knockout mice. Neuroscience 2003; 122:479-489.

[265] Sharifi N, Diehl N, Yaswen L, Brennan MB, Hochgeschwender U. Generation of dynorphin knockout mice. Mol Brain Res 2001; 86:70-75.

[266] Foradori CD, Coolen LM, Fitzgerald ME, Skinner DC, Goodman RL, Lehman MN. Colocalization of progesterone receptors in parvicellular dynorphin neurons of the ovine preoptic area and hypothalamus. Endocrinology 2002; 143:4366-4374.

[267] Goodman RL, Coolen LM, Anderson GM, Hardy SL, Valent M, Connors JM, Fitzgerald ME, Lehman MN. Evidence that dynorphin plays a major role in mediating progesterone negative feedback on gonadotropin-releasing hormone neurons in sheep. Endocrinology 2004; 145:2959-2967.

[268] Goodman RL, Holaskova I, Nestor CC, Connors JM, Billings HJ, Valent M, Lehman MN, Hileman SM. Evidence that the arcuate nucleus is an important site of progesterone negative feedback in the ewe. Endocrinology 2011; 152:3451-3460.

[269] Foradori CD, Goodman RL, Adams VL, Valent M, Lehman MN. Progesterone increases dynorphin A concentrations in cerebrospinal fluid, and preprodynorphin messenger ribonucleic acid levels in a subset of dynorphin neurons in the sheep. Endocrinology 2005; 146:1835-1842.

[270] Nakahara T, Uenoyama Y, Iwase A, Oishi S, Nakamura S, Minabe S, Watanabe Y, Deura C, Noguchi T, Fujii N, Kikkawa F, Maeda K, et al. Chronic peripheral administration of kappa-opioid receptor antagonist advances puberty onset associated with acceleration of pulsatile luteinizing hormone secretion in female rats. J Reprod Dev 2013; 59:479-84.

[271] Lehman MN, Coolen LM, Goodman RL. Minireview: Kisspeptin/neurokinin B/dynorphin (KNDy) cells of the arcuate nucleus: A central node in the control of gonadotropin- 
releasing hormone secretion. Endocrinology 2010; 151:3479-3489.

[272] Fass. Guide for the care and use of agricultural animals in research and teaching. 2010.

[273] Nutrient Requirements of Swine 2012.

[274] Leary S, Underwood W, Anthony R, Cartner S. AVMA guidelines for the euthanasia of Animals: 2013 Edition. 2013.

[275] Knox R V. Current and future reproductive technologies and world food production 2014; 752.

[276] Lunney JK. Advances in swine biomedical model genomics. Int J Biol Sci 2007; 3:179_ 184.

[277] Smith JT, Cunningham MJ, Rissman EF, Clifton DK, Steiner RA. Regulation of Kiss1 gene expression in the brain of the female mouse. Endocrinology $2005 ; 146: 3686-3692$.

[278] Skinner DC, Caraty A, Allingham R. Unmasking the progesterone receptor in the preoptic area and hypothalamus of the ewe: no colocalization with gonadotropin-releasing neurons. Endocrinology 2001; 142:573-579.

[279] Alçin E, Sahu A, Ramaswamy S, Hutz ED, Keen KL, Terasawa E, Bethea CL, Plant TM. Ovarian regulation of kisspeptin neurones in the arcuate nucleus of the rhesus monkey (Macaca mulatta). J Neuroendocrinol 2013; 25:488-496.

[280] Roa J, Vigo E, Castellano JM, Navarro VM, Fernández-Fernández R, Casanueva FF, Dieguez C, Aguilar E, Pinilla L, Tena-Sempere M. Hypothalamic expression of KiSS-1 system and gonadotropin-releasing effects of kisspeptin in different reproductive states of the female rat. Endocrinology 2006; 147:2864-2878.

[281] Skinner DC, Evans NP, Delaleu B, Goodman RL, Bouchard P, Caraty A. The negative feedback actions of progesterone on gonadotropin- releasing hormone secretion are 
transduced by the classical progesterone receptor. Physiology 1998; 95:10978-10983.

[282] Smith JT, Clay CM, Caraty A, Clarke IJ. KiSS-1 messenger ribonucleic acid expression in the hypothalamus of the ewe is regulated by sex steroids and season. Endocrinology 2007; 148:1150-1157.

[283] Paterson AM, Martin GB. Induction of puberty in gilts 3. Ovulation, plasma oestradiol and progesterone in gilts injected with pregnant mare's serum gonadotrophin and human chorionic gonadotrophin. Anim Prod 1981; 32:55-59.

[284] Richard Barb C, Rampacek GB, Kraeling RR, Estienne MJ, Taras E, Estienne CE, Scott Whisnant C. Absence of brain opioid peptide modulation of luteinizing hormone secretion in the prepubertal gilt. Biol Reprod 1988; 39:603-609.

[285] Romano GJ, Krust A, Pfaff DW. Expression and estrogen regulation of progesterone receptor mRNA in neurons of the mediobasal hypothalamus: An in situ hybridization study. Mol Endocrinol 1989; 3:1295-1300.

[286] Kraus WL. Identification of multiple, widely spaced estrogen-responsive regions in the rat progesterone receptor gene. Mol Endocrinol 1994; 8:952-969.

[287] Micevych P, Sinchak K, Mills RH, Tao L, LaPolt P, Lu JKH. The luteinizing hormone surge is preceded by an estrogen-induced increase of hypothalamic progesterone in ovariectomized and adrenalectomized rats. Neuroendocrinology 2003; 78:29-35.

[288] Leavitt WW, Chen TJ, Allen TC, O'Neal Johnston J. Regulation of progesterone receptor formation by estrogen action. Ann N Y Acad Sci 1977; 286:210-225.

[289] Skinner DC, Evans NP, Delaleu B, Goodman RL, Bouchard P, Caraty A. The negative feedback actions of progesterone on gonadotropin- releasing hormone secretion are transduced by the classical progesterone receptor. Physiology 1998; 95:10978-10983. 